\title{
Latin American Influences on Selected Piano Pieces by Louis Moreau Gottschalk and Darius Milhaud
}

\author{
Hyejeong Seong
}

hyseong@mix.wvu.edu

Follow this and additional works at: https://researchrepository.wvu.edu/etd

Part of the Music Performance Commons

\section{Recommended Citation}

Seong, Hyejeong, "Latin American Influences on Selected Piano Pieces by Louis Moreau Gottschalk and Darius Milhaud" (2019). Graduate Theses, Dissertations, and Problem Reports. 7429.

https://researchrepository.wvu.edu/etd/7429

This Dissertation is protected by copyright and/or related rights. It has been brought to you by the The Research Repository @ WVU with permission from the rights-holder(s). You are free to use this Dissertation in any way that is permitted by the copyright and related rights legislation that applies to your use. For other uses you must obtain permission from the rights-holder(s) directly, unless additional rights are indicated by a Creative Commons license in the record and/ or on the work itself. This Dissertation has been accepted for inclusion in WVU Graduate Theses, Dissertations, and Problem Reports collection by an authorized administrator of The Research Repository @ WVU.

For more information, please contact researchrepository@mail.wvu.edu. 


\title{
LATIN AMERICAN INFLUENCES ON SELECTED PIANO PIECES BY LOUIS MOREAU GOTTSCHALK AND DARIUS MILHAUD
}

\author{
Hyejeong Seong
}

A Doctoral Research Project submitted to the College of Creative Arts at

West Virginia University In partial fulfillment of the requirements for the degree of Doctor of Musical Arts in Piano Performance

Peter Amstutz, D.M.A., Chair and Research Advisor Cynthia Anderson, M.M.

James Miltenberger, D.M.A.

William Haller, D.M.A.

J. Bernard Schultz, Ph.D.

School of Music

Morgantown, West Virginia 2019

Keywords: Louis Gottschalk, Darius Milhaud, Piano Works, Latin Influence (C) 2019 Hyejeong Seong 


\section{Abstract \\ Latin American Influences on Selected Piano Pieces \\ by Louis Moreau Gottschalk and Darius Milhaud}

\section{Hyejeong Seong}

This research document examines selected piano works by Louis Moreau Gottschalk (1829-1869) and Darius Milhaud (1892-1974) that are influenced by Latin American cultures. The paper traces the influence of Latin American music and the incorporation of characteristic melodic, harmonic, and rhythmic elements in the following compositions: Souvenir de Porto Rico, op. 31 (1857) and Souvenir de la Havane, op. 39 (1859) by Gottschalk; Saudades do Brasil, op. 67 (1920-1921) and Brasileira: Third movement of Scaramouche Suite, op. 165b (1937), for Two Pianos, by Milhaud.

After a brief introduction, the study reviews the existing related literature about this topic. Then, Chapters Three and Four discuss Gottschalk and Milhaud, respectively. The outline for each of these chapters features the respective composer's biography, compositional style, and list of works, along with an overview of the two selected works for each, with recommended pedagogical approaches. Then, Cuban and Brazilian influences on these two composers are discussed. Conclusion and selected bibliography follow. 


\title{
Table of Contents
}

\begin{abstract}
List of Musical Examples $\quad$ iv

List of Tables

Chapter 1. Introduction $\quad 1$

$\begin{array}{lll}\text { Chapter 2. } & \text { Related literature }\end{array}$

Chapter 3. Louis Moreau Gottschalk

Biography 13

Compositional Style of Piano Works 18

List of Piano works $\quad 22$

Piano Works influenced by Latin America
I. Souvenir de Porto Rico

II. Souvenir de la Havane $\quad 35$

Cuban Influences on Gottschalk 44
\end{abstract}

Chapter 4. Darius Milhaud

Biography 50

Compositional Style of Piano Works 55

List of Piano Works

Piano Works influenced by Latin America
I. Saudades do Brasil

Brazilian Influences on Milhaud $\quad 88$

$\begin{array}{lll}\text { Chapter 5. Conclusions } & 95\end{array}$

$\begin{array}{ll}\text { Selected Bibliography } & 97\end{array}$ 


\section{List of Musical Examples}

Examples

Example 3.1. Aguinaldo Si Me Dan Pasteles, mm.1-8. 26

Example 3.2. Louis Gottschalk, Souvenir de Porto Rico, Refrain, mm. 1-8. 28

Example 3.3. Louis Gottschalk, Souvenir de Porto Rico, Theme A, mm. 17-23. 28

Example 3.4. Louis Gottschalk, Souvenir de Porto Rico, Interlude material, mm. 49-58. 28

Example 3.5. Louis Gottschalk, Souvenir de Porto Rico, Transition, mm. 202-208. 29

Example 3.6. Louis Gottschalk, Souvenir de Porto Rico, Variation 1, mm. 33-40. 30

Example 3.7. Louis Gottschalk, Souvenir de Porto Rico, Variation 3, mm. 85-90. 31

Example 3.8. Tango, cinquillo, habanera, conga/tresillo rhythmic patterns. 32

Example 3.9. Louis Gottschalk, Souvenir de Porto Rico, Variation 2, mm. 59-64. 32

Example 3.10. Louis Gottschalk, Souvenir de Porto Rico, Variation 6, mm. 173-178. 33

Example 3.11. Louis Gottschalk, Souvenir de Porto Rico, Cross-over passage, mm. 117-122. 34

Example 3.12. Louis Gottschalk, Souvenir de Porto Rico, Octave passages, mm. 149-156. 34

Example 3.13. Louis Gottschalk, Souvenir de la Havane, Theme of prima, mm. 1-8. 37

Example 3.14. Louis Gottschalk, Souvenir de la Havane, Theme of Segunda, mm. 75-82. 37

Example 3.15. Louis Gottschalk, Souvenir de la Havane, Introduction, mm. 67-74. 38

Example 3.16. Louis Gottschalk, Souvenir de la Havane, Improvisation on the theme B, mm.

$\begin{array}{ll}139-154 . & 40\end{array}$

Example 3.17. Louis Gottschalk, Souvenir de la Havane, mm. 158-160. 42

Example 3.18. Louis Gottschalk, El cocoye, mm. 271-273. 42

Example 3.19. Manuel Saumell Robredo, Contradanza 'El Bazar.' 46 
Example 4.1. Darius Milhaud, Piano Suite, op. 8, no. 1, mm. 1-9. 57

Example 4.2. Darius Milhaud, Piano Suite, op. 8, no. 3, mm. 10-13. 58

Example 4.3. Darius Milhaud, Mazurka. $\quad 59$

Example 4.4. Darius Milhaud, Printemps, Book I, op. 25, no.2, mm. 4-9. 62

Example 4.5. Darius Milhaud, Printemps, Book I, op. 25, no.2, mm. 16-11. 62

Example 4.6. Darius Milhaud, Saudades do Brasil, Corcovado, mm. 1-14. 69

Example 4.7. Darius Milhaud, Saudades do Brasil, Sorocaba, mm. 1-4, 21-24. 70

Example 4.8. Igor Stravinsky, Petrouchka, Petrouchka's room, mm. 9-12. 71

Example 4.9. Darius Milhaud, Saudades do Brasil, Tijuca, mm. 1-9. 72

Example 4.10. Darius Milhaud, Saudades do Brasil, Copacabana, mm. 21-26. 72

Example 4.11. Darius Milhaud, Saudades do Brasil, Ipanema, mm. 1-5. 73

Example 4.12. Darius Milhaud, Saudades do Brasil, Botafoga, mm. 1-4. 74

Example 4.13. Darius Milhaud, Saudades do Brasil, Laranjeiras, mm. 1-4. 74

Example 4.14. Darius Milhaud, Saudades do Brasil, Paysandu, mm. 1-4. 74

Example 4.15. Darius Milhaud, Saudades do Brasil, Sumare, mm. 29-34. 75

Example 4.16. Darius Milhaud, Saudades do Brasil, Corcovado, mm. 1-4, 20-24. 76

Example 4.17. Darius Milhaud, Brasileira, Four themes. 81

Example 4.18. Darius Milhaud, Brasileira, Three primary rhythm types in Part A. 84

Example 4.19. Darius Milhaud, Brasileira, mm. 30-33. 85

Example 4.20. Darius Milhaud, Brasileira, Three primary rhythm types in Part C. 86

Example 4.21. Typical dance rhythms in Nazareth's music. 90

Example 4.22. Alexandre Levy, Schumanniana, op. 16, mm. 1-4. 92 


\section{List of Tables}

Table 3.1. Louis Gottschalk, Souvenir de Porto Rico, Formal Structure.

Table 3.2. Louis Gottschalk, Souvenir de Porto Rico, Harmonic progression, mm. 17-32. 30

Table 3.3. Louis Gottschalk, Souvenir de Porto Rico, Frequency of specific dynamic levels. 31

Table 3.4. Louis Gottschalk, Souvenir de la Havane, op. 39, Structure of the music. 35

Table 4.1. Darius Milhaud, Brasileira, Outline.

80 


\section{Chapter 1}

\section{Introduction}

This research document, "Latin American Influences on Selected Piano Pieces by Louis Moreau Gottschalk and Darius Milhaud," examines Latin American influences and provides a formal analysis of the following pieces:

- Souvenir de Porto Rico, op. 31 (1857), by Louis Moreau Gottschalk

- Souvenir de la Havane, op. 39 (1859), by Louis Moreau Gottschalk

- Saudades do Brasil, op. 67 (1920-1921), by Darius Milhaud

- Brasileira: Third movement of Scaramouche Suite, op. 165b (1937), for Two Pianos, by Darius Milhaud

Both Louis Moreau Gottschalk (1829-1869) and Darius Milhaud (1892-1974) were active musicians who earned fame in their mother countries, respectively the United States and France. Each composed many works within his own musical language, but also incorporated musical influences from other cultures, showing interest in new musical techniques from other countries. This research project examines how each composer was influenced by Latin American music and incorporated characteristic Latin melodic, harmonic, and rhythmic elements into his compositions.

Gottschalk and Milhaud make individual use of Latin American musical elements, because each brings his own cultural and musical perspective to his works and each interprets Latin American music differently. Elements of Caribbean and Brazilian folk music feature prominently in the works discussed in this paper. Chapters Three and Four discuss Gottschalk and Milhaud, 
respectively. The outline for each of these chapters features the respective composer's biography, compositional style, and list of works, along with an overview of the two selected works for each, with recommended pedagogical approaches.

On a personal note, the author had opportunity to perform the third movement of Milhaud's Scaramouche during her undergraduate studies, providing her first experience with playing Latin folk tunes. Although she was not aware at that time that this piece was written by a French composer using Latin folk elements, she developed a keen interest in this composer and his style. This experience sparked her curiosity about other compositions by Milhaud and by other non-Latin composers who use Latin folk elements. She was also drawn to Gottschalk, as a composer who uses Afro-Cuban folk melodies, swing syncopation, and ragtime style to create an exotic sound.

In the middle of the $19^{\text {th }}$ century, Romantic music in particular dominated concert music in Europe. Many composers at the time incorporated Romantic characteristics such as chromaticism, nationalism, song-like melodies, dramatic contrast, and programmatic elements.

Milhaud and Gottschalk were among those who also sought inspiration elsewhere and brought the exotic beauty and expressive qualities of Latin folk tunes into their compositions. Many piano pieces by these two composers not only include folk elements from Latin America but also reflect many other European music traditions such as bitonality/polytonality, lyrical melodies, and technical virtuosity.

In this project, the author considers it a privilege to examine more closely some of the specific folk tunes which had already interested her. It is her hope that this research proves to be 
a practical and useful resource for musicians, performers, teachers, and students wishing to learn more about some of the music influenced by Latin cultures. Furthermore, this study hopes to assist pianists in developing an informed interpretation of each piece, based on an understanding of the composer's fusion of musical styles, along with consideration of some of the pedagogical issues for learning or teaching these pieces. 


\section{Chapter 2}

\section{Related Literature}

Notable resources used for obtaining current information about what has already been written concerning the pieces that this research project discusses include: Project MUSE, WVU libraries, University of Calgary libraries, and E-Z Borrow. Relevant keywords in these online searches included "Louis Moreau Gottschalk," "Darius Milhaud," "Caribbean folk music," "ragtime music," "Brazil tango," "Brazil samba," and "two piano works in $20^{\text {th }}$ century," with the most relevant databases including Grove Music Online, WorldCat, JSTOR, and ProQuest.

One particularly useful resource is a thesis titled "Louis Moreau Gottschalk, John Sullivan Dwight, and the Development of Musical Culture in the United States, 1853-1865," by Laura Moore Pruett. ${ }^{1}$ Pruett divides her study into seven chapters: 1) Background: A year of beginnings, 2) The cult of virtuosity in America, 3) From the playhouse to the Parlor: The Banjo and Bunker hill, 4) Exoticism in the United States and beyond, 5) North versus South: L'union and "Dixie's land," 6) Last hopes and singing martyrs: the commodification of music, sentimentalism, and religion, and 7) Conclusion. Throughout her study, Pruett describes Gottschalk's musical style, provides musical examples, and outlines analyses and pedagogical ideas that are useful to performers.

\footnotetext{
${ }^{1}$ Laura Pruett, "Louis Moreau Gottschalk, John Sullivan Dwight, and the Development of Musical Culture in the United States, 1853-1865," (D.M.A. diss., The Florida State University College of Music, 2007).
} 
Another applicable resource for this study is Jihyun Park's dissertation "Louis Moreau Gottschalk’s Assimilation of African American Elements in Souvenir de Porto Rico,"2 completed in 2009. This study examines Gottschalk's piano solo Souvenir de Porto Rico. The chapter entitled "Analysis of Souvenir de Porto Rico" is organized into three sections: Main Elements, Early Jazz Elements, and Recital Reflection. In this study, Park describes the elements that Gottschalk drew from Creole culture and how he adapted those traits into Souvenir de Porto Rico.

"An American in Paris: Musical Exoticism in the Solo Piano Works of Louis Moreau Gottschalk,"3 a dissertation by Jonathan Edward Verbeten, focuses on Gottschalk's piano solo works in three chapters. In Chapter One, he discusses Gottschalk's Bamboula. In Chapter Two, he describes three prominent piano virtuosos performing in Paris during the 1840s and explains the ways in which Gottschalk modeled much of his career on the music of Frederic Chopin. In Chapter Three, Verbeten examines the pieces Gottschalk composed after his return to the United States in 1853. He mentions Souvenir de Porto Rico in Chapter Two to give an example of how different Gottschalk's compositional style was from Chopin's. This dissertation is helpful for understanding Gottschalk’s compositional style as demonstrated in his piano works.

An important element that appears in Gottschalk's Souvenir de Porto Rico is his use of Afro-Caribbean rhythms. The book From Afro-Cuban Rhythms to Latin Jazz by Raul A.

\footnotetext{
2 Jihyun Park, "Louis Moreau Gottschalk's Assimilation of African American Elements in Souvenir De Porto Rico," (M.M. thesis, University of California, 2009).

${ }^{3}$ Jonathan Edward Verbeten, "An American in Paris: Musical Exoticism in the Solo Piano Works of Louis Moreau Gottschalk," (M.M. thesis, University of Arkansas, 2012).

${ }^{4}$ Raul A Fernandez, From Afro-Cuban Rhythms to Latin Jazz, (California: University of California Press, 2006).
} 
Fernandez provides an overview of typical rhythmic figures and provides examples showing these rhythms.

Another relevant reference that examines Gottschalk's piano music is “Building Blocks of a National Style: An Examination of Topics and Gestures in Nineteenth-Century American Music as Exemplified in Scott Joplin's Treemonisha," ${ }^{5}$ by researcher Elisabet Omarene de Vallee at the University of Northern Colorado. In this dissertation, the author explores Scott Joplin's 1911 opera “Treemonisha," which blends African-American topics, Afro-Cuban rhythms, and European art-music traditions. In this research, de Vallee sometimes uses Gottschalk's piano works as examples.

The chapter "From Contradanza to Danzón" in the book Creolizing Contradance in the Caribbean ${ }^{6}$ by Peter Manuel provides a general overview of Cuban music. The author categorizes this chapter into several sections and provides a general background for Gottschalk, along with his piano works including Souvenir de la Havane. He particularly focuses on analyzing Souvenir de la Havane in this chapter.

Shao-Shan Chen's dissertation “The Transformation of Caribbean Dances in Selected Piano Works of Louis Moreau Gottschalk" includes information about his piano works that incorporate Cuban rhythms, most notably in Chapter Three, “Gottschalk’s Piano Works Composed in Cuba." Chapter Four in Chen's dissertation discusses elements of Puerto Rican dance music in Gottschalk's compositions. Both chapters are relevant to this study, as they

\footnotetext{
${ }^{5}$ Elisabet Omarene de Vallée, "Building Blocks of a National Style: An Examination of Topics and Gestures in Nineteenth-Century American Music as Exemplified in Scott Joplin's "Treemonisha," (D.M.A. diss., University of Northern Colorado, 2017).

${ }^{6}$ Peter Manuel, ed., Creolizing Contradance in the Caribbean, (Philadelphia: Temple University Press, 2011).

${ }^{7}$ Shao-Shan Chen, "The Transformation of Caribbean Dances in Selected Piano Works of Louis Moreau Gottschalk," (D.M.A. diss., University of Cincinnati, 2003).
} 
provide in-depth information about folk-rhythm usage and its formal implications, which are seen throughout this paper. In Chapter Five, Chen provides an overview of Gottschalk's musical influences on the coming generation.

"Louis Moreau Gottschalk's Pan-American Symphonic Ideal"8 by Douglas Shadle examines both his small Latin American dance pieces and his two symphonies for full orchestra, both of which contain Latin American themes and imagery. This article studies Gottschalk's musical and compositional philosophies.

Ilan Stavans edited the book Latin Music: Musicians, Genres, and Themes, ${ }^{9}$ which provides general information by keywords. This book offers material on Afro-American music, Puerto Rico traditional music, Latin folk elements, and Brazilian folk tunes.

"A Study on Louis Moreau Gottschalk’s Early Piano Music"10 by Miseon Park was submitted to Kookmin University in 2017. This thesis consists of four chapters which address respectively the composer's historical background, his musical characteristics, an analysis of Le Bananier, and an analysis of The Banjo, op. 15. While this paper explores considerations outside the scope of my research, the content is related, as there are some useful materials which explain how and why Gottschalk adopts Latin elements for his piano works.

Another Gottschalk resource that provides useful information is "Louis Moreau Gottschalk (1829-1869): The role of early exposure to African-derived musics in shaping an

\footnotetext{
${ }^{8}$ Douglas Shadle, “Louis Moreau Gottschalk's Pan-American Symphonic Ideal," American Music 29, no. 4 (2011): 443-71. doi:10.5406/americanmusic.29.4.0443.

${ }^{9}$ Ilan Stavans, ed., Latin Music: Musicians, Genres, and Themes, (ABC CLEO, 2014).

${ }^{10}$ Miseon Park, “A Study on Louis Moreau Gottschalk’s Early Piano Music,” (D.M.A. diss., Kookmin University, 2017).
} 
American musical pioneer from New Orleans"11 by Amy Elizabeth Unruh. This dissertation was submitted to Kent State University in 2009 and is organized into eleven chapters which are very comprehensive in scope. Gottschalk's Souvenir de la Havane is presented in Chapter Five:

Musics in the Caribbean and Latin America. This paper explores Gottschalk's work, along with the African roots of Caribbean and New Orleans music.

"A Study on the Discriminative Elements in Scaramouche of Darius Milhaud" Kwang Bok Lee was submitted to Kyungpook National University in 2015. Lee provides the background of Scaramouche and analysis of the piece along with musical features. She presents all three movements and her discussion of the third movement has been useful to my research.

Monty Roy Musgrave provides significant knowledge of Darius Milhaud in his dissertation "A wind ensemble adaption and conductor's analysis of selected movements of Darius Milhaud's Saudades do Brazil, with particular examination of the influences of Ernesto Nazareth." ${ }^{\prime 13}$ This paper consists of five chapters, and Milhaud's Saudades do Brasil is discussed in Chapter Two. The beginning chapter, which presents Milhaud's historical background, examines the conditions of Milhaud's life when this piece was written. Interestingly, Musgrave analyzes the piano arrangement first and then provides an overview of the arrangement for wind ensemble. Examining both renditions of this work provides further insight regarding Milhaud's artistic vision for the piece.

\footnotetext{
${ }^{11}$ Amy Elizabeth Unruh, "Louis Moreau Gottschalk (1829-1869): The Role of Early Exposure to African-Derived Musics in Shaping an American Musical Pioneer From New Orleans," (Ph.D. diss., Kent University, 2009).

${ }^{12}$ Kwang Bok Lee, "A Study on the Discriminative Elements in Scaramouche of Darius Milhaud," (D.M.A. diss., Kyoungpook National University, 2015).

${ }^{13}$ Monty Musgrave, "A Wind Ensemble Adaptation and Conductor's Analysis of Selected Movements of Darius Milhaud's "Saudades Do Brazil", with an Examination of the Influences of Ernesto Nazareth," (D.M.A. diss., Louisiana State University, 2005).
} 
Li Liang examines Brazilian musical elements in the third movement, Brasileira, of Milhaud's Scaramouche in her master's thesis “An Analysis of Various Characteristics in Darius Milhaud's Music and Scaramouche," ${ }^{14}$ submitted in 2014. She organizes the research into four main categories: 1) overview of Milhaud's background, 2) the composer's musical characteristics, 3) Milhaud's output, and 4) Scaramouche.

In "Darius Milhaud in the United States, 1940-71: Transatlantic constructions of musical identity," ${ }^{\prime 5}$ Erin K. Maher explores Milhaud's activity in the United States. Maher believes that Milhaud's musical activities were affected by his French and Jewish identities. Though the main area of study in this research is different from that of my paper, this work is still relevant to my research in that Maher examines Milhaud's two-piano piece Scaramouche numerous times throughout the chapters.

The article "Discussion About Darius Milhaud and His Work: Double Piano Cento [sic] Scaramouch" ${ }^{\prime 16}$ was published in Cross-Cultural Communication Canada in 2015. This article is divided into two parts: 1) brief description of Milhaud and his life experience, and 2) "Scaramouche," an analysis of its musical form and structure. The first part consists of six sections by periods; the second part is divided into three sections by movements.

"Milhaud and the French Musical Tradition with reference to his work 1912-31,"17 a dissertation by Barbara Lucy Kelly, is divided into six chapters: 1) The French Tradition, 2)

\footnotetext{
${ }^{14}$ Li Liang, "An Analysis of Various Characteristics in Darius Milhaud's Music and Scaramouche," (M.A. thesis, Hanyang University, 2014).

${ }^{15}$ Maher Erin, "Darius Milhaud in the United States, 1940-71: Transatlantic Constructions of Musical Identity," (Ph.D. diss., University of North Carolina, 2016).

${ }^{16}$ Dengbin Gao, "Discussion About Darius Milhaud and His Work: Double Piano Cento Scaramouch," CrossCultural Communication, 11, no. 11 (2015): 63-67.

${ }^{17}$ Barbara L Kelly, "Milhaud and the French Musical Tradition with reference to his work 1912-31," (Ph. D. thesis, University of Liverpool, 1994).
} 
Milhaud and the French Musical Tradition, 3) Milhaud's Vocal Works. I: The Early Works, 4) Milhaud's Vocal Works. II: New Approaches to Text, 5) Milhaud and Bitonality/polytonality, and 6) Conclusions: Milhaud's Contribution to the French Tradition. Both the third movement of Scaramouche and Saudades do Brasil incorporate both Latin folk elements and European musical traditions. Due to the focus of this study, this dissertation is highly relevant to my research.

Music of the Twentieth Century ${ }^{18}$ is written by Ton De Leeuw. This book introduces the features of $20^{\text {th }}$ century music and examines many factors such as rhythm, melody, timbre, and twelve-tone music throughout the chapters. Exoticism and folkloric elements, which my research will also study, appear in Chapter Six.

Gayle Murchison writes about Les Six in Chapter Four, "Paris and Jazz: French Neoclassicism and the New Modern American Music," in her book American Stravinsky. ${ }^{19}$ In a section about Milhaud's influence, Murchison mentions the nationalism of Les Six and Copland's “Jazz as Modern Music.”

"Tradition and Style in the Works of Darius Milhaud 1912-1939"20 is written by Barbara L. Kelly and consists of seven chapters. Milhaud's piano solo piece Saudades do Brasil is presented in Chapter Six to support Kelly's explanation of polytonality. Polytonal writing is mentioned in my research.

Jason A. Stone studies the Brazilian elements in Milhaud's style in his master's thesis, "Brazilian influences on Milhaud's Scaramouche, op. 165."21 He divides his work into four

\footnotetext{
${ }^{18}$ Ton de Leeuw, Music of the Twentieth Century, (Amsterdam: Amsterdam University Press, 2005).

${ }^{19}$ Gayle Murchison, American Stravinsky, (Ann Arbor: University of Michigan Press, 2012).

${ }^{20}$ Barbara L Kelly, Tradition and Style in the Works of Darius Milhaud 1912-1939, (New York: Routledge, 2016).

${ }^{21}$ Jason A. Stone, "Brazilian Influences on Milhaud's "Scaramouche," op. 165," (M.M. thesis, California State University, 1999).
} 
chapters, focusing on Scaramouche in Chapter Three, which also describes Brazilian influences in Saudades do Brasil.

"The Piano Music of Darius Milhaud, a Survey"22 by Mary Jane Rupert, was submitted to Indiana University in 1974; this dissertation also discusses Milhaud's two-piano pieces. Rupert divides her research into eleven chapters, arranging them by musical style and by the difficulty level of the pieces. Saudades do Brasil belongs to the chapter about programmatic piano pieces, which is a style element that is also discussed in my research.

The dissertation "The Solo Piano Music of Darius Milhaud with Suggestions for its Instructional Use"23 by Patricia Taylor Lee illustrates the characteristics of Milhaud's solo piano works. Saudades do Brazil is briefly introduced in Chapter Three, along with mentioning other versions of this material for orchestra, for piano and violin, and for piano and cello.

These sources, along with additional books, dissertations, articles, and personal blogs, provide a strong foundation for the research in this study. It is clear that researchers are taking different pathways to examine some of the same materials.

This research will build upon this information, being the first to discuss specifically the differences between how native Latin composers and Gottschalk and Milhaud use folk music elements. Arguably, these two composers' output is quite different from that of native Latin composers, even when they rely on the same folk-music materials.

The most relevant resources that inform this research are the theses and dissertations that study Gottschalk and Milhaud, the influences on their music, and their compositional style, along

\footnotetext{
${ }^{22}$ Mary Jane Rupert, “The piano music of Darius Milhaud: A survey,” (D.M.A. diss., Indiana University, 1974).

${ }^{23}$ Patricia Lee, "The solo piano music of Darius Milhaud with suggestions for its instructional use," (D.M.A. diss., Temple University, 1979).
} 
with a number of published books and articles that directly discuss Souvenir de Porto Rico;

Souvenir de la Havane; Saudades do Brasil; and Brasileira, the 3rd movement of Scaramouche. 


\section{Chapter 3}

\section{Louis Moreau Gottschalk}

\section{Biography}

Louis Moreau Gottschalk was one of the most celebrated American concert pianists and composers in the middle of the $19^{\text {th }}$ century. He was born in New Orleans in 1829 and grew up in a neighborhood where Creole music with African-Caribbean rhythms and folk melodies was popular. New Orleans developed as a major city of racial and ethnic diversity, including such groups as colonial French, Spanish immigrants, and Haitian refugees.

By the 1830s, the Louisiana territory had become a melting pot of diverse races and classes, and the city was comprised of three main groups of people: whites, blacks, and Creoles. In 1828, Edward Gottschalk, Gottschalk's father, who was a wealthy English Jew, married a fifteen-year-old Creole of Saint Domingue descent, Aimée Bruslés Gottschalk. Louis Moreau was their first child and was recognized as a musical prodigy at the age of four. During his early years, he experienced many different musical cultures which are later reflected in his own music.

In the 1830s, African musical cultures and European musical styles were the most popular in New Orleans and Gottschalk was inspired by these international cultural streams. New Orleans had one of America's first grand opera houses, which regularly offered grand and comic operas by Bellini, Donizetti, Rossini, Meyerbeer, and others. Gottschalk was especially inspired by Meyerbeer's method of harmonization. ${ }^{24} \mathrm{He}$ was also influenced by his local environment. For instance, his nurse Sally sang the mournful spiritual songs of the Louisiana slaves to him, and he often observed street vendors dancing, singing, and drumming.

\footnotetext{
${ }^{24}$ S. Frederick Starr, Louis Moreau Gottschalk, (Urbana and Chicago: University of Illinois Press, 2000 ), 38.
} 
Gottschalk's musical gift was recognized by his father when at the age of four Louis could play on the piano the melodies that he had heard. He began to have piano lessons from Francois Letellier, who was one of the musicians of the Orleans Theatre. Young Gottschalk also had opportunities to perform at church as early as age seven. He became a rising star in the city at an early age, and his father and teacher decided to send him to Paris because Classical training in Europe would be required to achieve Louis Moreau's musical goals. Unfortunately, the Paris Conservatory rejected his application because Gottschalk was from America, so he began studying piano privately with Carl Halle in Paris in 1842. Six months later, he began studying composition with Camille-Marie Stamaty and Pierre Malenden. Fortunately, Gottschalk was able to advance his musical career because of various opportunities to perform at private salons, opera houses, and concert halls which were patronized by wealthy Parisians. He earned fame as a performer and he made his debut as a professional pianist in Paris with Chopin's Concerto in e minor, Thalberg's Fantasy from Rossini's Semiramide, and Liszt's Fantasy from Meyerbeer's Robert le Diable. His idol, Chopin, who attended this concert, praised him and predicted that Gottschalk would be one of the foremost pianists of the century.

This fifteen-year-old musician not only succeeded as a pianist but also began to earn fame with his Creole compositions: Bamboula, op. 2, which was from his remembrances of the Congo Square dances in New Orleans; La Savane, op. 3, which was reminiscent of Sally's songs; Le Bananier, op. 5 (Chanson des nègres); and Le Mancenillier, op. $11 .^{25}$

In 1851 Berlioz noted:

Mr. Gottschalk was born in America, whence he has brought a host of curious chants from the Creoles and Negroes; he has made from them the themes of his

\footnotetext{
${ }^{25}$ Park, Louis Moreau Gottschalk's Assimilation, 18.
} 
most delicious compositions. Everybody in Europe now knows Bamboula, Le Bananier, Le Mancenillier, La Savane, and twenty other ingenious fantasies. ${ }^{26}$

Gottschalk's compositions were influenced not only by his Creole background but also by the Romantic style of composers such as Chopin, Liszt, and Berlioz. This mixture of two influences undoubtedly helped him become one of the most popular musicians in Paris. However, after concert tours with his compositions during 1850-1852 in Switzerland, France and Spain, he returned to the United States in 1853 , because he was no longer receiving invitations from patrons. In the same year, Gottschalk received enthusiastic notice from many critics after his first concert in Boston and his flamboyant style brought him favor from audiences.

On the other hand, according to Starr, his performance of Bamboula, La Savane, and Le Bananier also received negative criticism such as "neither brilliant, imaginative, or even difficult, and too eccentric, and too American." ${ }^{27}$ As Gottschalk continued composing, his pieces became more sentimental and Romantic; examples such as The Dying Poet and The Last Hope reflect his identity as a Romantic composer.

After 1854, he gave several concerts in the West Indies and he finally decided to settle in Cuba in 1856. In his new country, he directly experienced Cubans' love for music and dance. It was also unavoidable that Cuban dance music left its mark on many of his compositions, as it must also have influenced his performance style. ${ }^{28}$ Souvenir de Porto Rico, op. 31 (1857) and Souvenir de la Havane, op. 39 (1859) were composed during this time.

\footnotetext{
${ }^{26}$ Ned Sublette, Cuba and lts Music: From the First Drums to the Mambo, (Chicago: Chicago Review Press, 2007), 149 .

${ }^{27}$ Starr, Louis Moreau Gottschalk, 136.

${ }^{28}$ Ibid, 183.
} 
Gottschalk continued his musical career as pianist and composer in Cuba until 1862, when he returned to the United States to renew his career in this country. Having been away for six years, he started with an informal concert at the house of his friend Louis Descombes. At this recital, many experts including writers, critics, and musicians were invited. Their complimentary consensus was that during his years in the West Indies Gottschalk had deepened as a composer and pianist. A series of concerts followed in rapid succession and he returned to New York a hero. During the Civil War, Gottschalk toured from 1862 to 1865 for concerts in many cities in the Northern United States and Canada, and he became one of the most widely acclaimed artists. Gottschalk made his concert tours in the western states in 1865 , but he had to leave the area after these tours because of the unpleasant news of a scandal with a young student. Instead of returning to New York he decided to go to South America, which was his dream, and he stayed in Peru for one year. After working in various South American cities until 1869, Gottschalk arrived at Rio de Janeiro in Brazil, which was a flourishing area with cosmopolitan musical audiences of German, Italian, French, and Spanish backgrounds. ${ }^{29}$

With the emperor's personal support in this city, Gottschalk managed to secure several concerts and contracts with the aristocrat Ricardo Ferreira de Carvalho. He was able to have his own orchestra and assistant pianists for himself for the grand concert and his first few series were successful. His gala concerts with orchestra were scheduled on November 25 and 26, but his poor health pulled him down on the second day of the concert. Gottschalk collapsed after playing Morte!!, which was his newest composition; unfortunately, he steadily got worse and died in

\footnotetext{
${ }^{29}$ John Godfrey Doyle, "The Piano Music of Louis Moreau Gottschalk (1829-1869)," (Ph. D. thesis, New York University, 1960), 11-44.
} 
December, 1869. His desire to return to the United States and open an entirely new phase of his career was thus left unfulfilled. ${ }^{30}$

${ }^{30}$ Starr, Louis Moreau Gottschalk, 422. 


\section{Compositional Style of Gottschalk's Piano Works}

Louis Moreau Gottschalk was the first virtuoso pianist-composer in America during the mid-1 $19^{\text {th }}$ century. Not only did he achieve success as a concert pianist in North America, Europe, and South America, but he also composed remarkable pieces that brought him fame. His compositional style for piano reflects many influences that he had experienced from childhood in America, overseas in Paris, and during visits to other countries.

As mentioned in his biography above, his childhood in New Orleans was rich with African music and dance. His piano compositions vary in genre, form, and artistic style because of these cultural influences, along with his environment (in which his parents, teachers and musical idols surrounded him) and the general circumstances of the era during which he lived. Nevertheless, it is not simple to divide his piano compositions into specific categories by any criteria.

Gottschalk's piano music is not necessarily an accurate representation of American musical idioms. Instead, it should be understood as an attempt by Gottschalk to market himself to the audiences because of their craze for exotic cultures during his time. ${ }^{31}$ Moreover, he had the chance to hear Caribbean folk songs from family members who were Creoles of French descent from Saint-Domingue, which is now known as Haiti. This folk music particularly affected many of his compositions during his teenage years in Paris. These works' characteristics were similar to those of Chopin's Mazurkas and Liszt's Hungarian Rhapsodies, which also include native exotic Polish and Hungarian dances. ${ }^{32}$ The representative pieces from his New

\footnotetext{
${ }^{31}$ Verbeten, An American in Paris, abstract.

${ }^{32}$ Ibid, 7.
} 
Orleans Afro-Creole heritage are Bamboula (1844), La Savane (1846), El Cocoyé (1854), Le Mancenillier (1849), and Le Banjo (1854).

Gottschalk also used Spanish dance materials for some of his piano compositions. One representative piece is La Jota Aragonesa (1852) which borrows the theme from Mikhail Ivanovich Glinka's Jota Aragonesa (1845). Additionally, his compositions Souvenirs d'Andalousie (1851), and Minuit à Seville (1856) are distinguished piano works that represent many Spanish elements, including guitar figurations and imitation of castanets, along with seguidilla, fandango, and flamenco rhythms. ${ }^{33}$

While Gottschalk was studying in Paris during the 1840s, he was significantly influenced by three composers: Frédéric Chopin, Franz Liszt, and Sigismond Thalberg. Gottschalk had particularly great admiration for Chopin as a composer; thus, his output of piano composition is closely related to Chopin's. His character piece Morte!!, written in 1868, depicts a funeral scene and resembles Chopin's funeral march in the latter's Piano Sonata no. 2. Morte!! was performed throughout many countries, to great demand. According to Park, when Gottschalk performed Morte!! (the title of which means "(s)he is dead"), a great many women reacted with ostensibly emotional responses. ${ }^{34}$

Many of Gottschalk's piano compositions are character pieces which are neither long nor serious. They are often based on simple melodies and rhythms that suggest folk idioms, without necessarily focusing on specific folk-music thematic materials. These entertaining character pieces were loved by audiences, including at salon concerts. Another example of these short

\footnotetext{
${ }^{33}$ Chen, The Transformation of Caribbean Dances, 21.

${ }^{34}$ Park, Louis Moreau Gottschalk's Assimilation, 22, quoted in S. Frederick Starr, Bamboula! The Life and Times of Louis Moreau Gottschalk, (New York: Oxford University Press, 1995).
} 
Romantic works is his piano piece Ricordati, composed in 1856 . This salon piece also shows the influence of Chopin's nocturnes as it has the subtitle 'Nocturne for piano.' Gottschalk produced piano character pieces in diverse forms, including variation, mazurka, etude, ballade, scherzo, etc. Representative among his piano character pieces are The Last Hope, Le Carnaval de Venise, Berceuse, and The Dying Poet.

Since Gottschalk was renowned as an American pianist and composer, he also followed the popular trend set by American composers of parlor songs, such as Stephen Foster, and by the popular minstrel groups. ${ }^{35}$ Moreover, he often quoted well-known American tunes in his piano works. Although he had received his musical training from an early age in Europe, his fans in New York expected him to show his patriotism as an American. L'Union, paraphrase de concert for piano (1862) was the result of that demand and was often performed in America during the Civil War. This work uses three famous American tunes: Yankee Doodle, The Star-Spangled Banner, and Hail, Columbia. ${ }^{36}$ Similarly, the theme of Stephen Foster's minstrel song Camptown Races appears in Gottschalk's The Banjo. His beloved The Last Hope also quoted materials from the hymn Ghost with Light Divine.

Gottschalk's music composed in the West Indies during his visits in 1854 and his residence in 1856-1862 shows the strong influence of Cuban traditional folk materials. Even though his early compositions in Paris also exhibit typical Afro-Cuban musical characteristics, his compositions while living in the West Indies are certainly worthy of study. Remarkably, he did not only adopt the rural music but also established his own music style with it. His Souvenir

\footnotetext{
${ }^{35}$ Verbeten, An American in Paris, 6.

${ }^{36}$ David Dubal, “A Rousing Anthem of National Unity,” The Wall Street Journal, June 28, 2013, https://www.wsj.com/articles/SB10001424127887324577904578559401212056738/ (accessed July 15, 2019).
} 
de Porto Rico and Souvenir de la Havane, which were composed during this period, will be discussed in the next chapter, following a complete listing of his piano works. 


\section{List of Gottschalk Piano Works}

Year Title

1871 The Dying Poet, meditation for piano, 4 hands (arranged by Charles Wells)

1870 The Last Hope, meditation for piano, 4 hands

1870 Ses Yeux, polka de concert for piano, op. 66, D. 137a

1870 Printemps d'amour, mazurka: caprice de concert for piano, 4 hands, D. 125

1870 Orfa, grande polka for piano, 4 hands, op. 71, D. 108a

1870 Mazurk, for piano in F sharp minor, D. 93

1870 Ballade, for piano No. 8, op. 90, D. 12

1870 Ballade, for piano No. 7, op. 87, D. 11

1870 Ballade, for piano No. 6, op. 83 and 85, D. 12

1869 Variations de concert sur l'hymne portugais, for piano, op. 91, D. 157

1869 Tremolo, grande étude de concert for piano, op 58, D. 154

1869 The Dying Swan, romance poétique for piano, op. 100, D. 46

1869 Pasquinade, caprice for piano, op. 59, D. 113

1869 Pasquinade, caprice for piano, 4 hands, op. 59

1869 Madeleine, etude for piano, D. 83

1869 Impromptu, for piano, op. 54, D. 74

1869 Hercule, grande étude de concert for piano, op. 88, D. 68

1869 Grande Fantaisie triomphale sur l'hymne national brésilien, op. 69, D. 63

1869 Grand Scherzo, for piano, op. 57, D. 65

1869 Forget me Not, mazurka caprice for piano, D. 59

1869 Denier amour, étude de concert, op.62 and 63, D. 43

1868 Vision, étude for piano, D. 158

1868 Morte!! (She is Dead), lamentation for piano, op. 60, D. 100

1868 Grande Tarantelle, for piano, op. 67

1868 Grande Tarantelle, for piano, 4 hands, op. 67

1868 Grande Tarantelle, for 2 pianos, op. 67

1868 Caprice élégiaque, for piano, op. 56, D. 25

1867 Bataille, étude de concert for piano, op. 63 and 64, D. 17

1866 Marguerite, grande valse brillante for piano, op. 76, D. 92

1865 Souvenir de Lima, mazurka for piano, op. 74, D. 146

1865 Ses Yeux, polka de concert for 2 pianos, op. 66, D. 137

1865 La Brise, valse de concert for piano (The Breeze), D. 23

1864 La Gallina, danse cubaine for piano, op. 53, D. 60

1863 The Maiden's Blush, grande valse de concert for piano, D. 84

1863 The Dying Poet, meditation for piano, D. 45

1863 Orfa, grande polka for piano, op. 71, D. 108

1863 La Colombe, petite polka, op. 49, D. 37

1863 Battle Cry of Freedom, grand caprice de concert for piano, op. 55, D. 18

1862 Pensive, polka-rédowa for piano, D. 199

1862 L'Union, paraphrase de concert for piano, op. 48, D. 156

1862 Home Sweet Home, caprice for piano, op. 51, D. 69 
1861 Suis-Moi!, contradanza for piano, op. 45, D. 157

1861 O ma charmante, épargnez-moi!, caprice for piano, op. 44, D. 107

1861 Berceuse, cradle song for piano, op. 47, D. 20

1860 Symphony No. 1: La nuit des tropiques (Night in the Tropics), for 2 pianos

1860 Murmures éoliens, for piano, p. 46, D. 102

1860 La Chute des feuilles, nocturne for piano, op. 42, D. 34

1859 Souvenir de la Havane, caprice de concert for piano, op. 39, D. 145

1859 Souvenir de Cuba, mazurka for piano, op. 75, D. 144

1859 Réponds-moi, danse cubaine: caprice brillante for piano, 4 hands, op. 50, D. 131

1859 Romance, for piano in E flat major, D. 134

1859 Radieuse, grande valse de concert for piano, op. 72

1859 Radieuse, grande valse de concert for piano, 4 hands, op. 72, D. 127

1859 Polonia, grande caprice de concert, op. 35/43, D. 124

1859 Polka (II), for piano in A flat major, D. 120

1859 Polka (I), for piano in B flat major, D. 121

1859 Pastorella e cavalliere, for piano, op. 32, D. 114

1859 Ojos Criollos - danse cubaine, caprice brillante for piano, op. 37, D. 105a

1859 Ojos Criollos - danse cubaine, caprice brillante for piano, 4 hands, op. 37, D. 105

1859 La Gallina, danse cubaine for piano, 4 hands, op. 53, D. 60

1859 La favorita, grande fantaisie triomphale de concert (after Donizetti), D. 54

1859 Jeunesse, mazurka brillante for piano, op. 70, D. 78

1859 Hurrah Galop, galop de concert, D. 70

1859 Fantôme de Bonheur, caprice for piano, op. 36, D. 51

1859 Fairy Land (Dans les nuages), schottische de concert for piano, D. 50

1859 Columbia, caprice américaine for piano, op. 34, D. 38

1858 Love and Chivalry, caprice élégant en forme de schottische for piano, op. 97, D. 82

1857 Ynés (Inés), danza for piano, D. 161

1857 Souvenir de Porto Rico, marche des gibaros for piano, op. 31, D. 147

1857 La Gitanella, caprice caractéristique for piano, op. 35, D. 61

1857 Danza, contradance for piano, op. 33, D.

1857 Chant de Guerre, polka for piano, op. 78, D. 30

1856 Sospiro, valse poétique for piano, op. 24, D. 142

1856 Reflets du passé, rêverie for piano, op. 28, D. 129

1856 Miserere du Trovatore, concert paraphrase for piano (after Verdi), op 52, D. 97

1856 Apothéose, grande marche solenelle for piano, op. 29, D. 5

1855 Solitude, for piano, op. 65, D. 139

1855 Ricordati, nocturne for piano, op. 26, D. 133

1855 Rayons d'azur, polka de salon for piano, op. 77, D. 128

1855 Printemps d'amour, mazurka: caprice de concert for piano, op. 40, D. 125

1855 Pensée Poétique (II), for piano (L'Extase), op. 61/62, D. 117

1855 Marche de nuit, march for piano, op. 17, D. 89

1855 Marche de nuit, march for piano, 4 hands, op. 17, D. 89a

1855 Le bananier, chanson nègre for piano, 4 hands (arranged by Carl Czerny), op. 5, D. 14a

1854 Tournament Galop, for piano, D. 153

1854 The Last Hope, meditation for piano, op. 16, D. 80

1854 Marche funèbre (II), for piano, op. 64, D. 90b 
1854 Le Chant du martyr, grand caprice religieux for piano, D. 30

1854 Le Banjo, esquisse américaine for piano, op. 15, D. 15

1854 L'Étincelle, mazurka sentimentale for piano, 4 hands (The Spark), op. 21, D. 49a

1854 El cocoyé, grand caprice cubain di bravura for piano, op. 80, D. 35

1854 Chant du Soldat, grande caprice de concert for piano, op. 23, D. 31

1853 Marche funèbre (I), for piano, op. 61, D. 90a

1853 Forest Glade Polka, polka brillante for piano, op. 25, D. 58

1853 Deuxième Banjo, for piano, op. 82, D. 16

1853 Danse des sylphes, caprice de concert (after Godefroid), op. 86, D. 40

1853 Ballade, for piano in A flat major, D. 9

1852 Minuit à Seville, caprice for piano, op. 30, D. 96

1852 Manchega, étude de concert for piano, op. 38, D. 86

1852 La Jota aragonesa, caprice espagñol for piano, op. 14, D. 79

1852 La Jota aragonesa, caprice espagñol for piano, 4 hands, op. 14, D. 79

1852 Chanson du gitano, for piano, D. 28

1851 The Water Sprite, polka de salon for piano, op. 27, D. 159

1851 Souvenirs D'Andalousie, caprice de concert for piano, op. 22, D. 148

1851 Scherzo-romantique, for piano, op. 73, D. 136

1850 Mazurka rustique, mazurka for piano, op. 81, D. 64

1850 Le songe d'une nuit d'été, opera paraphrase for piano (after A. Thomas), op. 9, D. 141

1850 Le Carnaval de Venise, grand caprice with variations, op. 89, D. 27

1850 Jerusalem, grande fantaise triomphale (opera paraphrase, after Verdi) for piano

1850 God Save the Queen (America), morceau de concert for piano, op. 41, D. 62

1849 Le Mancenillier, sérénade for piano, op. 11, D. 45

1849 La chasse du jeune Henri, morceau de concert for piano, op. 10, D. 32

1849 Danse ossianique, for piano, op. 12, D. 39

1848 La Mélancolie, étude caractéristique for piano (after Godefroid), D. 95

1848 La Moissonneuse, mazurka caractéristique for piano, op. 8, D. 98

1848 L'Étincelle, mazurka sentimentale for piano (The Spark0, op. 20, D. 49

1846 Souvenir des Ardennes, mazurka de salon for piano, D. 143

1846 Ossian, ballades (2) for piano, op. 4, D. 109

1846 Le bananier, chanson nègre for piano, op. 5, D. 14

1846 La Savane, ballade créole for piano, op. 3, D. 135

1846 Colliers d'Or, mazurkas (2) for piano, op. 6, D. 36

1844 Polka de salon, for piano, op. 1, D. 123

1844 Bamboula, danse des nègres for piano, op. 2, D. 13 


\section{Souvenir de Porto Rico}

Gottschalk composed Souvenir de Porto Rico, op. 31, in 1856 during his stay in Plazuela, the Caribbean island. In spite of Gottschalk's own description of this five-year period in Plazuela as "lost years," his piano compositions bore fruit with many of the features of vernacular music. Aguinaldo Si Me Dan Pasteles (see Example 3.1), a chant-like melody sung during Christmas season by the Jibaro, a people who farm the lands in the countryside, is source material for this piano composition, and also for a symphony by Manuel Pasarell, a Puerto Rican composer. ${ }^{37}$ According to Gottschalk's diary, he composed this piece while visiting the village of Matouba on the island of Guadeloupe. He had been impressed by a festive musical event in which people went house to house to sing traditional songs such as villancicos and aguinaldos accompanied by traditional instruments. ${ }^{38}$ This composition shows how Gottschalk weaves the traditional Puerto Rican song into his new version for the piano.

\footnotetext{
${ }^{37}$ Starr, Louis Moreau Gottschalk, 266, quoted in John G Doyle, "The Piano Music of Louis Moreau Gottschalk," (Ph. D. diss., New York University, 1960), 146-148.

${ }^{38}$ Maria del Carmen Perez, “Gottschalk and the Caribbean,” (D.M.A. diss., University of Washington, 2001), 75-76.
} 
Example 3.1. Aguinaldo Si Me Dan Pasteles, mm.1-8.
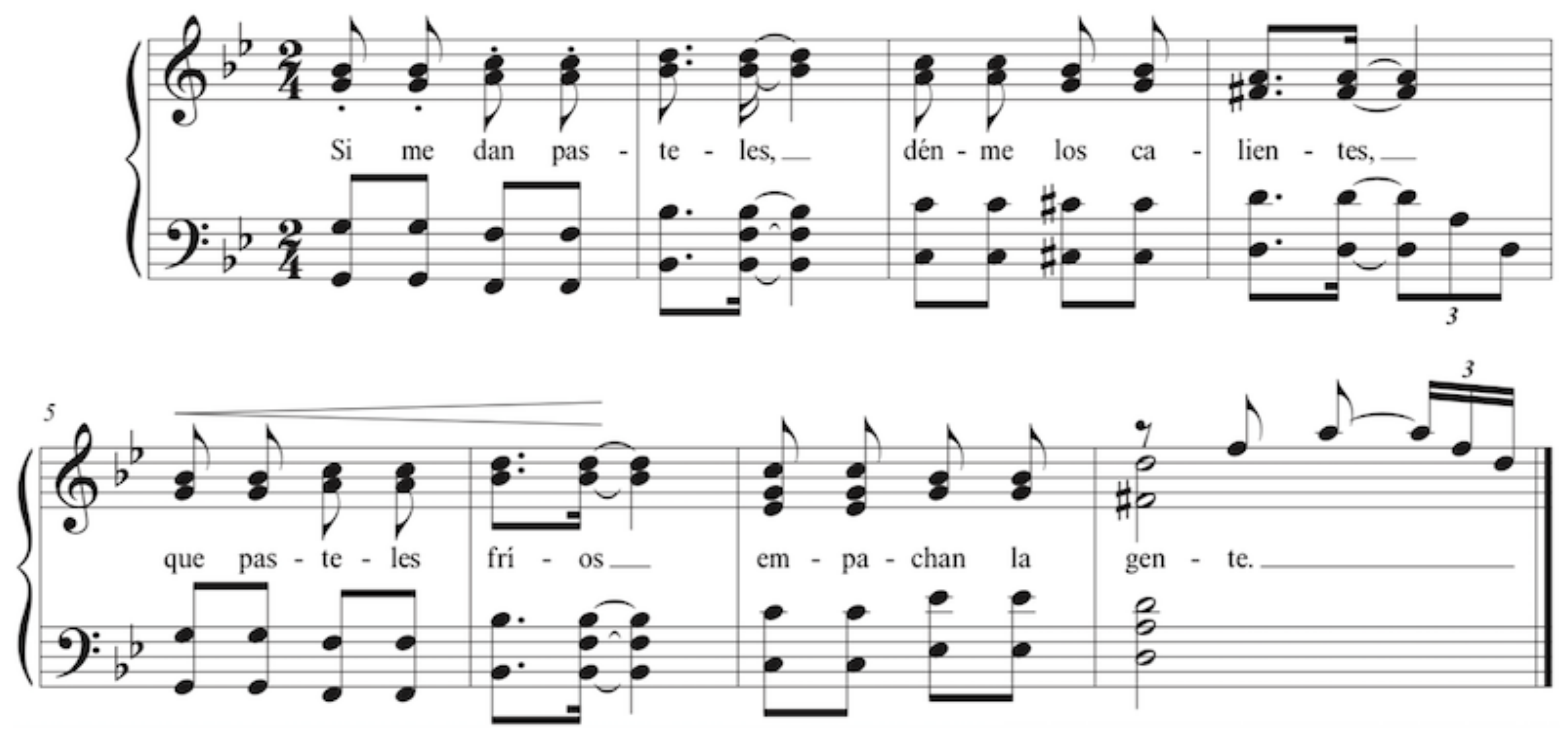

This piece is clearly structured as a theme and variations. Traditional Cuban rhythms are represented repeatedly throughout the entire piece (See Table 3.1). The overall form resembles the Pilgrims' Chorus from Berlioz's Harold in Italy in that it describes the sound of wandering musicians as it comes into earshot, rises to a peak, and then fades away. ${ }^{39}$

The most interesting aspect of this piece is how Gottschalk uses the main theme in each of the variations. Different textures, keys, harmonies, dynamics, rhythms and other features such as chromaticism and hand crossings appear in the variations; the interludes display variety, too, although not as much as among the variations. The next section examines the following musical elements in this work: Formal structure, varied textures, key, harmonic progressions, dynamics, and rhythms, followed by pedagogical aspects.

\footnotetext{
${ }^{39}$ Starr, Louis Moreau Gottschalk, 266.
} 
Table 3.1. Louis Gottschalk, Souvenir de Porto Rico, Formal Structure.

\begin{tabular}{|l|c|c|c|c|c|c|c|c|}
\hline & Opening refrain & Theme & Var. 1 & Interlude & Var. 2 & Interlude & Var. 3 & Interlude \\
\hline Measures & $1-16$ & $17-32$ & $33-48$ & $49-58$ & $59-74$ & $75-84$ & $85-100$ & $101-116$ \\
\hline
\end{tabular}

\begin{tabular}{|c|c|c|c|c|c|c|c|c|}
\hline Var. 4 & Interlude & Var. 5 & Interlude & Var. 6 & Var. 6' & Transition & Var. 3 & Interlude \\
\hline $117-132$ & $133-148$ & $149-164$ & $165-172$ & $173-188$ & $189-201$ & $202-219$ & $220-235$ & $236-251$ \\
\hline
\end{tabular}

\begin{tabular}{|c|c|c|c|}
\hline Var. 7 & Interlude & Closing material & Closing refrain \\
\hline $252-267$ & $268-277$ & $278-285$ & $286-293$ \\
\hline
\end{tabular}

This music begins with a 16-bar opening refrain (see Example 3.2), followed in $\mathrm{m} .17$ by the main theme of the piece (see Example 3.3). After 16 measures of theme, six variations alternate with interludes from mm. 33-201, with the variations revealing changes in rhythms, dynamics, and articulations (see Example 3.4). Next Gottschalk inserts an 18-bar developmental section (see Example 3.5), leading to another variation-and-interlude part which starts at m. 220. Gottschalk uses a virtuosic figure from Var. 5, presented fortissimo, in the middle of the transition; this should be understood as the aesthetic balance point of the piece. This climax eventually fades away through the second part of the transition and leads to another variationand-interlude section. At m. 220, Var. 3 returns and another interlude follows that. After Var. 7 and a shortened form of the interlude, a shortened main theme appears as a closing gesture and the refrain serves to conclude the piece quietly. 
Example 3.2. Louis Gottschalk, Souvenir de Porto Rico, Refrain, mm. 1-8.

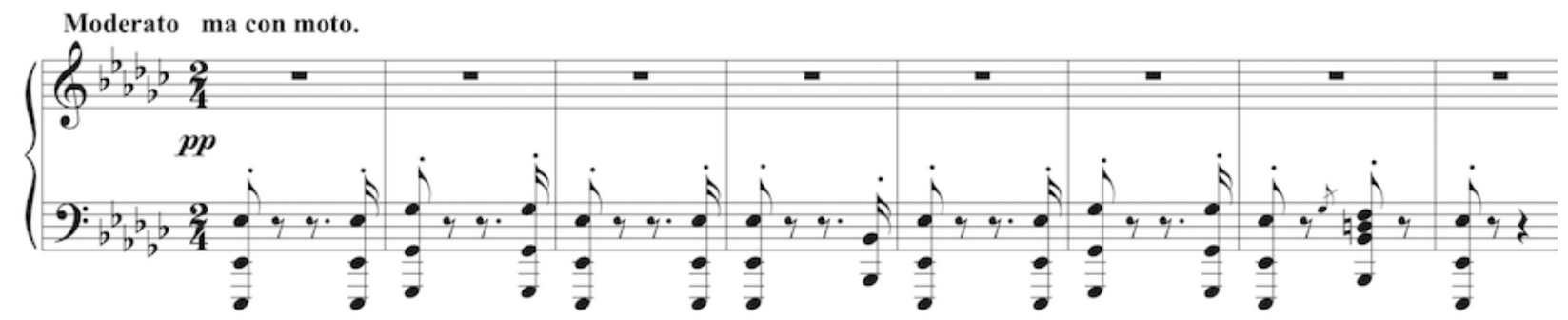

Example 3.3. Louis Gottschalk, Souvenir de Porto Rico, Theme A, mm. 17-23.

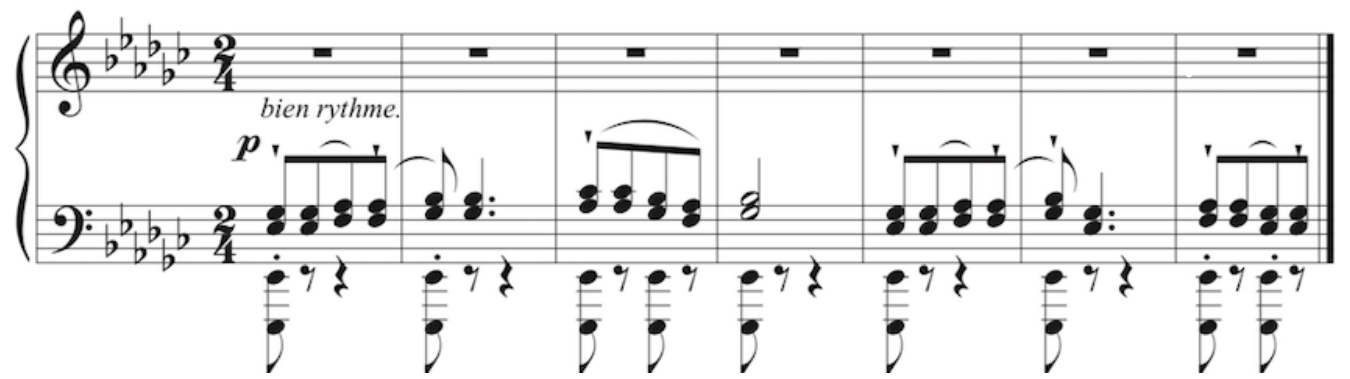

Example 3.4. Louis Gottschalk, Souvenir de Porto Rico, Interlude material, mm. 49-58.
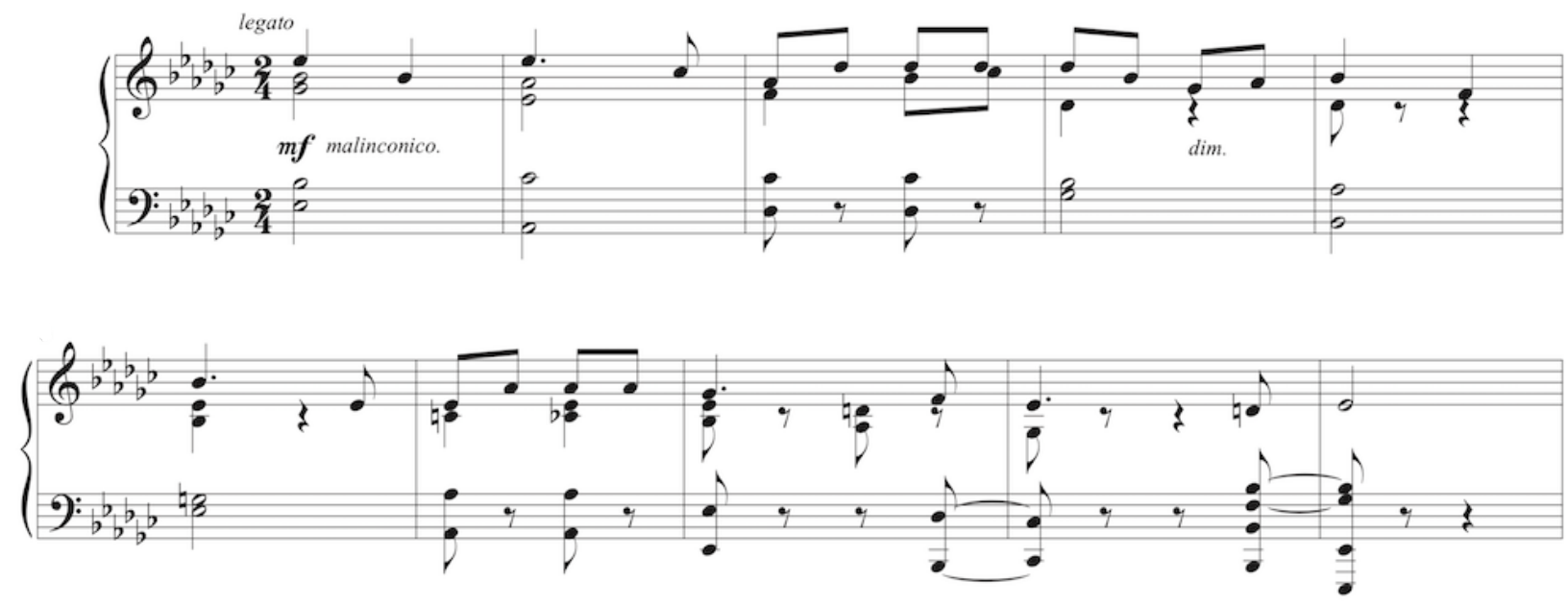
Example 3.5. Louis Gottschalk, Souvenir de Porto Rico, Transition, mm. 202-208.

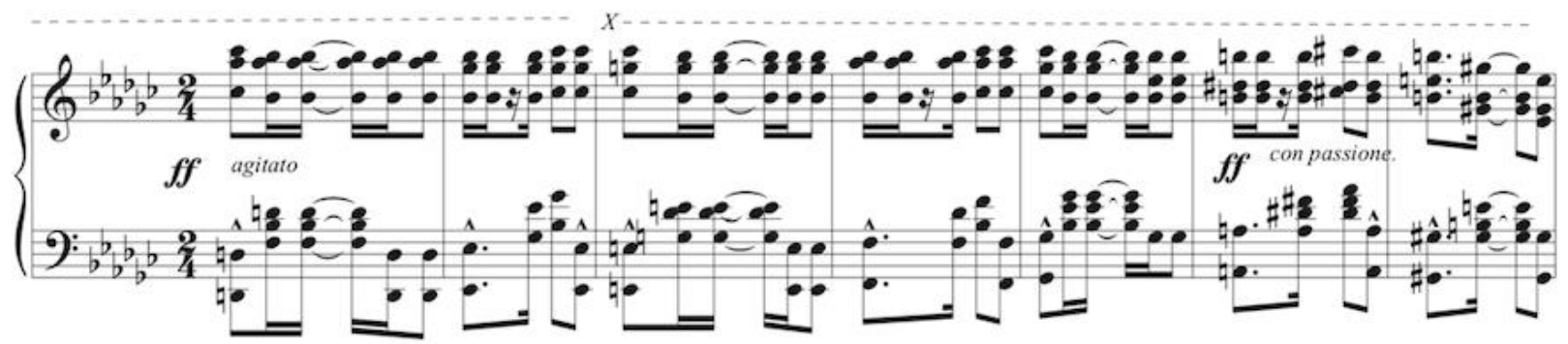

These variations reflect different textures throughout the piece. The variations and interludes before the transition are simple, with thin textures, whereas after the transition they are more complicated and display thicker textures. As already mentioned, the piece starts with two sets of eight-bar refrains in Eb minor. The second eight-bar phrase is a repeat of the first in harmony, rhythm, and articulation, but the top voice joins with the dark and soft lower voices. The mysterious passages in pianissimo octaves arrive with the main theme of the piece in the lower register, and the left-hand bass notes represent the drum. As the refrain repeats with top voice in the treble clef at m. 9, Gottschalk adds a top voice above the original theme in Var. 1 (see Example 3.6). The first Interlude is introduced after Var. 1 with relaxed and songful melody. In similar manner, further variations and interludes appear alternately to vary the original theme; significant changes of texures contribute to a perception that this piece contains many different sonorities. 
Example 3.6. Louis Gottschalk, Souvenir de Porto Rico, Variation 1, mm. 33-40.

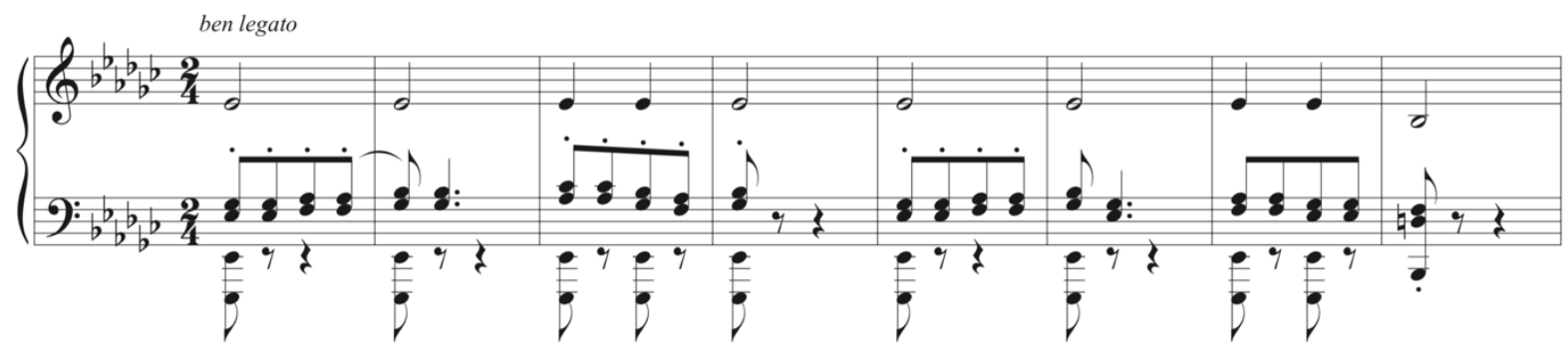

Gottschalk uses E-flat minor as the key of this piece, with a contrasting section in F-sharp major, enharmonically the relative-major key of E-flat minor. This change begins at m. 173 for Var. 6, evoking a bright and cheerful mood. The key change lasts for 29 measures of climactic passages and we return to the original key at $\mathrm{m}$. 202, starting the transition.

Throughout the variations, this monothematic piano piece uses the simple harmonic progression of the theme (see Table 3.2). This basic harmonic progression becomes less simple in the third variation through increased use of chromatics and decorative figures (see Example 3.7).$^{40}$ In the transition, significantly more complicated harmonic progressions develop the piece to its climax, followed by another variation which uses simple harmonies.

Table 3.2. Louis Gottschalk, Souvenir de Porto Rico, Harmonic progression. mm. 17-32.

\begin{tabular}{|c|c|c|c|}
\hline mm. 17-20 & mm. 21-24 & mm. 25-28 & mm. 29-32 \\
\hline $\mathrm{i}-\mathrm{i}-\mathrm{iv}-\mathrm{i}$ & $\mathrm{i}-\mathrm{i}-\mathrm{V} 7-\mathrm{V} 7$ & $\mathrm{i}-\mathrm{i}-\mathrm{iv}-\mathrm{i}$ & $\mathrm{i}-\mathrm{i}-\mathrm{V} 7-\mathrm{i}$ \\
\hline
\end{tabular}

\footnotetext{
${ }^{40}$ Maria, Gottschalk and the Caribbean, 78.
} 
Example 3.7. Louis Gottschalk, Souvenir de Porto Rico, Variation 3, mm. 85-90.

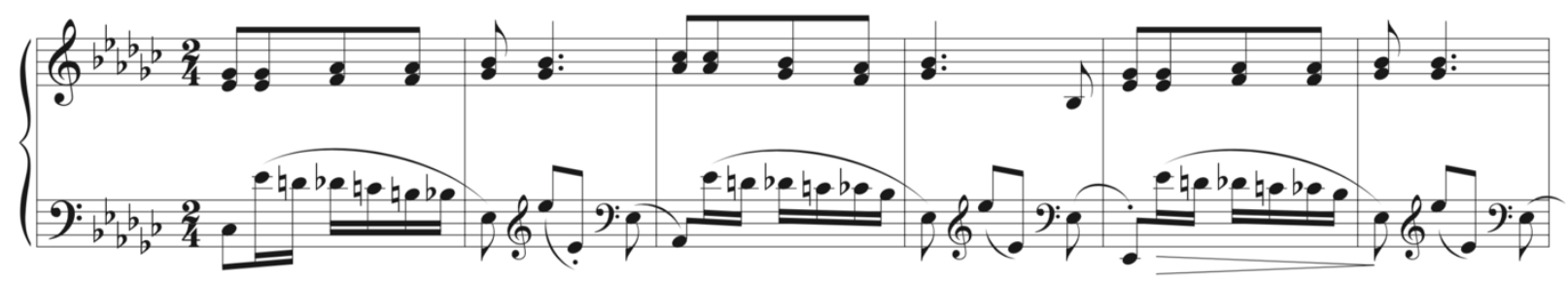

Varied dynamics provide a significant source of drama for Gottschalk in this composition. Unlike many other theme-and-variations compositions, this piece has a short developmental transition in the middle. Here, Gottschalk uses Var. 3 again, this time marked pianissimo tranquillo, in contrast to the forte we find in the original Var. 3, in effect almost creating a new variation because of the character contrast provided by the dynamic change. In this piece, Gottschalk uses a big range of dynamics, which impacts the shape of the music (see Table 3.3). For instance, very loud dynamics are used in the climactic part along with difficult techniques. Similarly, delicate passages in pp are used to fade away at the end of the piece.

Table 3.3. Louis Gottschalk, Souvenir de Porto Rico, Frequency of specific dynamic levels.

\begin{tabular}{|c|c|c|c|c|c|}
\hline$p p p$ & $p p$ & $p$ & $m f$ & $f$ & $f f$ \\
\hline 2 & 5 & 2 & 1 & 3 & 11 \\
\hline
\end{tabular}

As already mentioned, Souvenir de Porto Rico is based on Caribbean vernacular song; Gottschalk also includes Cuban rhythms in the melody. Typical Cuban rhythms used in the $19^{\text {th }}$ century included the tango, cinquillo, tresillo/conga and habanera patterns (see Example 3.8) ${ }^{41}$ His use of these Cuban rhythms greatly affects the character of this piece. The first such rhythm

${ }^{41}$ bid, 6. 
appears in the second variation, beginning at m. 59 (see Example 3.9). This syncopated rhythm in the left hand is based on the traditional Cuban rhythm called tresillo. In addition to this hemiola-flavored tresillo, habanera rhythm is also used in the right hand at $\mathrm{m} .63$ in this variation.

Example 3.8. Tango, cinquillo, habanera, and conga/tresillo rhythmic patterns.

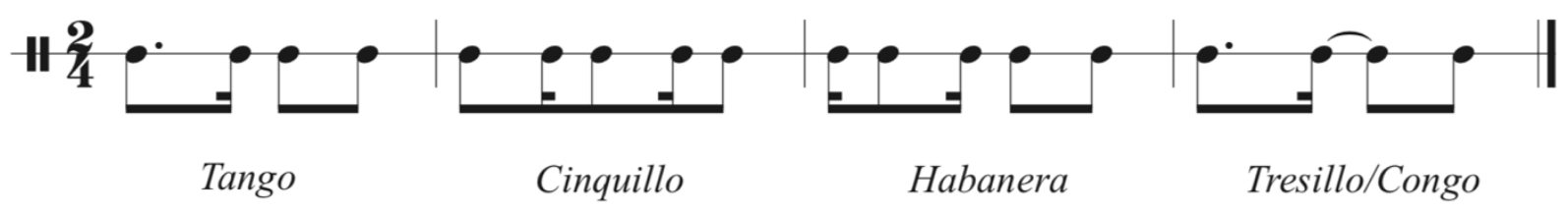

Example 3.9. Louis Gottschalk, Souvenir de Porto Rico, Variation 2, mm. 59-64.

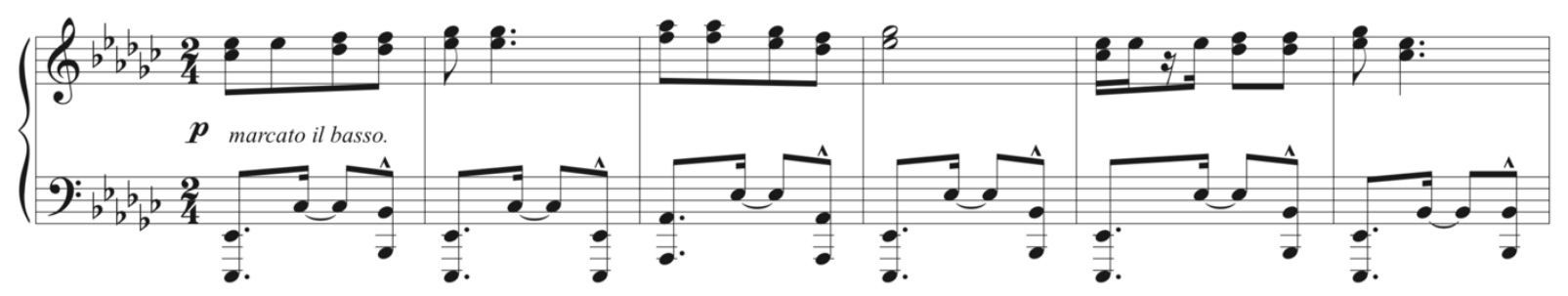

In Var. 6, at m. 174, Gottschalk uses another traditional cinquillo rhythm, presented with intense octaves in both hands (see Example 3.10). There is a short and exciting accented figure using a descending chromatic scale in tresillo rhythm in the right hand, followed by octaves in the left hand ascending in the same rhythmic pattern in m. 176 (see Example 3.10). Tango rhythm, which was also developed in Argentina and Uruguay, appears as well, in the left hand, beginning at $\mathrm{m} .173$ in this variation. 
Example 3.10. Louis Gottschalk, Souvenir de Porto Rico, Variation 6, mm. 173-178.

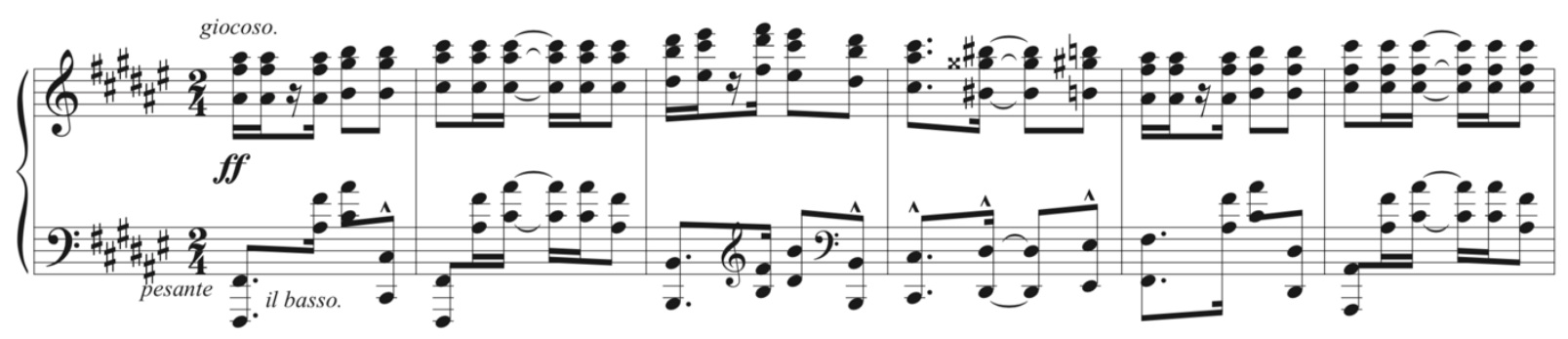

Throughout this piece, the composer employs diverse compositional styles which invite imaginative approaches. As the variations reveal differing rhythms, textures, and articulations, they call for varied sounds and techniques. At m. 49 the music seems to suggest a relaxed and rich sonority, whereas the beginning of the piece demands dark atmosphere. This diversity of articulation appears frequently in each change from the interludes to the variations. Var. 2 contains a syncopated rhythmic accompaniment with the last beat accented, creating a sort of swing-jazz feeling and almost suggesting an intoxicated mood. In Var. 3, while the right hand plays the theme at $\mathrm{m} .85$, the left hand negotiates sixteenth notes in a chromatic descending figure; when the next interlude comes at $\mathrm{m} .101$, this technique appears in both hands. This ascending and descending chromatic figure in both hands requires that the pianist understand the texture and play the music in a more flowing style. In Var. 4, the left hand is especially challenged by large and rapid leaps that cross over the right hand, all to be played leggiero (see Example 3.11). Some of the thicker and more complicated textures pose particular technical challenges for the performer. For example, the complex octave passage from Var. 5 (see Example 3.12) to the first half of the transition requires both stamina and a sure technique. By contrast, fast scale passages within a thin texture require a very different technique. Accordingly, 
this piano work demands many types of virtuosity, to accommodate Gottschalk's varied compositional styles.

Pianists need to express their most intense feelings at the climactic moment of the piece, which in this work also requires more energy than any other place in the set. This climax occurs at the sixth variation and also incorporates rhythmic complexity as the Cuban folk rhythms alternate among habanera, tango, cinquillo, and tresillo (Example 3.10 above).

Example 3.11. Louis Gottschalk, Souvenir de Porto Rico, Cross-over passage, mm. 117-122.

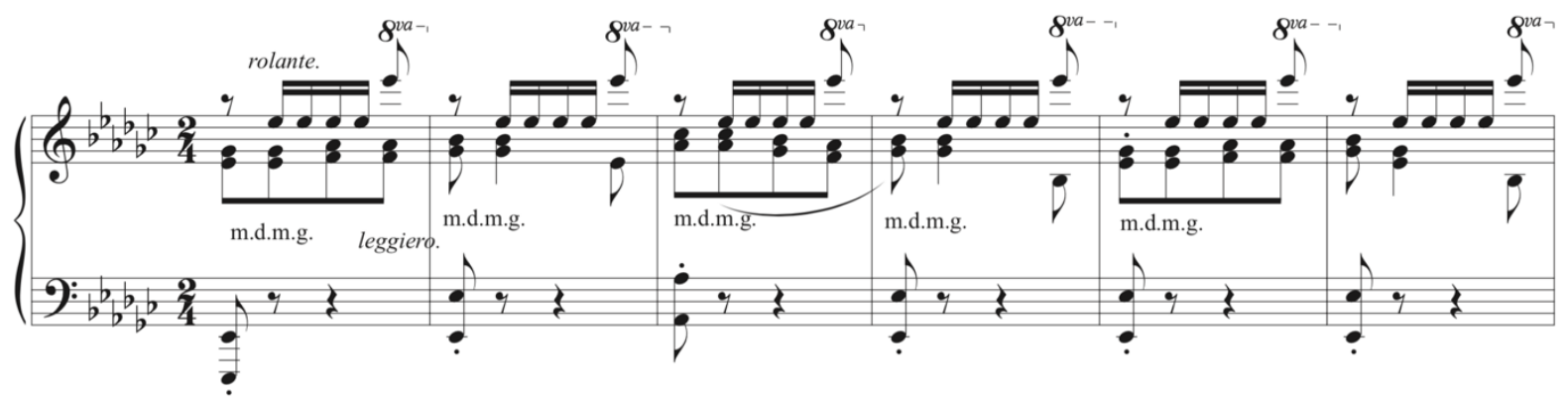

Example 3.12. Louis Gottschalk, Souvenir de Porto Rico, Octave passages, mm. 149-156.

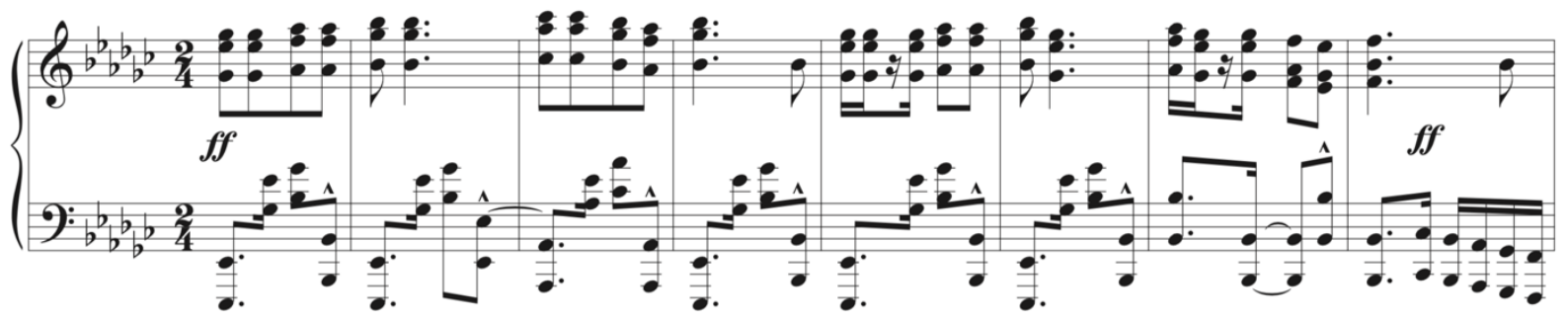




\section{Souvenir de la Havane, op. 39}

Along with El Cocoye, Souvenir de la Havane (another of Gottschalk's contradanzas and a large-scale concert piece subtitled Grand caprice de concert) focuses on variations with AfroCuban traditional rhythms. Souvenir de la Havane is divided into two main parts, which Gottschalk originally labeled Prima and Segunda; these sections are joined by an eight-bar transition which also functions as an introduction to the Segunda. The overall structure of this composition appears below (see Table 3.4).

Table 3.4. Louis Gottschalk, Souvenir de la Havane, op. 39, Structure of the music.

\begin{tabular}{|c|c|c|c|}
\hline Part & Form & Measure & Key \\
\hline \multirow{5}{*}{ Prima } & Theme A & $1-16$ & \multirow[t]{5}{*}{ Eb minor } \\
\hline & Theme A & $17-32$ & \\
\hline & Transition & $33-40$ & \\
\hline & Improvisation on theme $\mathrm{A}$ & $41-56$ & \\
\hline & Closing material & $57-66$ & \\
\hline $\begin{array}{c}\text { Transitional } \\
\text { passage }\end{array}$ & Introduction & $67-74$ & Eb Major \\
\hline \multirow{10}{*}{ Segunda } & Theme B & $75-106$ & \multirow{10}{*}{ Eb Major } \\
\hline & Var. 1 on theme B & $107-138$ & \\
\hline & Improvisation on theme $\mathrm{B}$ & $139-154$ & \\
\hline & Developmental section & $155-174$ & \\
\hline & Transition & $175-184$ & \\
\hline & Var. 2 on theme B & $185-200$ & \\
\hline & Improvisation on theme $\mathrm{B}$ & $201-211$ & \\
\hline & Var. 3 on theme B & $212-235$ & \\
\hline & Var. 4 on theme $B$ & $236-258$ & \\
\hline & Coda & $259-266$ & \\
\hline
\end{tabular}


Louis Moreau Gottschalk composed the contradanza that he called Souvenir de la Havane, op. 39, during his Caribbean travels in 1859. Aside from Cuban rural music, the most popular genre of the early $19^{\text {th }}$ century in Cuba was the contradanza. This dance music reached Cuba via Spain in the early $19^{\text {th }}$ century and Cuban composers dedicated themselves to this genre because performances of these dances in private homes or public halls provided a steady source of income for Cuban musicians. Some of the representative Cuban contradanza composers were Manuel Saumell Robredo (1818-1870), Nicolás Ruiz Espadero (1832-1890), and Ignacio Cervantes Kawanagh (1847-1905). Among them, Manuel Saumell was an absolute master of this genre and the one who introduced Gottschalk to the elegant and sensuous subtleties of contradanzas. ${ }^{42}$ These Cuban composers and their piano works will be discussed further in Chapter 4.

The original contradanza, from France and Spain, consisted of two repeated strains making four dance parts. After this genre was imported to Cuba, the figures were transformed by dancers of all ethnicities and social classes. ${ }^{43}$ Gottschalk's characteristic Romantic styles appear throughout this Cuban contradanza. This rest of this chapter will discuss aspects of this piece in the following order: Formal structure, texture, key/harmony, dynamics, rhythms, Romantic style features, and pedagogical considerations.

\footnotetext{
${ }^{42}$ Starr, Louis Moreau Gottschalk, 184.

${ }^{43}$ Ibid, 184, quoted in Argeliers León, Del Canto y el tiempo, (Havana: Editorial Letras Cubanas, 1974), 256.
} 
Example 3.13. Louis Gottschalk, Souvenir de la Havane, Theme of prima, mm. 1-8.
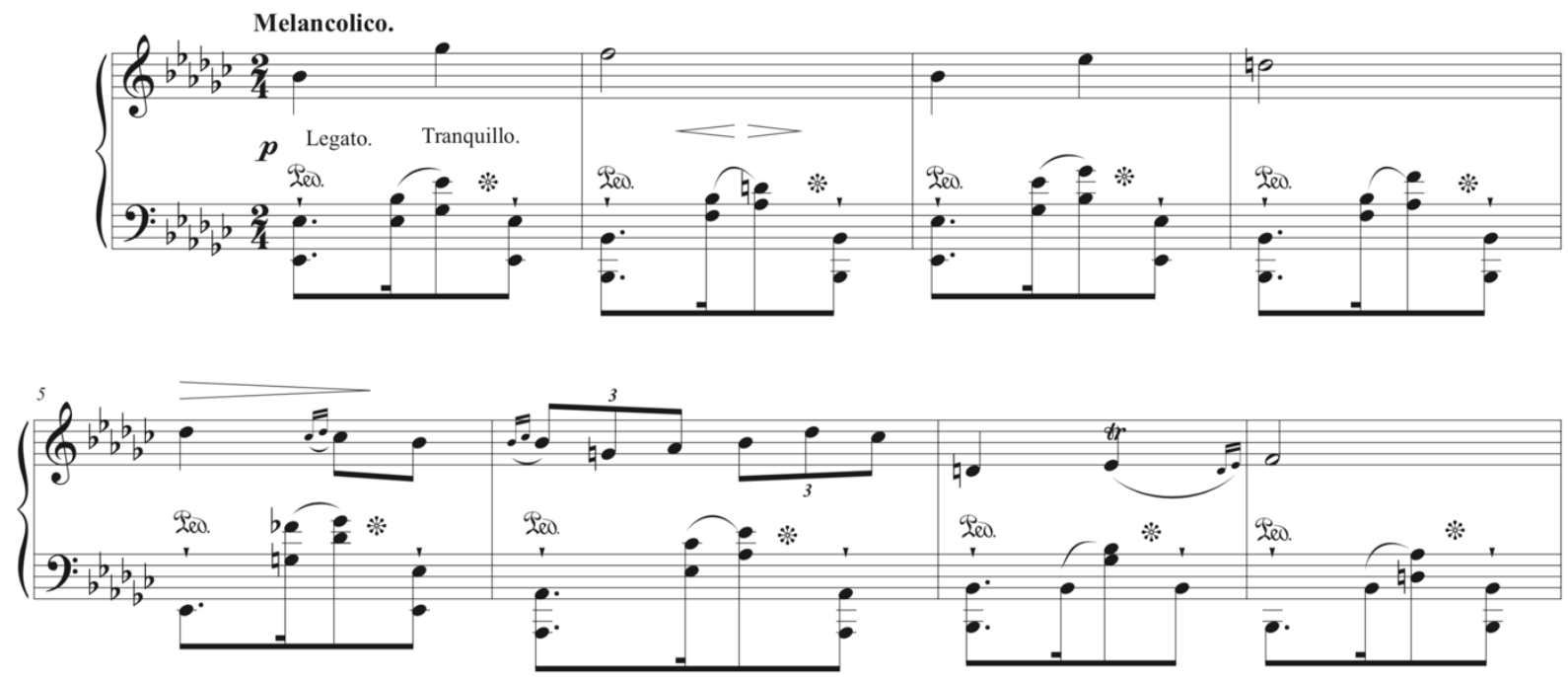

Example 3.14. Louis Gottschalk, Souvenir de la Havane, Theme of Segunda, mm. 75-82.
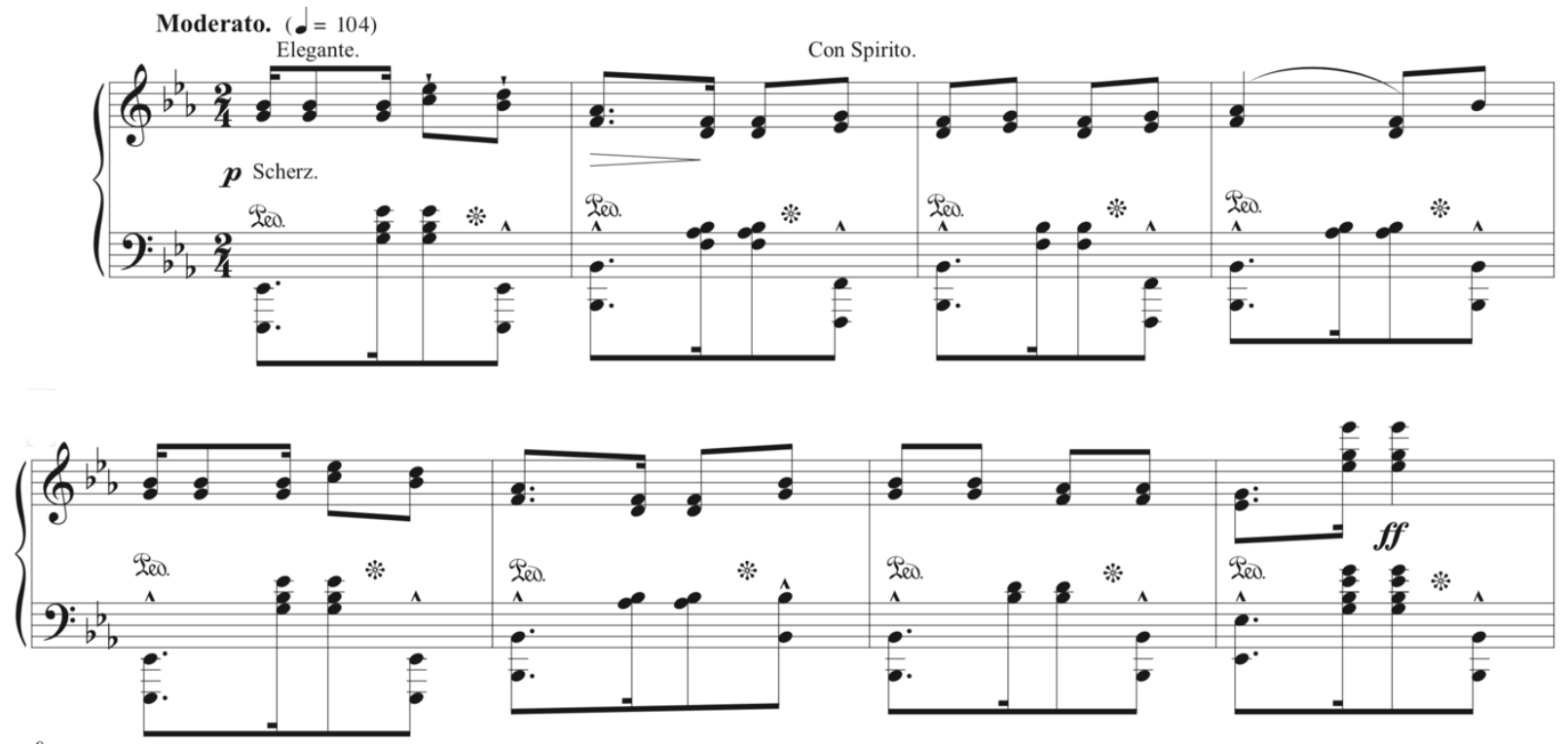

A gentle, lyrical melody in the Prima is contrasted with a playful Segunda in tango and tresillo rhythms (see Examples 3.13 and 3.14, respectively). The Prima consists of a main theme with two sets of sixteen bars that close with an authentic cadence, followed by eight bars of a transitional passage from mm. 33 to 40, followed by a prolonged main theme with improvisation, 
and finished with closing material. A new eight-bar introductory section appears prior to the Segunda at m. 67, and is accompanied with tresillo in the left hand as well as habanera rhythm in the right hand; these traditional rhythmic figures take on primary importance in the Segunda (see Example 3.15).

Example 3.15. Louis Gottschalk, Souvenir de la Havane, Introduction, mm. 67-74.
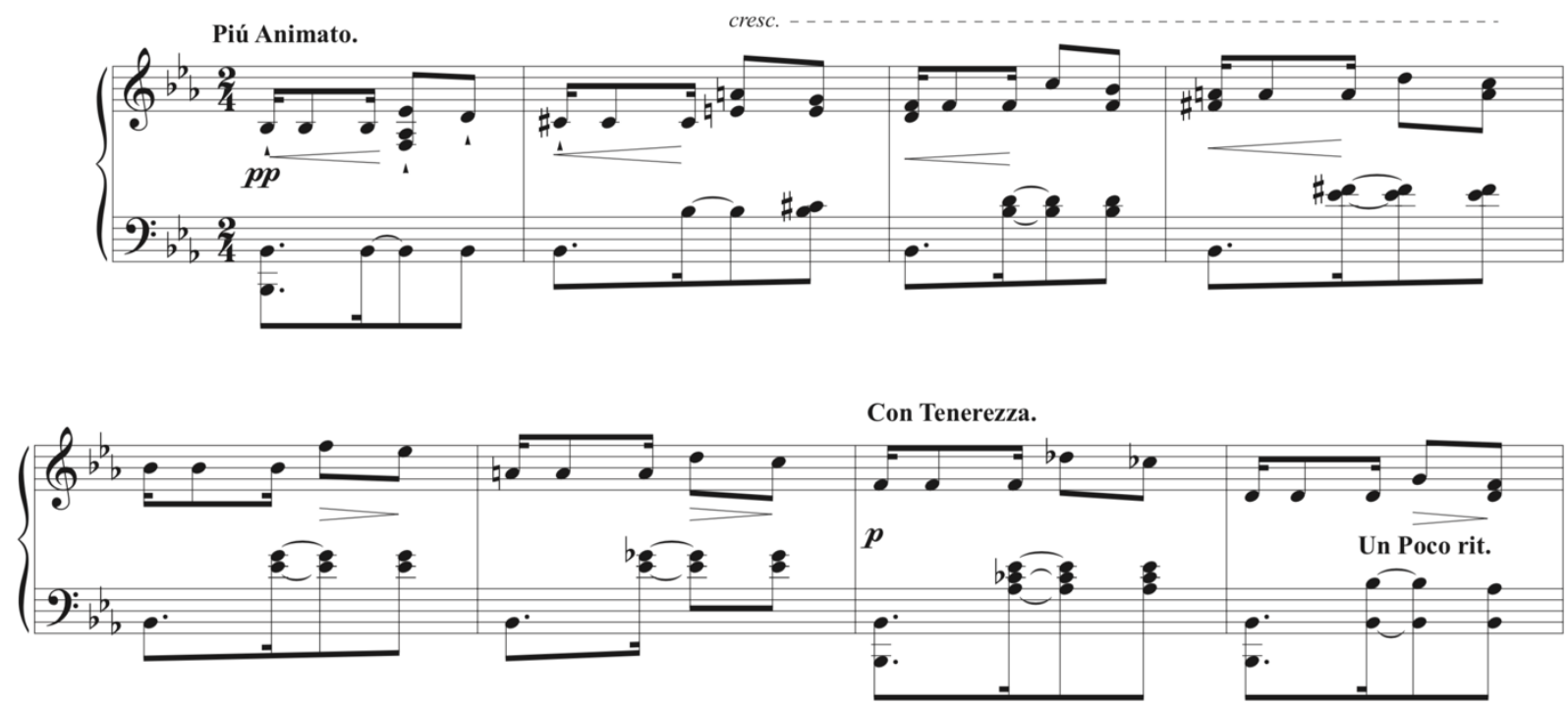

Following the transition, the first theme of the Segunda enters at m. 75; this long section connects directly to Var. 1 at m. 107. The first improvisational section enters at m. 139 and a virtuosic passage in the transition follows at m. 155. At m. 175, Gottschalk repeats the habanera rhythm with transitional harmonies during ten measures. A simpler texture for the theme appears in Var. 2, at m. 185. Another relatively plain improvisational part enters at m. 201, leading to Var. 3, in which Gottschalk utilizes a leaner texture. Finally the last variation at m. 236 runs until the coda (m. 259) in technically challenging figures as the rousing finale.

Even though Gottschalk uses variation form in this piece, his concept of not connecting each variation immediately to the next one is distinct from those of Romantic compositions such 
as Variations on La ci darem la mano by Chopin, Variations sérieuses by Mendelssohn, and Variations on a Theme of Paganini by Brahms. Instead of employing successive variations, this composition places improvisational, transitional, and developmental sections between variations, with different melody lines, harmonic progressions, accompaniment styles, and dynamic ranges.

Homophonic texture in the Prima is simply written with a melodic line in the right hand and accompaniment in the left hand supplying rhythmic energy. This texture continues until $\mathrm{m}$. 66 in the key of Eb minor. Then during the eight-measure transition to the Segunda, from mm. 67 to 74, Gottschalk uses Eb major, the parallel major of Eb minor, and a different texture, foreshadowing things to come in the Segunda (see Examples 3.14 and 3.15). While the Segunda contrasts with the Prima in texture and key, Gottschalk generally maintains homophonic styles in the Segunda as well.

Gottschalk begins this piece in Eb minor. However, at m. 67, the mode changes to Eb major, continuing in this key until the end of the piece. According to the indication at the beginning, the piece starts legato and tranquillo; the key of Eb minor seems appropriate as well for the melancholic mood. During the transition the chord progressions in Eb major are fastmoving and unstable, marked "Più Animato" until the arrival of the second theme at m. 75 . Theme and variations follow in the Segunda and the piece closes in Eb major. In addition to simple use of the two keys, his chord progressions in each key are also simple except the transitional, developmental sections; this concept is common among other pieces in the same era.

Like many other composers of his time, Gottschalk employs a great range of dynamics in this piece as a whole. The overall dynamic of the Prima is piano, and the added "tranquillo" and "elegante" expressive terms describe a sweet and melancholic feeling. In contrast to this, a big dynamic range from pp to fff appears in the Segunda. In particular, fff occurs at several places to 
emphasize the most passionate moments of the piece. For instance, the improvisational section at m. 139 increases the tension until the climactic moment in fff at m. 154 (see Example 3.16).

Example 3.16. Louis Gottschalk, Souvenir de la Havane, Improvisation on the theme B, mm.

$139-154$.
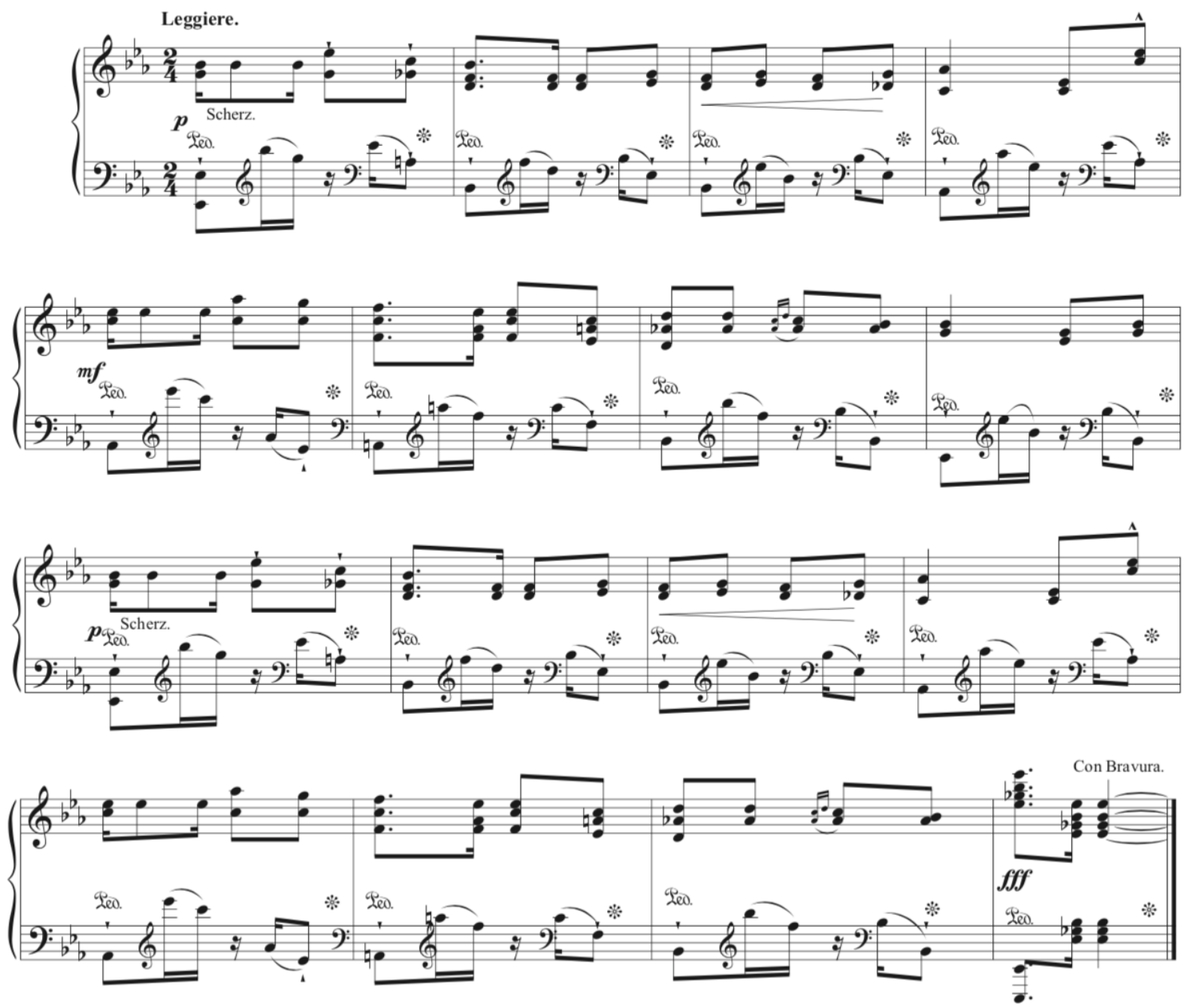
Rhythm, and rhythmic layers, remained a fundamental element in Gottschalk's Caribbean works. These works are deeply influenced by African-derived rhythms, including the habanera, tresillo, and cinquillo; these rhythms are used as ways to vary the theme. Gottschalk usually uses one rhythm pattern for the two hands, but occasionally combines patterns to have two contrasting rhythms at the same time. He also juxtaposes triplets against duple figures at several places in the Prima (see Example 3.13) which gives a relaxed feeling. Furthermore, the tresillo rhythm first appears in the left hand, coming against the right hand's habanera figure in m. 67.

Gottschalk was celebrated not only in the Caribbean islands, but also in Western Europe and North America. Even though his Creole-influenced New Orleans style brought him a good reputation, his fusion of European Romantic traditions with the Latin figures in his compositions is another great achievement. His Souvenir de la Havane provides a fine example.

Souvenir de la Havane shares many characteristics with compositions by Romantic composers in the $19^{\text {th }}$ century, such as song-like melodies, chromatic figures, pedal point, dynamic contrasts, and great technical virtuosity. The lyrical parts of this composition have indications such as melancolico, elegante, ben cantato (well-sung), con tenerezza (with tenderness), and leggiero. Furthermore, Gottschalk's use of chromatic figures in the third variation is also typical of Western European Romantic-era compositions. He prominently employs pedal point to convey the sound of a ringing bell at the beginning of the piece, and he includes pedal point in most of the variations. Another notable Romantic compositional technique found in this piece is the use of layers of texture in virtuosic parts and a big range of dynamics. In his piano compositions Gottschalk frequently uses consecutive octave patterns to build up to the climactic point as displayed in Souvenir de la Havane (see Example 3.17). This technique also appears in El Cocoye, as shown in Example 3.18. 
Example 3.17. Louis Gottschalk, Souvenir de la Havane, mm. 158-160.

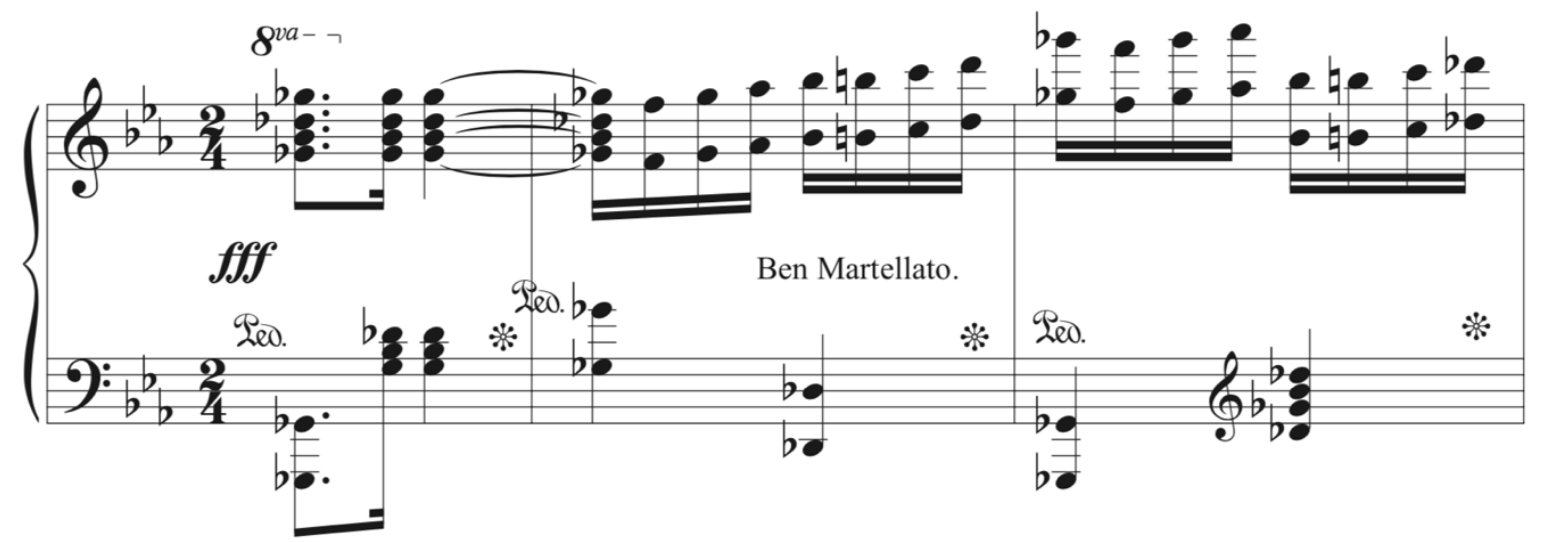

Example 3.18. Louis Gottschalk, El Cocoye, mm. 271-273.

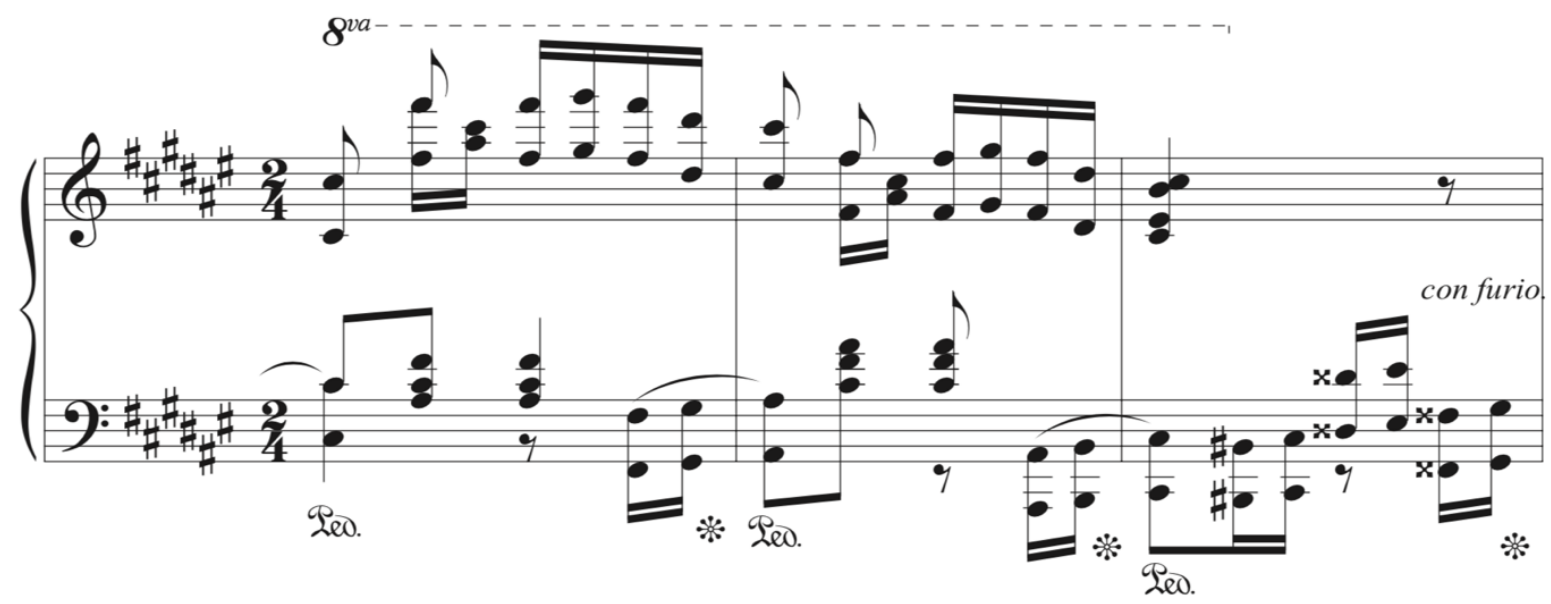

Throughout this piece, the composer employs Romantic features which challenge the performer's creative imagination. As the two repeated dance forms reveal contrasting themes, rhythms, textures, and articulations, they call for varied moods and techniques. This piece contains a syncopated rhythmic pattern overall, creating a sort of swing-jazz feeling and almost suggesting an intoxicated mood. Gottschalk also uses variations on a simple theme in the Segunda and the material becomes more complicated as the number of notes and leaps increases. For instance, Var. 3 demands a more flowing style because it consists of sixteenth notes in 
chromatic and arpeggio figures. The irregular figures in the left hand require that the pianist understand the texture and produce even sounds. In Var. 4, the right hand is especially challenged by large and rapid leaps to high "B" during 23 measures (except E-flat and A-flat in the last two bars), along with continuing melody lines produced by both hands. This piece also contains a developmental section at $\mathrm{m}$. 155 , which is particularly challenging technically for the performer, as the extended octave passages require both stamina and a sure technique. Since the Cuban folk rhythms continue throughout the piece, above all the performer should be aware of opportunities for interpretive variety in tempo, texture, articulation, rubato and dynamics between and within the Prima and the Segunda.

There is no evidence that Gottschalk quotes themes from folksong in this composition; nonetheless, Souvenir de la Havane is rhythmically and melodically characteristic of the music of Cuba and Puerto Rico. We cannot be sure whether the themes of this composition were genuine folk melodies because of the scarcity of published research on the folk music of the islands. ${ }^{44}$ Regardless of whether Gottschalk uses actual Cuban folksong in this piece or not, Souvenir de la Havane is a remarkably flavorful Afro-Cuban piano piece that also includes Romantic features throughout.

\footnotetext{
${ }^{44}$ Dolye, The Piano Music of Louis Moreau Gottschalk, 167.
} 


\section{Cuban Influences on Gottschalk}

Cuban music was significantly influenced by African culture. This infusion began with the arrival of slaves after Cuba became a Spanish-dominated country in the early $16^{\text {th }}$ century. After pianos were first brought by Europeans in the 1790s, at first only wealthy people could afford pianos for entertaining. The instruments later became more popular, which meant that local composers could use them to create their works. The increasing popularity of the instrument also meant that Cuban composers wrote more piano pieces. As a result, Cuban pianists were able to perform local pieces along with the popular European genres, especially from Spain and France, that audiences loved. Indeed, along with many genres for piano, Cuban composers extended their repertoire to symphonies, operas, and concertos. ${ }^{45}$

Many representative compositional techniques for Cuban composers derived from European music traditions, which they combined with traditional Cuban folk materials in a similar way to Gottschalk's compositions in Cuba. One of the composers who utilized this technique is Manuel Saumell Robredo (1818-1870), who was recognized as the first Cuban nationalist composer due to his famous contradanzas. The contradanza was a popular genre internationally in the $18^{\text {th }}$ century, derived from English country dance, which had been popular since the late 1500s. In the following century the genre spread to France, the Netherlands, and elsewhere in continental Europe. From the 1850s on, some composers, including Robredo and

\footnotetext{
${ }^{45}$ Steffan Eugene Panos, "THE ROLE OF THE PIANO IN AFRO-CUBAN JAZZ," (M.M. thesis, University of California, Riverside, 2002).
} 
also Ignacio Cervantes Kawanagh (1847-1905), wrote contradanzas intended as light Classical piano works for the salon rather than the ballroom. ${ }^{46}$

Most contradanzas, however, were written and used for dance accompaniment at the ballrooms. The Cuban contradanza consists of two parts: Either an eight-bar section followed by a 16-bar second part, or 16 bars followed by 16 bars. In most Cuban contradanzas, the distinctive Creole character resides in the rhythms, especially the habanera rhythms of the bass. Saumell's El bazar is the typical 16-plus-16 Cubanized contradanza, using Classical style in the first part, followed by the second part in Creolized Cuban folkloric style, with the tango pattern in the left hand and the habanera pattern in the right hand (see Example 3.19). ${ }^{47}$

\footnotetext{
${ }^{46}$ Peter Manuel, "From Contradanza to Son: New Perspectives on the Prehistory of Cuban Popular Music," Latin American Music Review, 30, no. 2 (2009): 184-212.

${ }^{47}$ Ibid, 79-83.
} 
Example 3.19. Manuel Saumell Robredo, Contradanza 'El Bazar.'
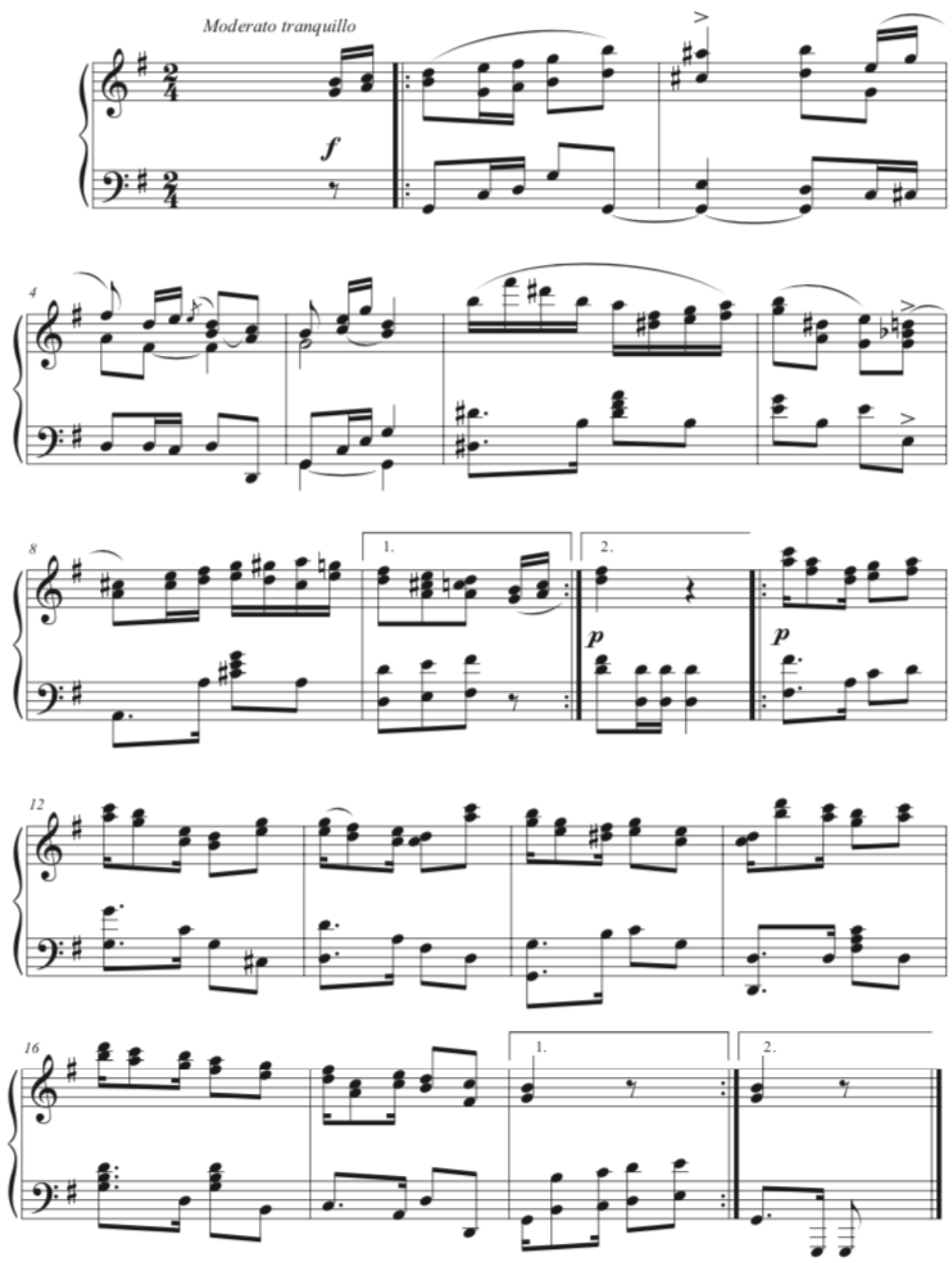
Over the years, every major Cuban composer was to dedicate at least one contradanza to Gottschalk, as Gottschalk was a very influential composer in Cuba. Gottschalk, in turn, wrote at least seven contradanzas, and dedicated them to his pianist-composer friends. ${ }^{48}$

Gottschalk's seven contradanzas:

Grand caprice de concert: Souvenir de la Havane, El Cocoye

Caprice: Vamos a la azotea

Danse cubaine: Di Qui Si, Ojos Criollos, La Gallina

Danza: Ineswas

Saumell is the one above all who introduced Gottschalk to the elegant and sensuous subtleties of the contradanza, which was used as an example for Gottschalk's Cuban folkloric contradanzas. The last of Saumell's 50 contradanzas was dedicated to his friend Gottschalk. ${ }^{49}$

Nicolás Ruiz Espadero (1832-1890) was another influential composer and pianist for Gottschalk in West Indies. Gottschalk and Espadero had a special relationship not only as friends, but also as comrades in the music field. Espadero used much less local music tradition than some other famous Classical Cuban composers such as Juan Edelmann, Saumell Robredo, and Ignacio Cervantes. He had been influenced by bravura piano music since he was young and his compositions for piano, such as piano trio, scherzo, sonata, and various character pieces clearly reveal the influence of Classical European music traditions, even though he never left Cuba to study in Europe. Instead of using folk material, he recasts this music of Havana into the language of Chopin, Liszt, and Gottschalk. ${ }^{50}$ Starr considers Espadero "the most original in

\footnotetext{
${ }^{48}$ Starr, Louis Moreau Gottschalk, 184.

${ }^{49}$ Shari Akua Williams, "Ignacio Cervantes and his Forty Danzas in the Context of Nineteenth Century Cuban Nationalism,” (M.A. thesis, University of Calgary, 2016).

${ }^{50}$ Starr, Louis Moreau Gottschalk, 174.
} 
either Spain or Cuba in the nineteenth century." ${ }^{.51}$ Espadero's Romantic virtuosic techniques in the music differ from those of many Cuban composers in his generation who followed the traditional Cuban materials. His Ballade, op. 57, is one example of his compositions which was composed in the manner of European Romantic composers in the $19^{\text {th }}$ century. Gottschalk also composed several Ballades, including op. 85 and op. 87 , in an act of fealty toward his idol and Espadero's, Chopin. Their Ballades all are marked by expressive melodic lines and a total absence of Caribbean flavor. ${ }^{52}$ In this way, Gottschalk was not only musically influenced by Cuban composers' compositional style, but he also influenced them.

Gottschalk was respected by many Cuban composers not only because of their interactions, which produced great results as their music combined multiple cultures, but also the contributions he made to Cuban music by recruiting pianists and composers still known to us today, including Nicolás Espadero (1832-1890), Fernando Aristi (1828-1888), Ignacio Cervantes (1847-1905), and Pablo Desvernine (1823-1910) ${ }^{53}$ His knowledge of European classic tradition, obtained during his time in Paris, was treated as very valuable in Cuba, and many Cuban composers admired him and his music. Following his legacy, much music by these composers is associated mostly with Western Europe. Cuban piano music in the $19^{\text {th }}$ century was fairly receptive to new traditions from France and Spain, due to the fact that Cuban elite made regular pilgrimages to Paris whence they brought back the ethnic tastes that reigned in the French capital.

\footnotetext{
${ }^{51}$ Ibid, 176.

52 Ibid, 297.

${ }^{53}$ Ibid, 176-179.
} 
As there are many works dedicated to Gottschalk by Cuban pianists and composers, such as Saumell's wistful Recuerdos de Gottschalk and Espadero's Elégie sur la tombe de Gottschalk, ${ }^{54}$ Gottschalk was certainly regarded as an admired pianist and composer in Cuba even though his compositions were not all entirely from the Cuban idiom.

${ }^{54}$ Ibid. 438. 


\section{Chapter 4}

\section{Darius Milhaud}

\section{Biography}

Darius Milhaud (1892-1974) was one of the most influential French composers in the $20^{\text {th }}$ century. His works are not as well known as those of earlier French composers such as Debussy, Ravel and Satie; however, in a different way, his new musical ideas were just as worthy as theirs. Like most composers of his generation, his early music was influenced by Debussy and Ravel; but his musical path followed the group Les Six, known for the development of polytonal compositions. Milhaud was particularly inspired by Eric Satie (1866-1925), who was the group's mentor and mascot. ${ }^{55}$ Of the more than 400 compositions by Milhaud, most were composed in France, where he spent much of his life, though some of his works were written in Brazil or the United States. His time spent outside France was an important window for acquiring information from the outside world. ${ }^{56}$

Darius Milhaud was born in Aix-en-Provence in 1892 and raised in a Jewish family. At an early age, he started studying music with various instruments including piano. Milhaud was surrounded by Classical music early on, since his family were amateur musicians who played chamber music at home. With the support of his family, Milhaud was accepted into the Paris Conservatory in 1909 as the youngest student ever. During his conservatory years, he was recommended as an outstanding student in Xavier Leroux's harmony class, Charles-Marie

\footnotetext{
${ }^{55}$ Deborah Mawer, Darius Mailhaud: Modality and Structure in Music of the 1920, (England: Scolar Press, 1997).

${ }^{56}$ Gao, "Discussion About Darius Milhaud and His Work," 63.
} 
Widor's fugue class and Paul Dukas's orchestra conducting class. By his own admission, though, Milhaud was not good with traditional harmonic language and showed slow progress in Leroux's class. However, when Milhaud finally obtained permission to play his first Sonata for Violin and Piano (1911) for Leroux, he was advised to pursue his own, already developed, harmonic idiom. $^{57}$

He eventually decided to stop studying violin in order to devote himself entirely to composition and he soon acquired a good reputation as a composer. In addition to his professional studies in Paris, Milhaud liked the strong artistic atmosphere of Paris at the time, where he had the opportunity to watch theater genres such as ballet and opera. During this period, Milhaud interacted with many people who inspired him. Among them were composers Erik Satie (1866-1925), Arthur Honegger (1892-1955), Georges Auric (1899-1983), Germaine Tailleferre (1892-1983), litterateurs Jean Cocteau (1889-1963), Paul Claudel (1868-1955), Francis Jammes (1868-1938), and the writers Francis Jammes and Paul Claudel, both of whom later collaborated with him as librettists. ${ }^{58}$ These composers and writers later inspired Milhaud's life and his music when he returned to France from Brazil. While his musical career in Paris was productive as a composer for the theatre, orchestra, chamber music, voice, and piano, he was not given a chance to submit his music for the Prix de Rome, one of the major competitions for composers, due to World War I.

\footnotetext{
${ }^{57}$ Darius Milhaud, Notes Without Music, (New York: Alfred. A. Knopf, 1953), 32.

${ }^{58}$ Market House Books, ed., Who's Who in the Twentieth Century, (Oxford University Press, 2003), https://www.oxfordreference.com/view/10.1093/acref/9780192800916.001.0001/acref-9780192800916 (accessed July 24, 2019).
} 
After the war, Milhaud had opportunity to visit Brazil as a secretary for his friend Paul Claudel, who was appointed French Minister to Brazil in 1916. In Rio de Janeiro, Milhaud was attracted not only to the tropical climate, but also to the folk and popular songs that he heard. He expressed his feeling about Brazil as "in this marvelous country," and "in contact with the great tropical forest." During this period, folk rhythms and melodies inspired Milhaud and opened his mind and ears to new ideas; this experience provided the inspiration for such works as the two dance suites known collectively as Saudades do Brasil (1920-1921), which evoke a folk-like atmosphere. ${ }^{59}$ In addition to this piano composition, Milhaud collaborated with Claudel on a Brazilian ballet, L'homme et son désir (1918). Although he stayed in Brazil for only a short time, this experience definitely had a great impact on his musical outlook in the new compositional style he discovered during this period; in other words, his music was influenced by his environment. To explain the music in Brazil, Milhaud wrote:

I was fascinated by the rhythms of this popular music. There was an imperceptible pause in the syncopation, a careless catch in the breath, a slight hiatus that I found very difficult to grasp. So I bought a lot of xexes and tangos and tried to play them with their syncopated rhythms, which run from one hand to the other. At last my efforts were rewarded and I could both play and analyze this typically Brazilian subtlety. ${ }^{60}$

Along with Brazilian folk elements, jazz became another musical idiom for Milhaud after 1920. His first exposure to jazz was in New York, where he experienced the authentic jazz music

\footnotetext{
${ }^{59}$ Marion Bauer, "Darius Milhaud,” The Musical Quarterly 28, No. 2 (1942): 139-159, https://academic.oup.com/mq/article-abstract/XXVIII/2/139/1167374? redirectedFrom=fulltext (accessed Nov 3, 2019).

${ }^{60}$ Milhaud, Notes Without Music, 75.
} 
of African Americans on the streets of Harlem. Later, while in London, he was given the chance to hear this genre once again. Eventually he decided to use jazz elements in his compositions. One example is La Création du Monde (1923), depicting the creation of the world as reflected in African mythology. He explained his feeling about jazz:

The music I heard is totally different from any music I have previously heard, it is an enlightenment for me. Set off by each drum beat, the melody part progresses by a breathtaking, uneven and intertwined rhythmic pattern in a crisscrossed way ...the effect resulting from this music was so huge to me that I could not bear to leave. ${ }^{61}$

Upon his return to France, Milhaud joined the group Les Six, which had already existed informally. Germaine Tailleferre was the first member of the group after she entered the Paris Conservatory in 1906; two others, Arthur Honegger and Georges Auric, connected with Tailleferre at the school in 1911 and 1913. The three other members, including Milhaud, Francis Poulenc, and Louis Durey, also joined the group and formed their identity. They were, in fact, introduced as Les Six by critic Henri Collet who wrote an article entitled "Russes, Les Six Français et Erik Satie" and compared them with the Russian composer group known as the The Five. These six composers opposed both Debussy's Impressionism and Wagner's idiom; instead, they desired to establish a traditional French music. Along with the other group members in Les Six, Eric Satie mentored Milhaud both in music and also in life. Although Eric Satie was a friend of Debussy, he strongly opposed Debussy's music because he felt it broke the traditional rules of French music. Under the influence of Satie, the musicians in Les Six felt unified in aiming to be the composers for traditional French music. In this period between 1920 and 1930, Milhaud

\footnotetext{
${ }^{61}$ Gao, "Discussion About Darius Milhaud and His Work," 64.
} 
gained international fame through his many compositions, not only because of his association with Les Six.

His experimental works composed after the 1930s were favorably accepted. Milhaud dedicated himself to composing works in new musical genres such as incidental music, film score, and jazz. Due to the war in France in 1940, he fled to the United States, where he served on the music faculty of Mills College in Oakland, California. ${ }^{62}$ He wrote several short piano compositions during this time, including Choral (Hommage à Paderewski) (1941); La libertadora, op. 236 (1943); and Une journée, op. 269 (1946).

In 1947 Milhaud returned to the Paris Conservatory as a faculty member. He spent alternate academic years at Paris Conservatory and Mills College until 1971, when he moved to Switzerland to retire from his academic musical life. ${ }^{63}$ Milhaud passed away on June 22, 1974, after completing his last three works, which were the part-song Ani Maamin, String Quartet Etude, and Wind Quintet. ${ }^{64}$

\footnotetext{
${ }^{62}$ Mary Jane Rupert, The piano music of Darius Milhaud: A survey, 5-6.

${ }^{63}$ Ronald Crichton, "Darius Milhaud,” The Musical Times 115, no. 1578 (1974): 684-685.

${ }^{64}$ Gao, "Discussion About Darius Milhaud and His Work," 65.
} 


\section{Compositional Style of Milhaud's Piano Works}

Many Post-romantic composers had a marked preference for the instrument that was cherished by Schumann, Chopin, and Liszt. ${ }^{65}$ Even during his lifetime, Milhaud was known as one of the most prolific French composers, with a unique compositional style. Based on his professional music education since childhood, he was able to compose numerous works for varied genres such as winds, vocal, string, ballet, opera, film music, and piano. His piano works, in fact, are only a few, in contrast to his works in other genres. Compared to other French composers in his generation, such as Debussy or Ravel, just a few of his piano compositions, including Saudades do Brasil, have been researched and performed by musicians globally. Nevertheless, his musical language, as reflected in the piano compositions, is well worth exploring.

Just as many French composers in his generation wrote piano works within their own unique musical styles, Milhaud also followed his own pathway for his piano works. However, his piano compositions differ significantly in style depending on the period, his inspiration, and the geographical location wherein he composed. Bauer believes that Milhaud achieved a wider range of styles and moods than any other of his contemporaries, except perhaps Stravinsky. ${ }^{66}$

Milhaud composed over 50 keyboard works for organ, piano solo, two pianos for four hands, and one piano for four hands. The following section will focus on some of the influences and styles we can trace in Milhaud's piano compositions, including: Francis Jammes and Paul

\footnotetext{
${ }^{65}$ Paul Collaer, Darius Milhaud, (Genève: Slatkine, 1982), 184.

${ }^{66}$ Bauer, "Darius Milhaud," 143.
} 
Gaudel, Debussy, polytonality/bitonality, Satie and Stravinsky, Neoclassicism, invertible counterpoint, jazz, Latin American elements, and programmatic music.

Two of the most potent influences during his early period were not musicians; they were the writers Francis Jammes and Paul Gaudel. Milhaud often collaborated with them and, in the process, helped to establish himself as a composer of theatrical works. Nevertheless, he also devoted himself to instrumental music including piano. His early piano works were inspired by French composers Franck, Fauré, and eventually Debussy; he held Debussy in especially high esteem among them. It is arguable whether Milhaud was inspired by Debussy because the French composers Les Six stood against Impressionistic composers' music; but his early piano music still followed some of Debussy's style to make dreamy music by using techniques such as chromaticism, pedal point, non-traditional scales, arpeggiated accompaniments, ambiguous harmonies and tonal centers, rich chords, etc. Gradually, though, his musical style grew more distinct from Debussy's in his later works. Collaer believes that Milhaud consciously used less coloristic effect and more polyphony, whether polytonal or polymodal. Consequently, his later piano music contained less sonorous ambiguity ${ }^{67}$

According to Bauer, Milhaud later said, "I sought a robust music, I wished to avoid the mannerisms of outworn idioms, of pastel shades and sentimental harmonies. I had a horror of useless detail and of unnecessary developments. I always orchestrated with the ear and not the eye." ${ }^{68}$

Nearly all of Milhaud's piano compositions are works of considerable interest and most of them are grouped into cycles, each of which has a different subject: the seasons, the hours of

\footnotetext{
${ }^{67}$ Collaer, Darius Milhaud, 185.

${ }^{68}$ Bauer, "Darius Milhaud,” 144.
} 
the day, family life, religious festivals, etc ${ }^{69}$ His first piano composition, Piano Suite, op. 8, was written in 1913. Later, he mentioned that this work no longer satisfied him and he did not like it to be played. ${ }^{70}$ Regardless, this work is a proper example that shows Debussy's influence, including an ostinato bass figure (see Example 4.1), chromaticism (see Example 4.2), and polytonal harmonies used in conjunction with lyrical melodies. This early work consists of five parts and is one of the large-scale pieces among his piano compositions, perhaps with less inventiveness of diatonic melodies than we see in later works.

Example 4.1. Darius Milhaud, Piano Suite, op. 8, no. 1, mm. 1-9.
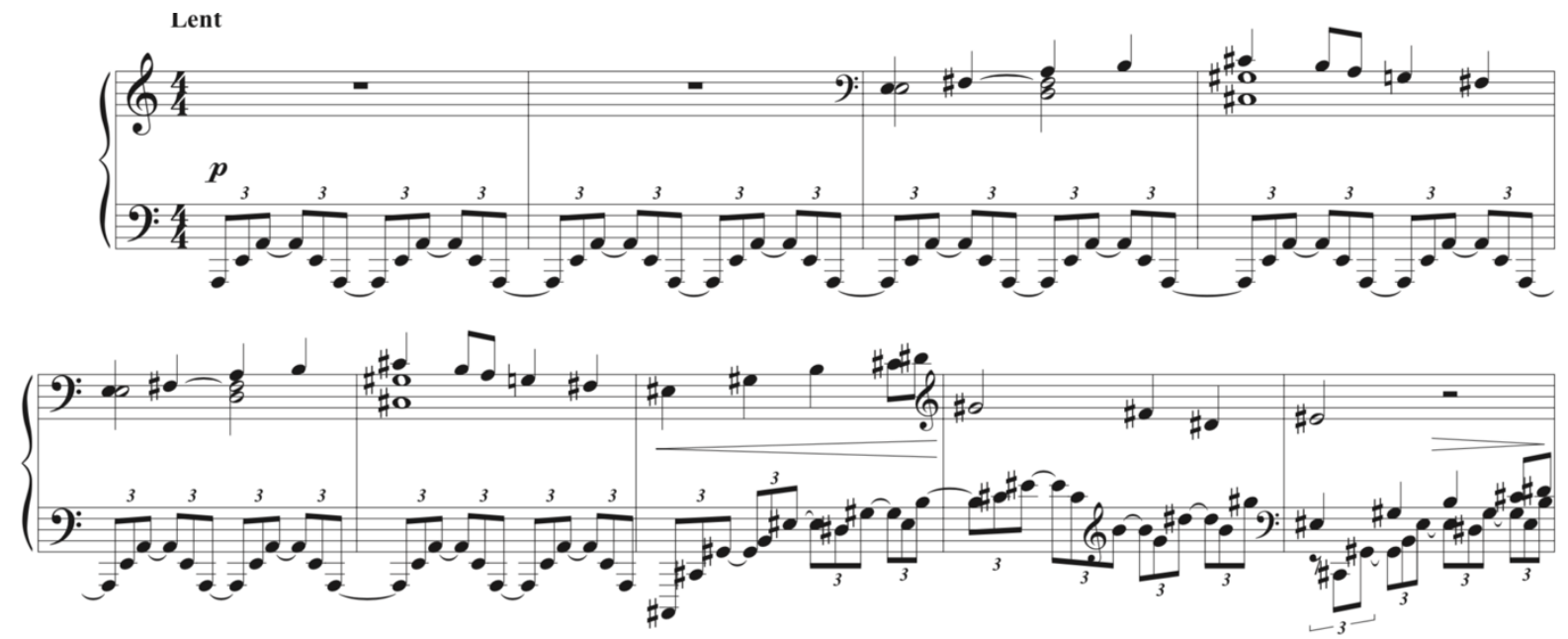

${ }^{69}$ Collaer, Darius Milhaud, 185.

${ }^{70}$ Darius Milhaud, My Happy Life, (New York: Marion Boyars Publishers, 1995), 60. 
Example 4.2. Darius Milhaud, Piano Suite, op. 8, no. 3, mm. 10-13.
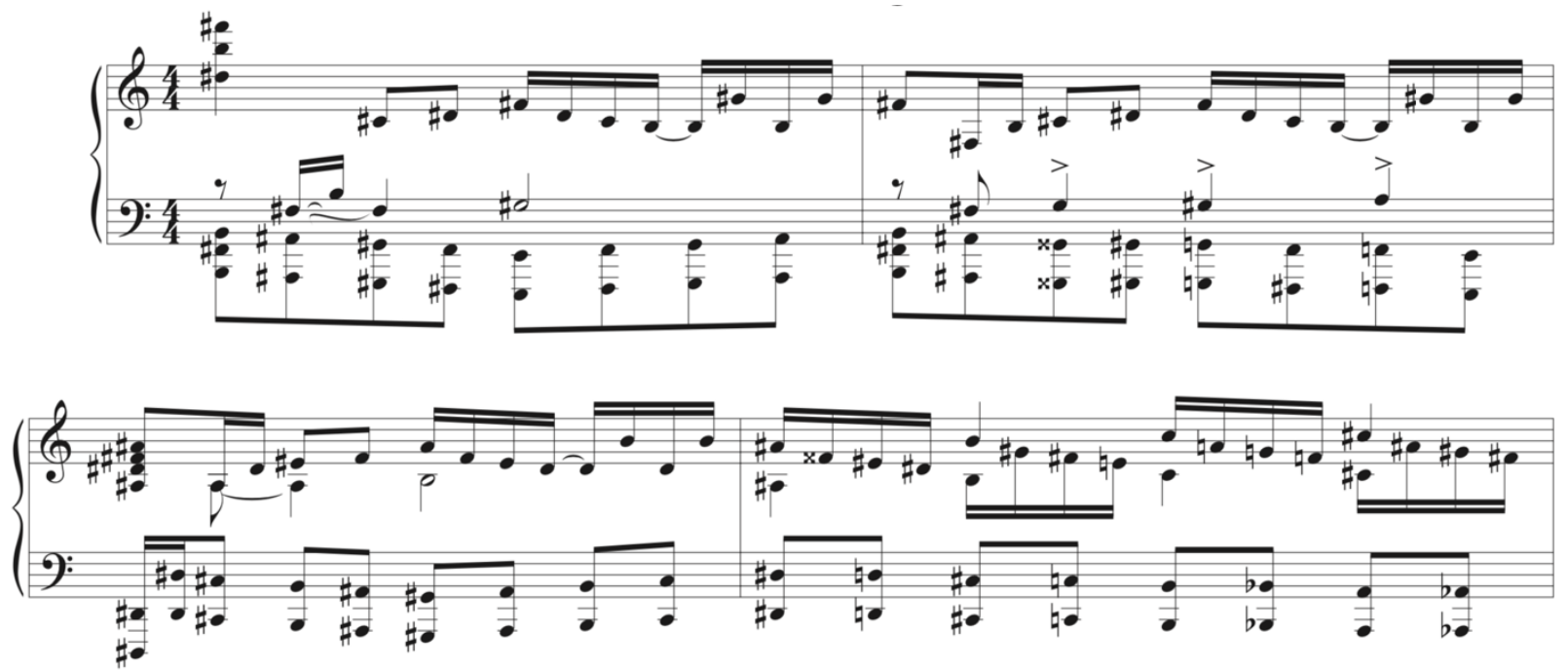

In addition to the Piano Suite, op. 8, in 1914 he composed Mazurka, which also reveals similarity with Debussy's musical idioms. This short 37-bar piece is based on a melodydominated homophonic texture and gently performed horizontal passages with a whole-tone scale in the right hand and rolling figures in the left hand (see Example 4.3). In addition to these techniques, his use of frequent pedal points and parallelisms also support the idea that Milhaud's early works are under the influence of Debussy. 
Example 4.3. Darius Milhaud, Mazurka.
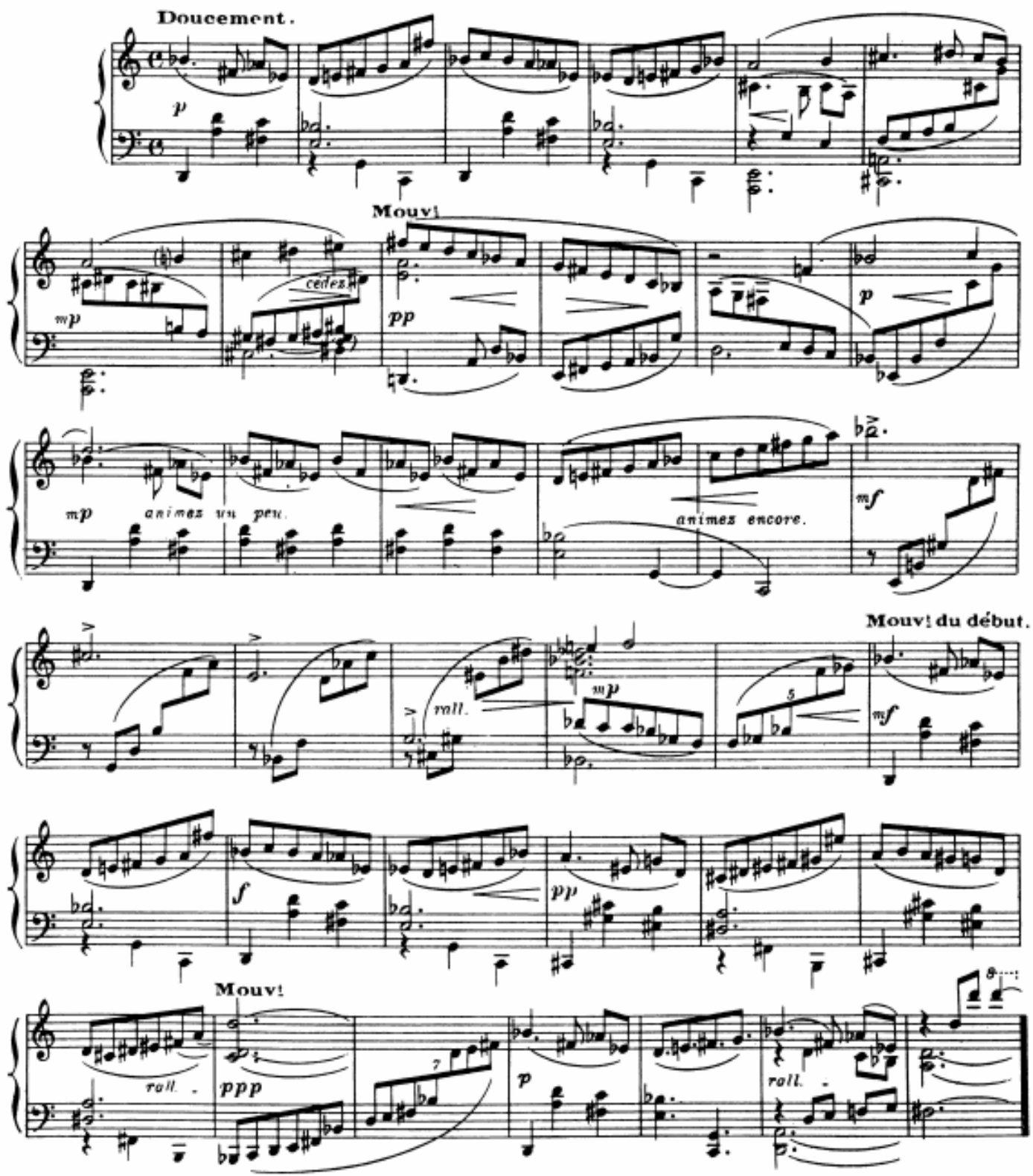
In addition to Debussy's idioms, among the best-known compositional features that Milhaud employed in his piano works are polytonality and bitonality; these functions greatly affect the "atmosphere" of the music. This trait was popular in this period, and Stravinsky's The Rite of Spring, in particular, is remembered as a striking example of the use of bitonality. Notable Milhaud piano works which contain this technique include Piano Sonata No. 1, op. 33 (1916), and Saudades do Brasil, op. 67, along with many more examples in his later works. His frequent use of bitonality/polytonality contributes significantly to mood evocation in these pieces. $^{71}$

It is not surprising to find that he also used different styles simultaneously in individual pieces, such as alternating sections that are polytonal with those that are not (example:

Scaramouche, 1st Movement) or diatonic passages contrasting with highly chromatic material (example: Piano Suite, op. 8). As previously mentioned, Milhaud was a composer of many styles, whereas many others were labeled as Romantic composers or Impressionistic composers.

Although some of his early piano compositions show that he was inspired by Debussy, he also held Eric Satie and Igor Stravinsky in high regard and he consciously emulated their compositional styles. Satie's French ideals of clarity, precision, simplicity and transparency were attractive to Milhaud and this influence pervaded his piano compositions. As a result, Milhaud's simple and articulated music with light texture is similar to that of Satie. Stravinsky was also a huge inspiration to Milhaud for music which uses simple lines in the melody and more than two tonalities.

Stravinsky's Neoclassicism was also a decisive influence on Milhaud. Stravinsky's music reflects many styles from earlier periods, as does Milhaud's. According to Stuckenschmidt, in a

\footnotetext{
${ }^{71}$ Lee, A Study on the Discriminative Elements, 12.
} 
conversation between Arnold Schoenberg and Anton Webern, they agreed that Stravinsky's imitation of Bach in his Piano Sonata (1924) demonstrates clear evidence of Neoclassicism. ${ }^{72}$ Interestingly, Stravinsky's other piano sonata, which was written in 1904, is completely opposite to the later work in that it provides intensive Romantic musical features throughout the piece. Indeed this shift in style from Romanticism to Neoclassicism was taken by many composers. Milhaud also dedicated himself to this movement and followed its style points such as clarity and precision, thus renewing the tradition of Scarlatti and Mozart and reflecting awareness of Baroque and Classical principles. ${ }^{73}$

Invertible counterpoint is one of the Neoclassical aspects Milhaud used in his piano compositions. For example, the second piece in Printemps, Book I, op. 25 (1915-1920) presents this technique over polytonal figures. It also shows the simplicity he was aiming for, as well as his use of dissonant sounds. His use of invertible figuration presents at mm. 4 and 16 while two parts play the same melody (see Examples 4.4 and 4.5). In other parts of this work he uses more complex rhythms and harmonies. Collaer observes that this piece also resembles the spirit of Mendelssohn's Songs Without Words, with a similar spontaneity and guileless quality. ${ }^{74}$

\footnotetext{
${ }^{72}$ Hans Heinz Stuckenschmidt, Arnold Schoenberg: His Life, World and Work, (London: John Calder, 1977), 39.

${ }^{73}$ Mawer, Darius Mailhaud: Modality and Structure, 12.

${ }^{74}$ Collaer, Darius Milhaud, 185.
} 
Example 4.4. Darius Milhaud, Printemps, Book I, op. 25, no.2, mm. 4-9.
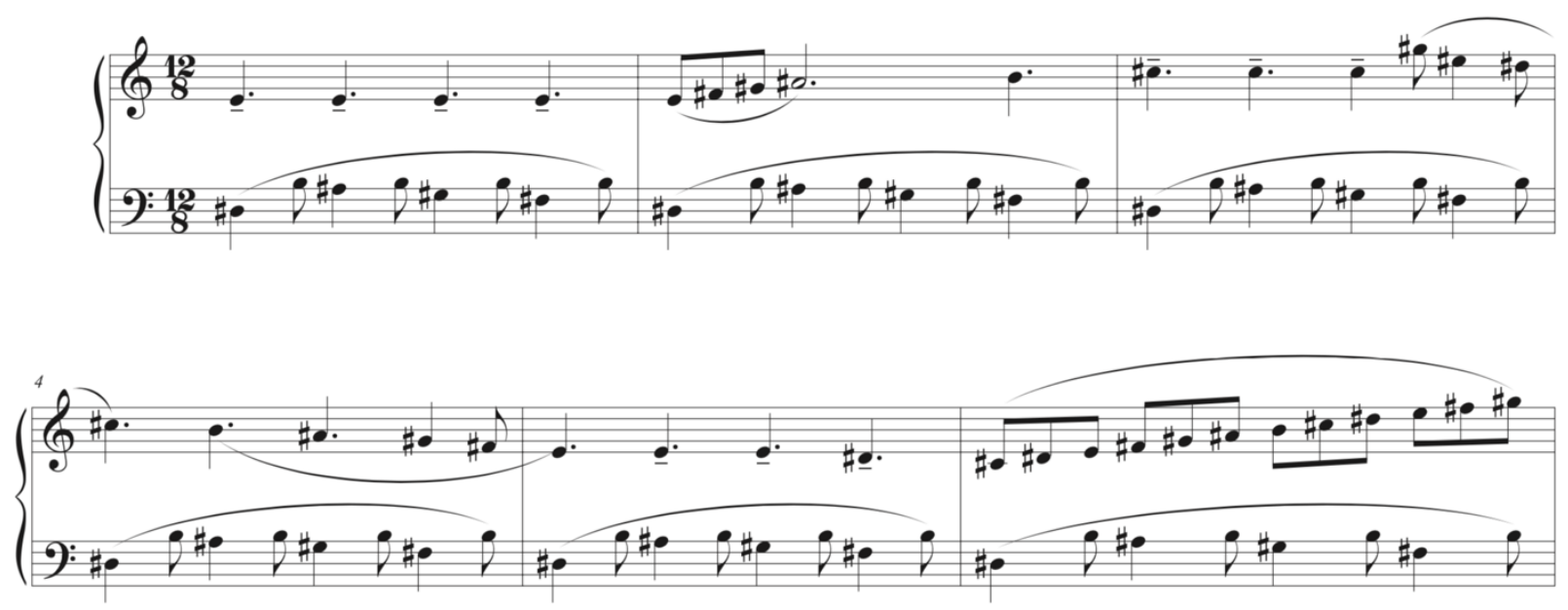

Example 4.5. Darius Milhaud, Printemps, Book I, op. 25, no.2, mm. 16-11.
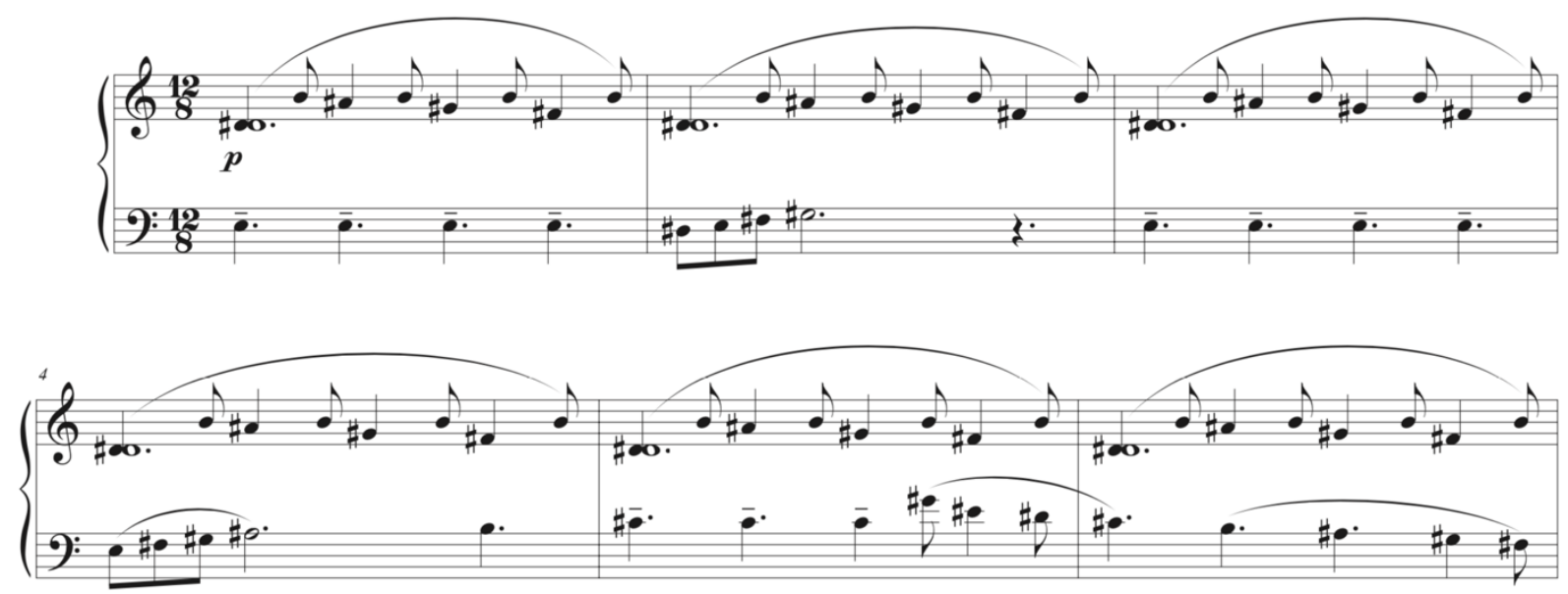

Neoclassical elements are generally considered to be one of Milhaud's musical signatures. On the other hand, his jazz-influenced piano works are sometimes not regarded as being characteristic of his musical idiom. Nevertheless, Milhaud loved jazz and the piano was the perfect instrument to achieve his jazz legacy. His jazz-inspired piano compositions included 
Caramel Mou, op. 68 and Trois Rag-Caprices, op. $78 .^{75}$ Both pieces show his intense interest in American jazz, using energetic syncopated rhythms and walking bass. Not only did Milhaud use jazz elements, but he also added his own unique polytonal flavor. These compositions were written in the early 1920s, when he was in New York and had opportunity to listen to AfricanAmerican jazz.

While many of his works display elements that are associated with early RomanticImpressionist works or with jazz or Neoclassicism, some of his most interesting piano music falls under the influence of Latin America. Two of his pieces that are representative in this category are Tango des Fratellini, op. 5, and Saudades do Brasil, op. 67. In these two works, Milhaud conveys the Latin flavor with popular folk melodies and rhythms over light dissonances. In particular, his well-known piece Saudades do Brasil, which will be discussed further in the next chapter, presents a variety of Brazilian folk rhythms, mixed with his own fully developed polytonality. ${ }^{76}$

Like many other composers in his generation, Milhaud adopted programmatic titles and characteristics in his piano works, including the following pieces:

L'Automne, op. 115 (1932) (three pieces), 4 Ésquisses (4 Sketches), op. 227 (1941), La muse ménagère, op. 245 (1944) (15 pieces, also orchestrated)

These imaginative works reflect Milhaud's personal experiences and many of his compositional styles are expressed through these works. Above all, L'automne, a suite for piano in three movements, showcases his rich sonorities in a Romantic musical style with such features

\footnotetext{
${ }^{75}$ Mawer, Darius Milhaud: Modality and Structure, 120-125.

${ }^{76}$ Lee, The solo piano music of Darius Milhaud, 44.
} 
as long pedal, recurring diatonic scales, big ranges of dynamics, and frequent use of the higher registers. The first movement, Septembre, refers to the time of Milhaud's visit to Portugal, and the second, Alfama, is a delightful and tuneful depiction of an ancient section of Lisbon, where a celebration in honor of the Congress took place. The last piece's name is Adieu, and describes a nostalgic farewell. 4 Ésquisses (Four Sketches) and La muse ménagère are considered late works, in which many of his other innovative techniques appear. For 4 Ésquisses, his use of habanera and rhumba elements evokes the Latin flavor, especially through the piece Alameda, which was dedicated to Aaron Copland. This four-movement piano work was later rearranged into four different versions: for orchestra, for woodwind quintet, for clarinet and piano, and for piano solo. The last piece in this category, La muse ménagère, is a humorous work, depicting the time that Milhaud and his wife experienced when they lived in the United States and had to get by without servants. It includes 15 short pieces with silly titles such as Household Care, Cooking, Flowers in the House, Laundry, and Fortune Telling, etc. Each piece has its own characters and moods, displaying a variety of compositional techniques. ${ }^{77}$

In conclusion, although many of Milhaud's piano compositions reveal elements from different musical styles, Neoclassicism is the core stylistic component of his piano music. It can be argued that many of his works in other styles are also Neoclassic-influenced music, but he gradually moved to a Neoclassical focus through his entire compositional life.

\footnotetext{
${ }^{77}$ Ibid, 49-59.
} 


\section{List of Piano Works by Milhaud}

Year Title

1931 Suite, op. 8

1914 Mazurka; published in L'Album des (1920)

1915 Variations sur un thème de Cliquet, op. 23

1916 Sonata No. 1, op. 33

1919 Printemps, Book I, op. 25

1920 Printemps, Book II, op. 66

1920 Caramel Mou, op. 68; also arranged for voice and jazz band

1921 Saudades do Brasil, op. 67; 12 pieces; also orchestrated

19223 Rag-Caprices, op. 78); also orchestrated

1930 Choral, op. 111

1932 L'automne, op. 115

1933 L'album de Madame Bovary, op. 128b; after the film music Madame Boyary, op. 128

19333 Valses, op. 128c; after the film music Madame Bovary, op. 128

19334 Romances sans paroles, op. 129

1933 Promenade (Le tour de l'exposition), op. 162

1941 Touches blanches, Easy Pieces, op. 222 No. 1

1941 Touches noires, Easy Pieces, op. 222 No. 2

1941 Choral (Hommage à Paderewski)

19414 Ésquisses (4 Sketches), op. 227; also orchestrated and for wind quintet

1943 La libertadora, op. 236; also for 2 pianos

1944 La muse ménagère, op. 245; 15 pieces; also orchestrated

1946 Une journée, op. 269

1947 Méditation, op. 277

1948 L'enfant aime, Suite A Child Loves, op. 289

1948 Accueil amical, 17 Pieces for Children, op. 326

1949 Sonata No. 2, op. 293

1950 Jeu, op. 302; published in the album Les contemporains

1951 Le candélabre à sept branches, op. 315

1948 Accueil amical, 17 Pieces for Children, op. 326

1954 Hymne de glorification, op. 331

1956 La couronne de Marguerite (Valse en forme de rondo), op. 353

1956 Sonatina, op. 354

1956 Le globe-trotter, op. 358; 6 pieces; also orchestrated

1957 Les charmes de la vie (Hommage à Watteau), op. 360; also orchestrated

1970 Six danses en trois mouvements, op. 433; also for 2 pianos

\section{Piano 4 hands}

1919 Le bœuf sur le toit, op. 58a; after the ballet

1920 Enfantines, Suite after 3 poèmes de Jean Cocteau, op. 59a; 3 pieces

\section{Pianos}

1937 Scaramouche, Suite, op. 165b; after the incidental music Le médécin volant, op. 165

1943 La libertadora, op. 236a; 5 pieces; also for piano 
1943 Les songes, op. 237; 3 pieces; after the ballet, op. 124 (1933)

1944 Le bal martiniquais, op. 249; 2 pieces; also orchestrated

1947 Carnaval à la Nouvelle-Orléans, op. 275

1948 Kentuckiana, divertissement sur 20 airs du Kentucky, op. 287; also orchestrated

1970 Six danses en trois mouvements, op. 433; also for piano

\section{Pianos}

1948 Paris for 4 pianos, op. 284; also orchestrated 


\section{Saudades do Brasil}

Saudades do Brasil, op. 67, written for solo piano in 1920, illustrates the inspiration Brazilian dance music brought to Milhaud. "Saudade" translates literally as "missing" and the piece depicts the nostalgia Milhaud felt upon recalling his experiences in Brazil. In its depiction of Brazilian culture, this work is the most obviously ethnic-flavored piano composition of Milhaud and is influenced by the music of Brazilian composer Ernesto Nazareth. ${ }^{78}$ These pieces, which were dedicated to Milhaud's friends and colleagues, are comprised of two sets of six tangos, with the titles of individual movements taken from districts within Rio de Janeiro:

Group 1: Sorocaba, Botofago, Leme, Capacabana, Ipanema, Gravea

Group 2: Corocovado, Tijuca, Sumare, Paineras, Laranjeiras, Paysandu

The original version was composed in 1920 for solo piano and Milhaud orchestrated it with an added overture one year later. Moreover, some of the movements have been arranged for other solo instruments such as violin, cello, flute, and saxophone with piano accompaniment. The première was given by pianist Nininha Velloso-Guerra at a Concert des Six in the Galérie Montaigne on November 21, $1920 .^{79}$

The background story is that in 1917 Milhaud travelled to Rio de Janeiro as a secretary to Paul Claudel, who had been appointed as the French minister to Brazil. Milhaud was immediately attracted by the Brazilian traditional folklore. In his autobiography My Happy Life, he describes his feeling about Brazilian popular music and the composer Nazareth:

\footnotetext{
${ }^{78}$ Mawer, Darius Milhaud: Modality and Structure, 116.

${ }^{79}$ Lee, A Study on the Discriminative Elements, 43.
} 
My first contact with Brazilian folklore was very sudden. Rio was in the middle of Carnival, and I immediately sensed the mood of crazy gaiety that possessed the whole town..........I was intrigued and fascinated by the rhythms of popular music which has imperceptible pause in the syncopation, a careless catch in the breath, a slight hiatus......... One of the best composers of this kind of music, Nazareth, gave me deeper insight into the Brazilian soul with his elusive and mournful playing. ${ }^{80}$

This work draws from some of the same features as many of his piano works that are regarded as Neoclassical compositions. Milhaud uses more complicated harmony and his signature bitonality/polytonality, but within simpler structures. Each piece has its own characteristics based on tango rhythms and each has its own tempo marking and expressive directions. In Collaer's descriptions, we find elegance in Sorocaba, tenderness in Leme, and brilliance in Ipanema, while Gavea explodes in rhythm and shattering harmonies before settling into amiable nonchalance. The final Paysandu is "a serene meditation." 81

These pieces are fascinating for their formal structures, textures, keys, and harmonies, along with their folk melodies and rhythms. Each of these 12 pieces is in duple time and has no key signature. Most reveal ABA form, with slight variations. This simple ternary structure also appears in Milhaud's jazz-inspired works, such as Trois rag-caprices (1923). For contrast, Milhaud divides some pieces into more sections, which are relatively shorter. For instance, Corcovado consists of seven sections (ABACABA) that create a seven-part rondo, with tonal contrasts among the parts. For example, in $\mathrm{m} .9$ the right-hand part appears in a new tonality above the continuing left-hand part (see Example 4.6). Milhaud sometimes employs a third relationship from the tonal center for the B section for his ternary-structure pieces. In Sorocaba,

\footnotetext{
${ }^{80}$ Milhaud, My Happy Life, 70-71.

${ }^{81}$ Collaer, Darius Milhaud, 185.
} 
at m. 21 Milhaud uses $\mathrm{G}$ minor, which is a third lower than Bb minor, the starting key of the piece (see Example 4.7).

Example 4.6 Darius Milhaud, Saudades do Brasil, Corcovado, mm. 1-14.
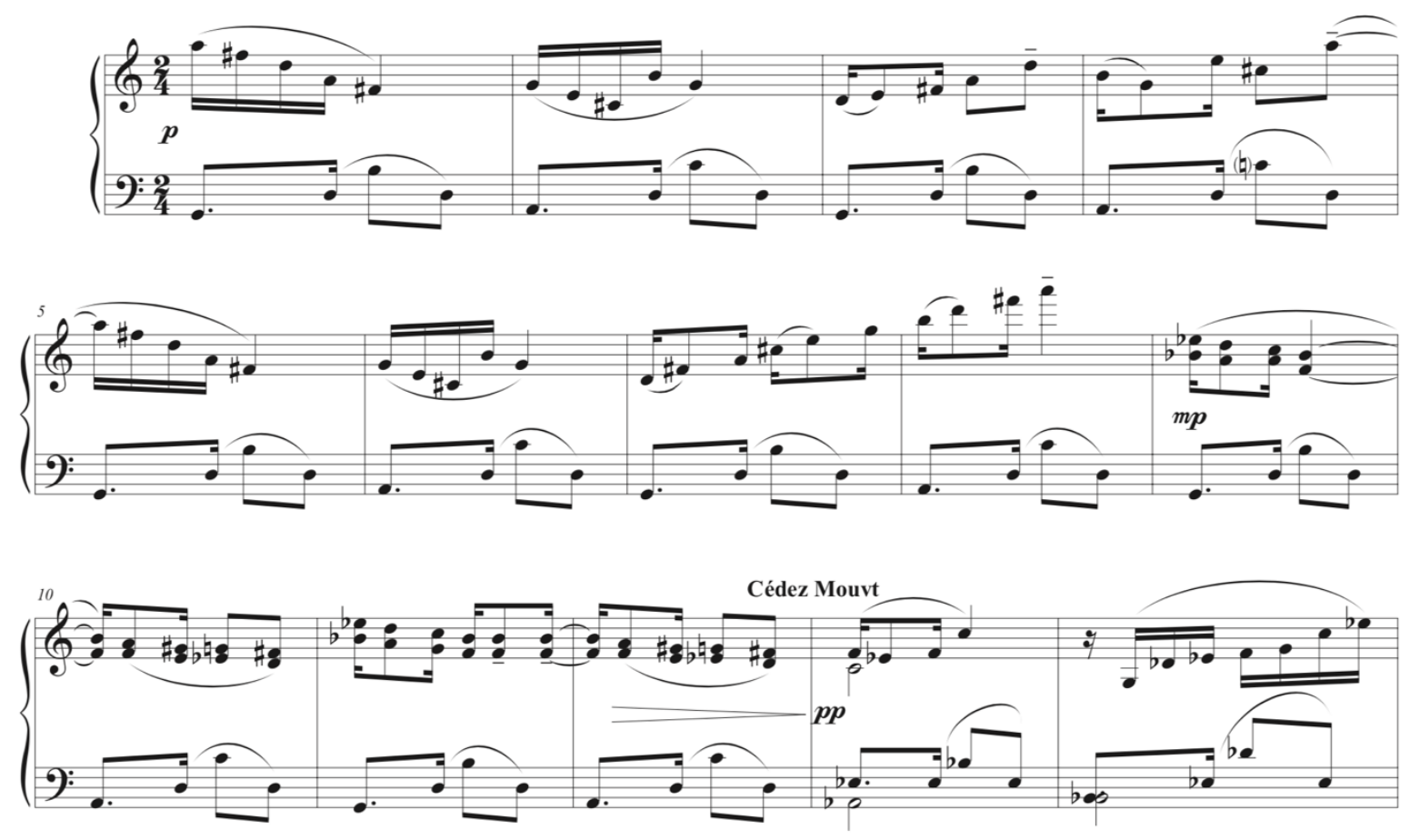
Example 4.7 Darius Milhaud, Saudades do Brasil, Sorocaba, mm. 1-4, 21-24

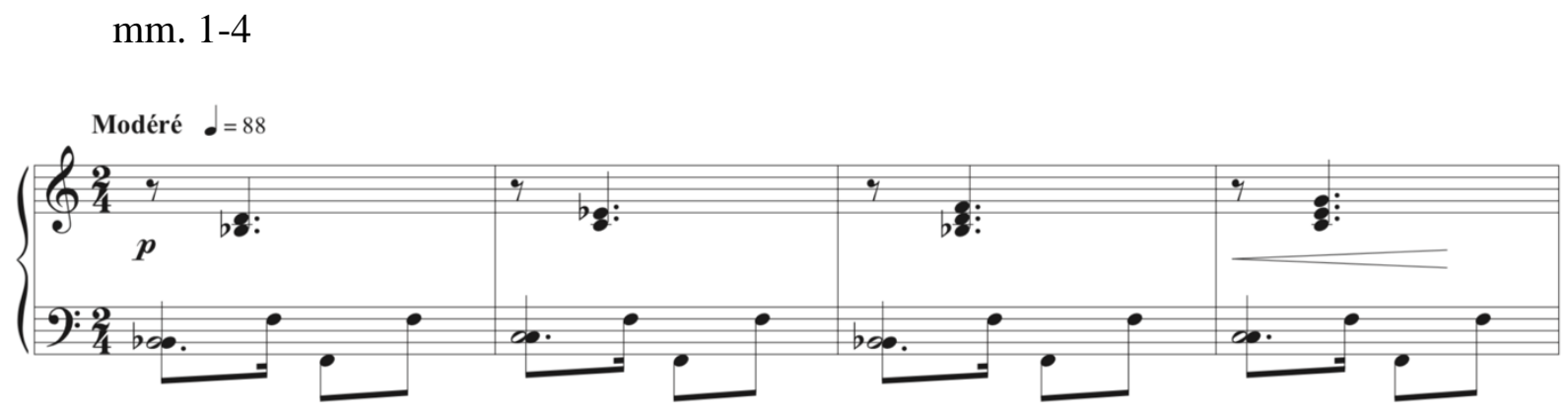

mm. 21-24

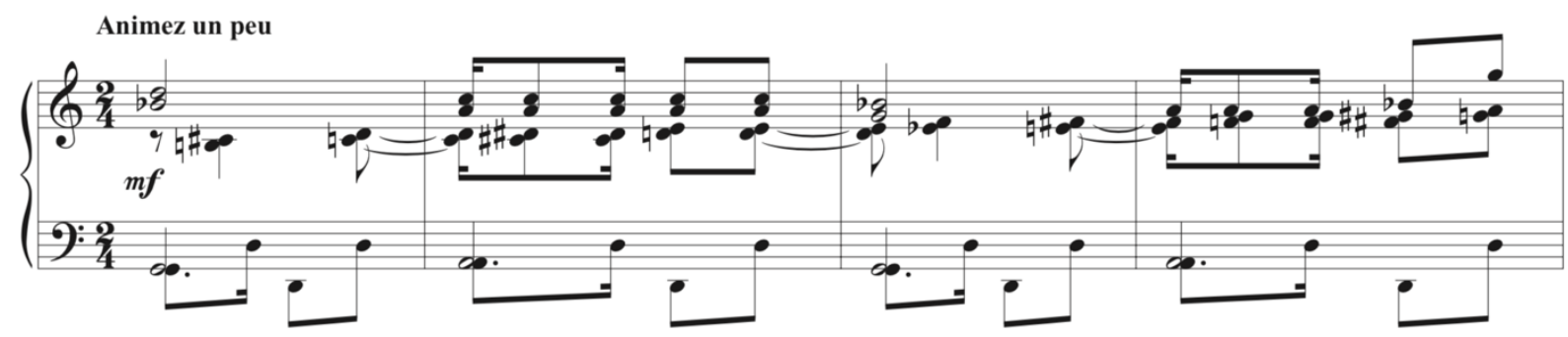

While some of the pieces are divided into a small number of parts (e.g., ABA) by contrasting rhythmic patterns, textures, and melody lines, others cannot easily be categorized into a "typical" formal structure. For example, the fourth movement, Copacabana, is clearly five parts (ABCA'B) and shares three themes indirectly. No matter how Milhaud divides the sections in each piece, the overall forms are relatively clear. To achieve this, he uses key relationships and harmonies to distinguish the sections in the piece, along with changing the textures.

Milhaud composes this work in a simple melody-dominated homophonic texture. The recurring patterns in the bass, which are present almost everywhere from the beginning to the end of each piece, give a stable and balanced feeling. The melodies, which are original by Milhaud but partially inspired by Ernesto Nazareth, appear mostly in the top voice. The texture that Milhaud chooses here helps to convey a lyrical and songful feeling. 
Bitonality/polytonality, which was mentioned briefly in the previous chapter, is mainly associated with early $20^{\text {th }}$ century composers such as Stravinsky, Bartok, and Charles Ives. Two famous examples of works using bitonality/polytonality are Stravinsky's ballets The Rite of Spring and Petrouchka. The following excerpt shows C major and F\# major appearing simultaneously in Petrouchka (see Example 4.8).

Example 4.8 Igor Stravinsky, Petrouchka, Petrouchka’s room, mm. 9-12.

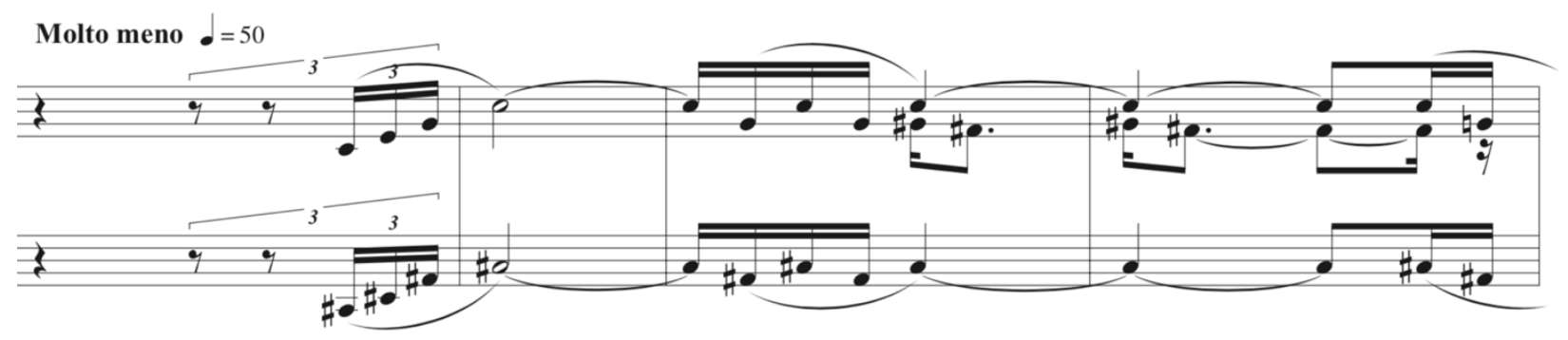

It is not surprising that Milhaud also uses multiple keys at once in each movement, as he did in his many of his other piano compositions. In Tijuca, for instance, the melody is comprised of two main voices, each starting in a different key, with a persistent conflict between major and minor that also increases tension (see Example 4.9). This technique appears almost everywhere in this work and plays the role of creating a rich and sonorous mood in addition to the tension. Milhaud uses bitonality/polytonality not only in two voices, but also in three voices, in movements such as Copacabana. The second theme of this piece appears with three voices at $\mathrm{m}$. 21; here, the top and the bottom lines share $\mathrm{G}$ major, whereas the middle line uses B major (see Example 4.10). 
Example 4.9 Darius Milhaud, Saudades do Brasil, Tijuca, mm. 1-9.
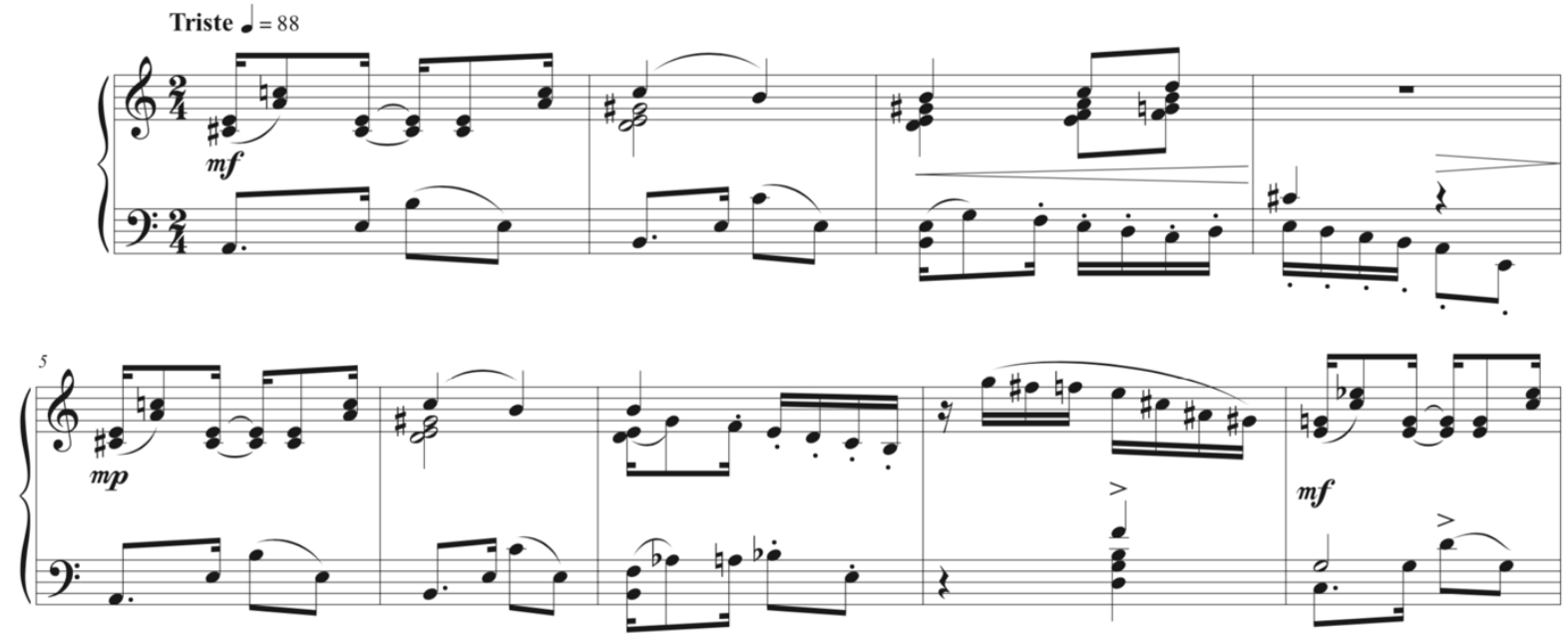

Example 4.10 Darius Milhaud, Saudades do Brasil, Copacabana, mm. 21-26.

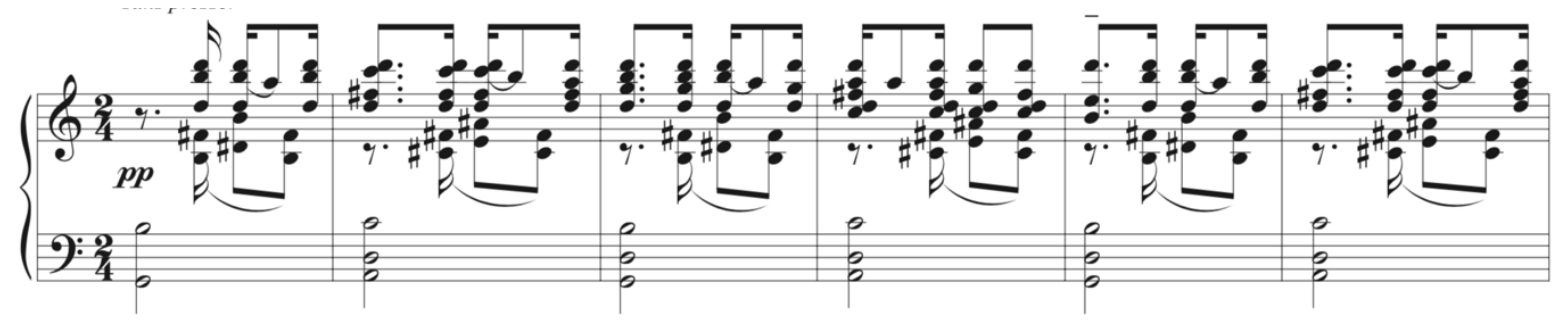


The most innovative compositional technique is the exchange of harmonies that happens in Ipanema. This piece begins with intense expanded chords in both hands and the exchange of harmonies between right hand and left hand appears throughout this movement. In mm. 1-20, for example, F major and E-flat minor chords change hands every two bars (see Example 4.11).

Example 4.11 Darius Milhaud, Saudades do Brasil, Ipanema, mm. 1-5.

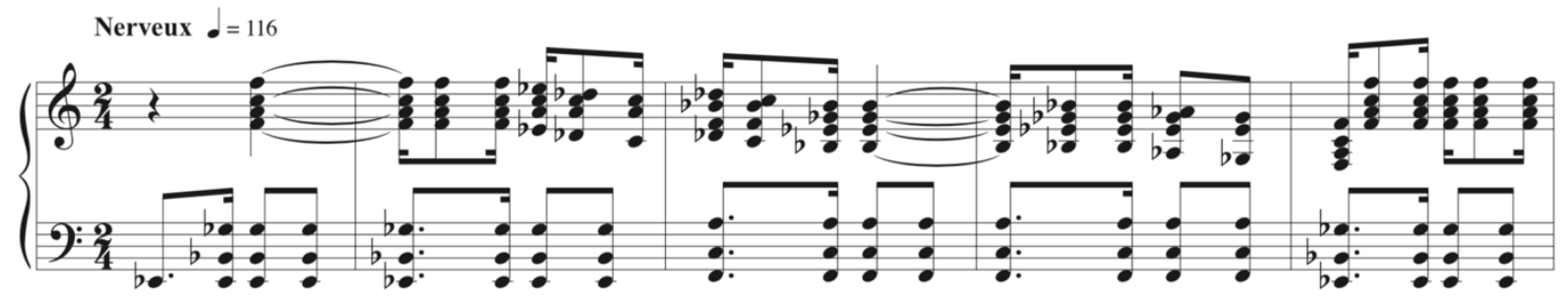

Milhaud primarily uses two kinds of accompaniment with the melody lines. The main melodies of several movements (Sorocaba, Botafoga, Leme, Copacabana, Corcovado, and Paineras) proceed horizontally, accompanied by ostinato bass figures. In contrast, either bichords or polychords are primarily used to support melody lines in a few movements, including Ipanema, Sumare, and Laranjeiras. The remaining three movements, Gavea, Tijuca, and Paysandu, reveal a combination of both methods. The chords themselves often do not provide functional harmonies, but serve to create sonorities and provide a different characteristic sound for each piece. Examples 4.12, 4.13, and 4.14 show an example of each group. 
Example 4.12. Darius Milhaud, Saudades do Brasil, Botafoga, mm. 1-4.

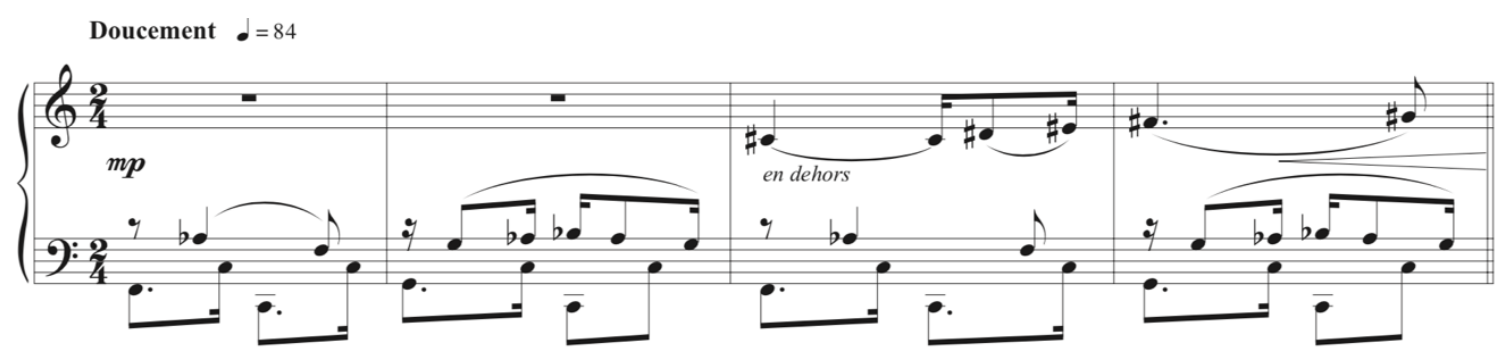

Example 4.13. Darius Milhaud, Saudades do Brasil, Laranjeiras, mm. 1-4.

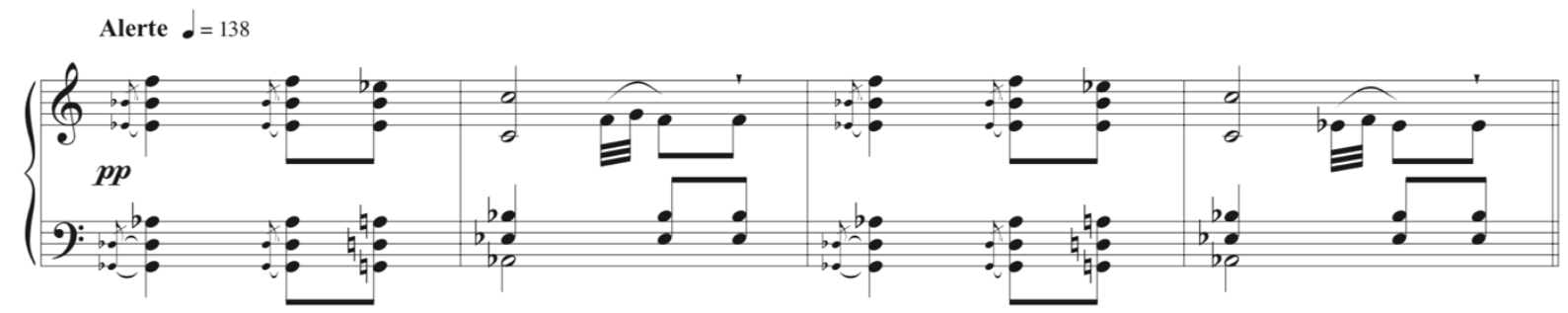

Example 4.14. Darius Milhaud, Saudades do Brasil, Paysandu, mm. 1-4.

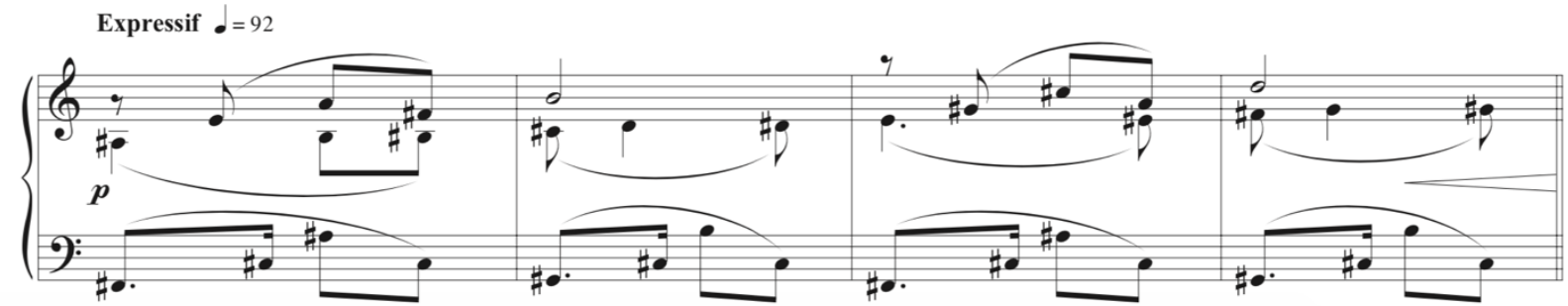


Milhaud rarely incorporates Brazilian traditional melodies; instead, he recalls the rhythms and sounds of the music he heard during his stay. ${ }^{82}$ All the movements except two (Leme and Laranjeiras) use tango and habanera rhythms. These two popular Brazilian rhythms recur in the left hand as an ostinato in many of the movements to support the melody lines in the upper part. Occasionally these two types of rhythms appear in the right hand as well. For example, Sumare uses tango rhythm in both hands at m. 29 (see Example 4.15)

Example 4.15. Darius Milhaud, Saudades do Brasil, Sumare, mm. 29-34.

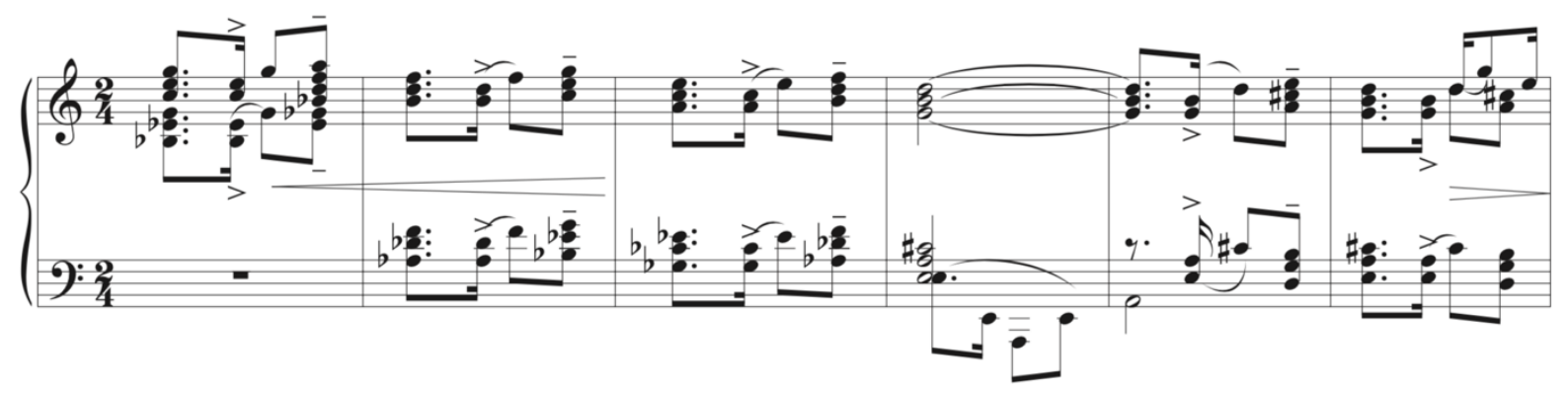

Milhaud often combines the basic dance rhythms in various ways. For example, he chooses tango rhythms for the bass part at the beginning of Corcovado, but introduces the habanera pattern at measure 3 . At $\mathrm{m}$. 20 , he modifies the rhythm so that the two types are combined (see Example 4.16). These examples of Brazilian conventional rhythms demonstrate a significant way that Milhaud chooses to flavor the music. Of particular interest is that this technique is not typical in his other piano compositions from this time, nor is it typical of the other $20^{\text {th }}$ century composers in France. His use of ethnic rhythms in these pieces marks an important distinction between this set and his other pieces.

\footnotetext{
${ }^{82}$ Stone Jason A., "Brazilian influences on Milhaud's Scaramouche, op. 165," (M.M. thesis, University of California at Irvine, 1999).
} 
Example 4.16. Darius Milhaud, Saudades do Brasil, Corcovado, mm. 1-4, 20-24.
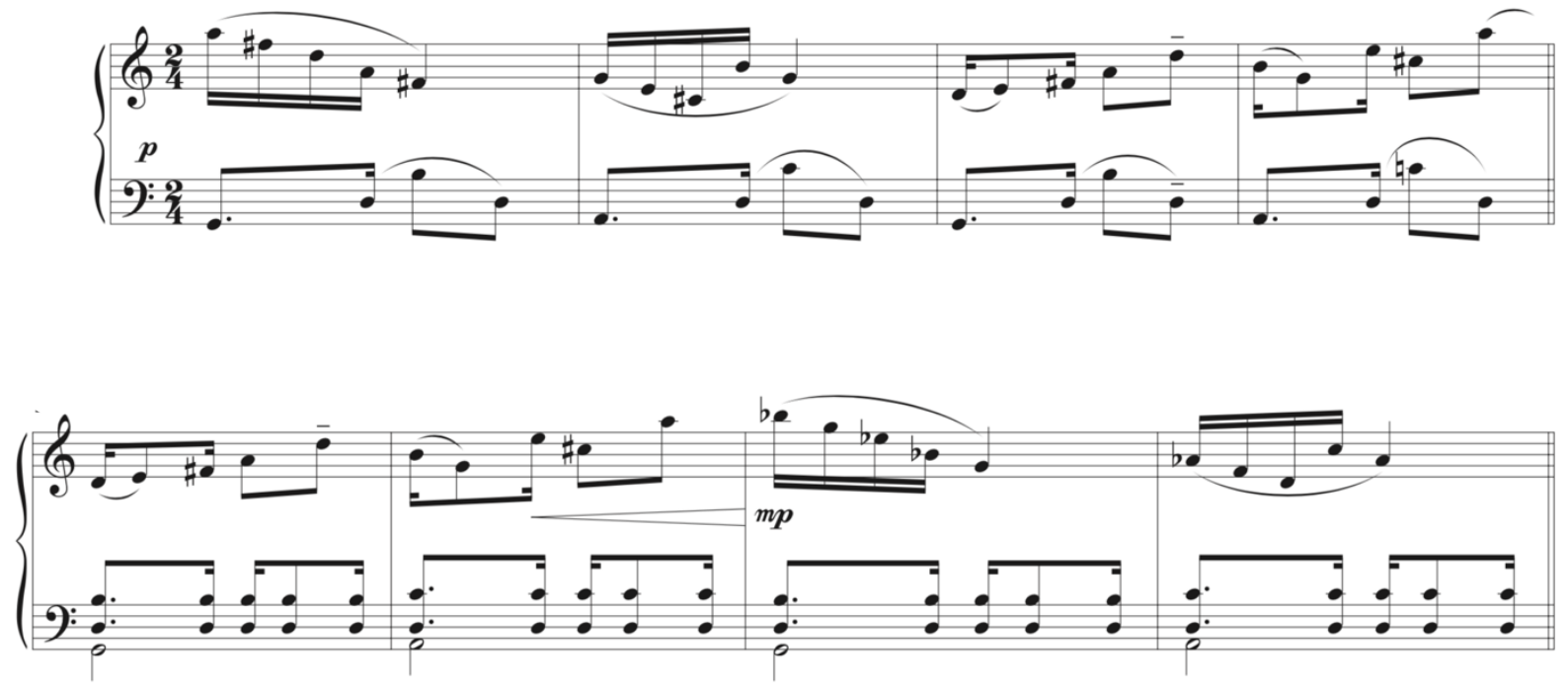

From a pianistic perspective, it is important to practice these 12 movements with individual concepts and interpretations, because they reveal different styles. For example, the performer needs to needs to be especially sensitive to clean pedaling for the simple melodic figures in Sorocaba (see Example 4.7 above). Occasionally special technical challenges await the pianist. For example, the successive thirds in Leme and Gavea, along with some passages which use fourths in other movements demand extra practice to produce even and smoothly flowing sounds. Moreover, continuing thick chords appear at several places (see Example 4.11 above); maintaining a relaxed and flexible arm can help in performing them. However, the most important requirement is that the performer understand each piece's style characteristics.

These 12 movements were composed in 1920, when Impressionistic music was popular, in addition to the vestiges of Romanticism. Milhaud shows through this work his employment of foreign materials to compose each movement based on his own musical language. He also employs a large range of dynamic effects, providing contrast and helping to make climactic 
moments in the piece. His sudden modulations and texture changes are distinctive characteristics of this piece, often conveying abrupt changes of mood.

In these colorful dances, we find traditional forms and a blend of Neoclassic and Romantic style elements, all deeply infused with Latin influences and skillfully combined in Milhaud's personal ways. 


\section{Brasileira: 3rd movement of Scaramouche Suite, op. 165b}

Scaramouche, for two pianos, was composed in 1937. The title refers to the name of a stock clown character from the $16^{\text {th }}$ century's commedia dell'arte. This work is comprised of three movements: I. Vif, II. Modéré, III. Brasileira. ${ }^{83}$ Milhaud recycled two of the sections from his incidental music to Le medécin volant to form the outer movements of the suite; for the slower middle movement, he extracted a piece he had written for Jules Superville's 1936 play Bolivar. ${ }^{84}$ On YouTube there is a recording of Milhaud himself performing Scaramouche. ${ }^{85}$

Milhaud also arranged this work, originally composed for two pianos, for alto saxophone and orchestra (1940), and for clarinet and orchestra (1941). After his three arrangements were published, various composers have also rearranged parts of this work for diverse instrumental combinations, such as Scaramouche for alto saxophone and wind quintet, and Scaramouche for guitar trio. ${ }^{86}$

This piano-duo piece has been enduringly popular from the beginning. This is true despite the fact that, in 1943, the work was banned in France during World War II because of Milhaud's Jewish religion. For that reason, Milhaud gave his name as Hamid-al-usurid, and introduced Scaramouche as Mousarechac. ${ }^{87}$

\footnotetext{
${ }^{83}$ Rupert, The piano music of Darius Milhaud: A survey, 99.

84 "Darius Milhaud," allmusic, accessed Nov 4, 2019, https://www.allmusic.com/composition/scaramouche-3-suitefor-2-pianos-op-165b-mc0002364142.

85 “Milhaud and Meyer play Milhaud "Scaramouche," YouTube, accessed Nov 8, 2019, https://www.youtube.com/watch?reload=9\&v=PwvQwfq1A3c.

${ }^{86}$ Lee, A Study on the Discriminative Elements, 23.

${ }^{87}$ Liang, An Analysis of Various Characteristics, 18.
} 
Milhaud writes this amusing story in his autobiography:

\begin{abstract}
Also at this time I composed a piano work which gave me enormous trouble. It was a suite for two pianos, to be played by Ida Jankelevitch and Marcelle Meyer. I took some passages from two sets of incidental music for the stage, and called the mixture Scaramouche. At once publisher Deiss offered to publish it. I advised him against it, saying that no one would want to buy it. But he was an original character who only published works that he liked. He happened to like Scaramouche and insisted on having his way. In the event he was right, for while sales of printed music were everywhere encountering difficulties, several printings were made, and Diess took a special delight in informing me: 'The Americans are asking for 500 copies and 1000 are being asked for elsewhere. ${ }^{98}$
\end{abstract}

Briefly, the first movement, an ABA' form, is an exciting and energetic work based on a strong pulse and a recurring sixteenth-note pattern; conventional Brazilian rhythms appear. The second movement is also in three sections (ABA') and features canon, frequent dotted rhythms, ostinato patterns, and complicated rhythms. The last movement, Brasileira, draws from Brazilian musical features and Milhaud marks it "Mouvement de Samba." The remainder of this chapter discusses this third movement, through musical examples and analysis.

${ }^{88}$ Milhaud, My Happy Life, 190. 
Table 4.1. Darius Milhaud, Brasileira, Outline.

\begin{tabular}{|c|c|c|c|}
\hline Parts & Motive & Measures & Key \\
\hline A & $\begin{array}{c}\text { Introduction } \\
\text { a } \\
\text { a' } \\
\text { a }\end{array}$ & $\begin{array}{c}1-2 \\
3-10 \\
11-18 \\
19-26\end{array}$ & F Major \\
\hline B & $\begin{array}{c}b \\
b\end{array}$ & $\begin{array}{l}27-30 \\
31-38\end{array}$ & C Major \\
\hline $\mathrm{C}$ & $\begin{array}{c}\mathrm{c} \\
\mathrm{c} \\
\text { Transition } \\
\text { d } \\
\text { c' }\end{array}$ & $\begin{array}{l}39-46 \\
47-54 \\
55-57 \\
58-73 \\
74-89\end{array}$ & $\begin{array}{l}\text { A Major } \\
\text { F Major }\end{array}$ \\
\hline$A^{\prime}$ & $\begin{array}{c}\text { Transition } \\
\text { a } \\
\text { a' } \\
\text { a }\end{array}$ & $\begin{array}{c}90-92 \\
93-100 \\
101-18 \\
109-116\end{array}$ & F Major \\
\hline
\end{tabular}


Brasileira appears in ABCA' form, as outlined above (see Table 4.1) and Milhaud uses four main thematic materials throughout this movement (see Example 4.17).

Example 4.17. Darius Milhaud, Brasileira, Four themes.

1st Theme, mm. 3-17

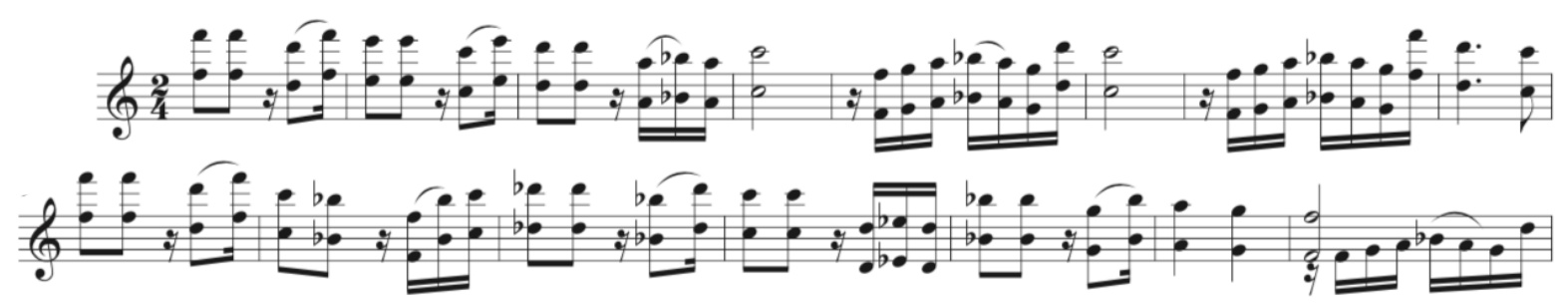

2nd Theme, mm. 27-30

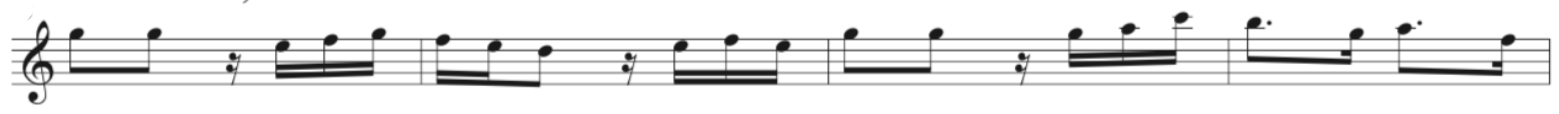

3rd Theme, mm. 39-46
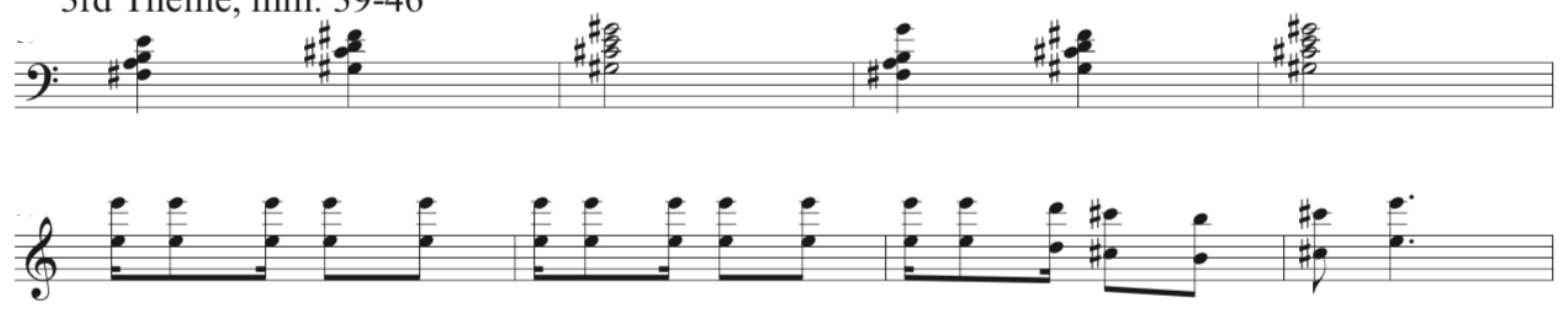

4th Theme, mm. 58-61

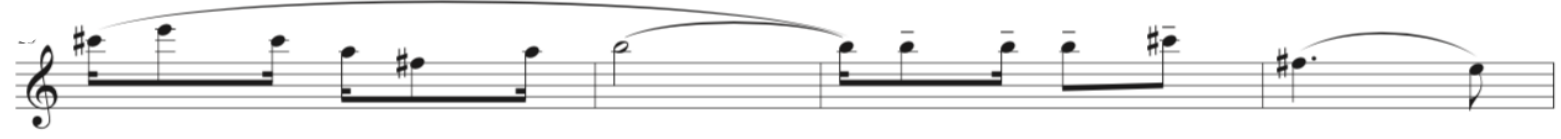


Motive a, in F major, commences in m. 3 after two measures of introduction. In Part A, this motive repeats two more times in varied forms. Next, Part B consists of two sets of motive b, in C major. Interestingly, various writers express conflicting views about the form of the piece after this point. In the D.M.A. dissertation "A Study on the Discriminative Elements in Scaramouche of Darius Milhaud" by Kwang Bok Lee, she divides this movement into ABA' form. ${ }^{89}$ Cho-Long Ahn also sees it similarly. ${ }^{90}$ On the other hand, Jason A. Stone refers to this movement as a theme and variation form..$^{91}$ The diversity of views is fascinating!

From my perspective, it feels right to call it a four-part form, $\mathrm{ABCA}^{\prime}$, in part because of the four themes shown in Example 4.15 above. Parts B and C present differing motives ( $b$ and $\mathrm{c} / \mathrm{d}$ ), which to me is a convincing reason for dividing them into different sections. Furthermore, Part $\mathrm{C}$ begins in A major, which is a new key. In part C, Milhaud uses an eight-bar motive (c), which alternates between the first piano and the second piano; then we see a transition for three measures, leading to the new motive d. After one more appearance of motive $\mathrm{c}$ in the new key, F major, three measures of transition are followed by a return to motive a, which is repeated three times to finish the piece.

As Milhaud indicates Mouv't de Samba at the beginning of the movement, this piece is based on the Brazilian samba's traditional dance rhythm. In addition to that, the melodic motives reflect the musical taste of Brazil.

\footnotetext{
${ }^{89}$ Lee, A Study on the Discriminative, 24.

${ }^{90}$ Cho-Long Ahn, “Analysis on the Two-piano for $\lceil$ Scaramouche」 by Darius Milhaud," (M.M. thesis, Youngnam University, 2003), 36.

${ }^{91}$ Stone, Brazilian influences on Milhaud's Scaramouche, 30.
} 
The piece opens with a two-bar introduction, with syncopated rhythms in the first piano and successive sixteenth-note figures in the second piano. Through mm. 3-26, Milhaud uses simple and recurring rhythmic patterns which appear in two different styles. One piano plays the melody in octaves in the right hand and vertical chord figures in syncopated rhythms in the left hand, while the other piano continues playing repeated sixteenth notes. The ever-changing division of the sixteenth notes between the hands is a method that Milhaud learned in Rio de Janeiro. ${ }^{92}$ During the three repetitions of motive 'a,' the first piano takes a leading role, while the second piano provides the accompaniment. In particular, the sixteenth-note pattern in the second piano changes the harmony every two measures (I-V7 in F major) except transitional passages in mm. 11-18, quasi ostinato (see Example 4.18). Part A, with these conventional harmonies and textures and a wide range in dynamics, finishes with a perfect authentic cadence at m. 26.

${ }^{92}$ Ahn, Analysis on the Two-piano, 40. 
Example 4.18. Darius Milhaud, Brasileira, Three primary rhythm types in Part A.
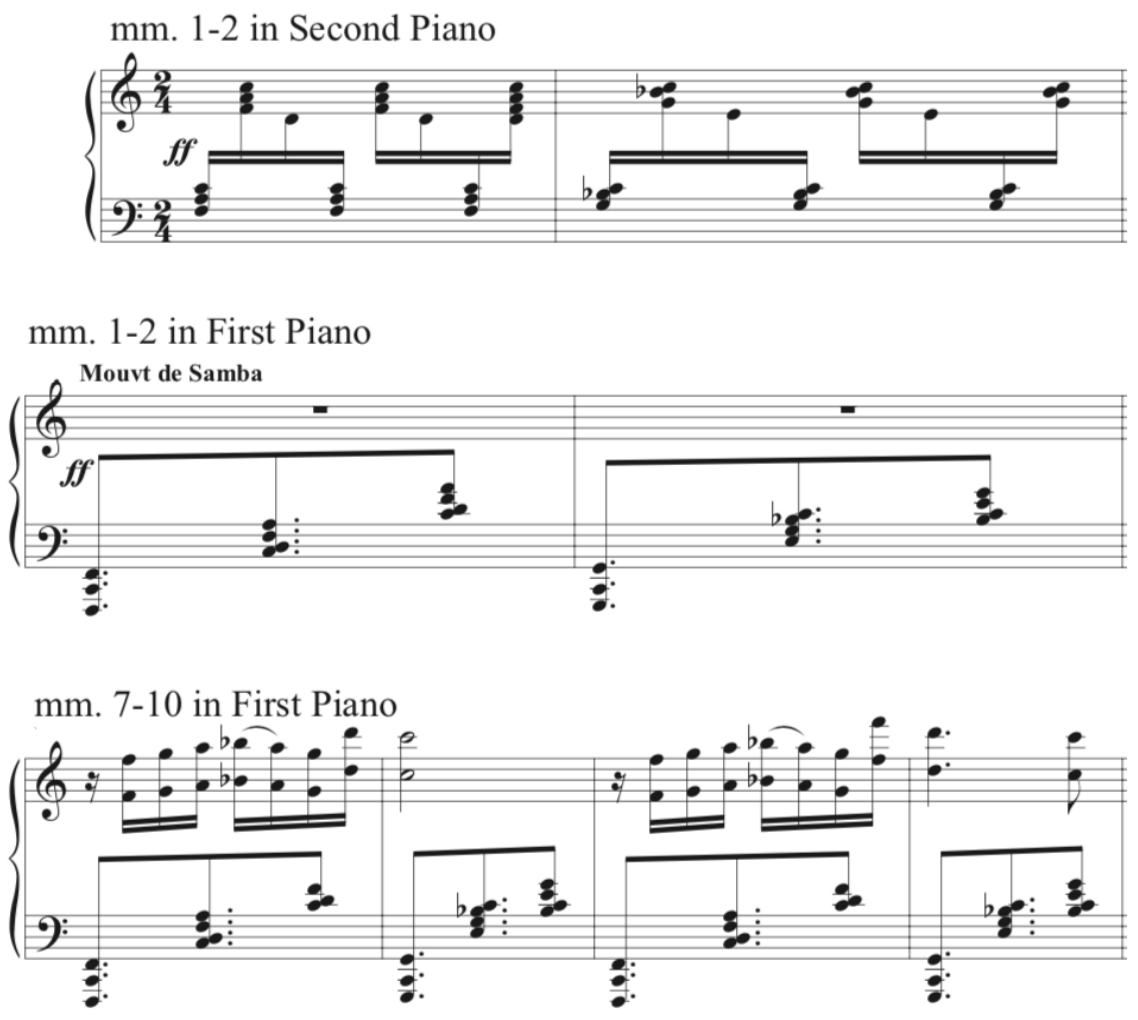

mm. 3-6 in First Piano

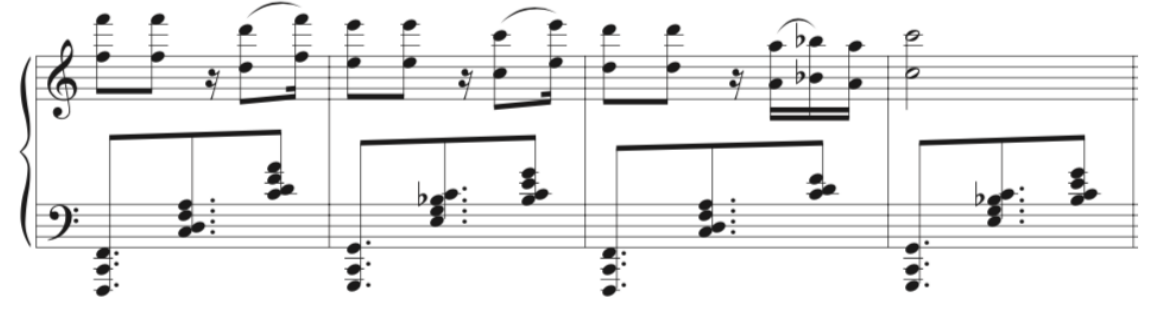


Part B, which consists of twelve bars, presents two sets of motive b in C major. Milhaud gives the melody lines to the second piano this time, while the first piano takes over the recurring sixteenth-note passage throughout the section. In addition to the use of a different motive and key in this section, the two big chords in the last bar of this part convey a concluding effect. Instead of using a syncopated rhythm, the first piano's accompaniment to the second piano's melodic line is based on the tango rhythm. Technically, this passage of big leaps demands speedy movements from the pianist (see Example 4.19).

Example 4.19. Darius Milhaud, Brasileira, mm. 30-33.

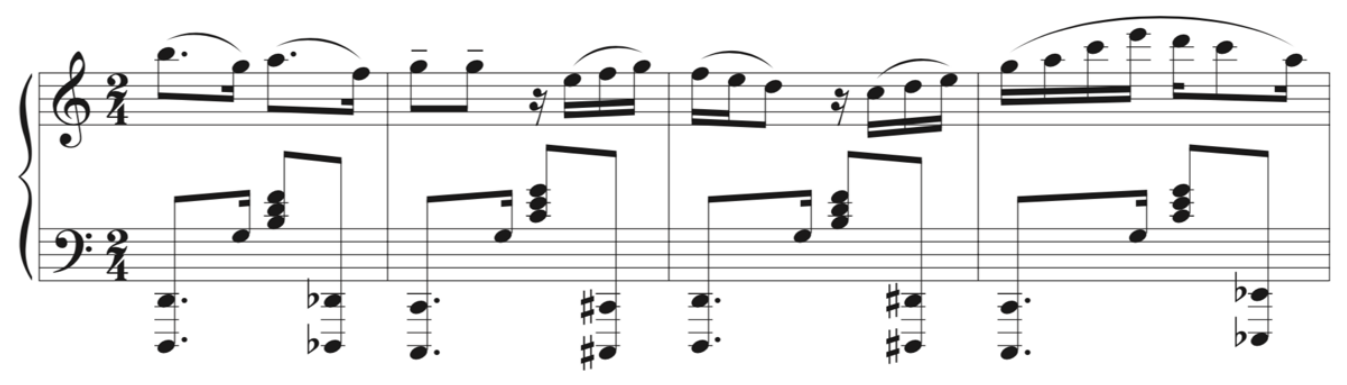

Although this movement cannot be categorized into standard forms such as five-part rondo, sonata or variations, it still reveals a distinct shape (ABCA'). While Part A is the grand opening and Part B is a repetition of Part A with a different motive, Part C is a developmental section which shows a variety of brilliant pianistic techniques. In Part $C$ the composer offers new rhythmic patterns which require virtuosity of the pianist. These rhythmic patterns are divided into three types (see Example 4.20), of which rhythm type 3 implies varied scale patterns and appears throughout part C. 
Example 4.20. Darius Milhaud, Brasileira, Three primary rhythm types in Part C.
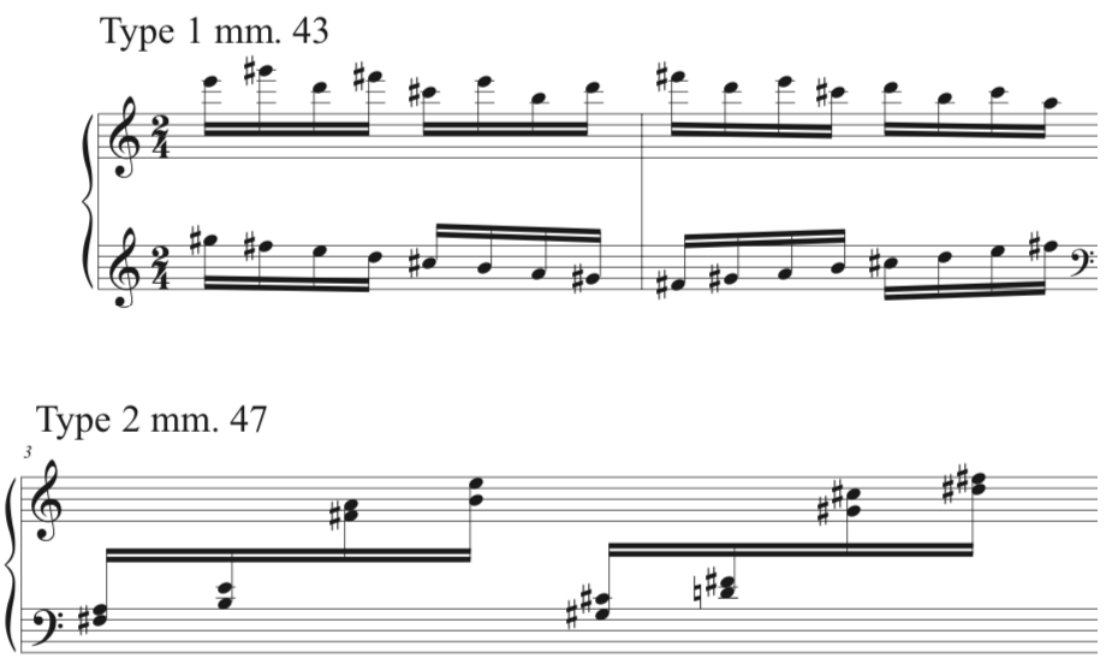

Type $3 \mathrm{~mm} .58$

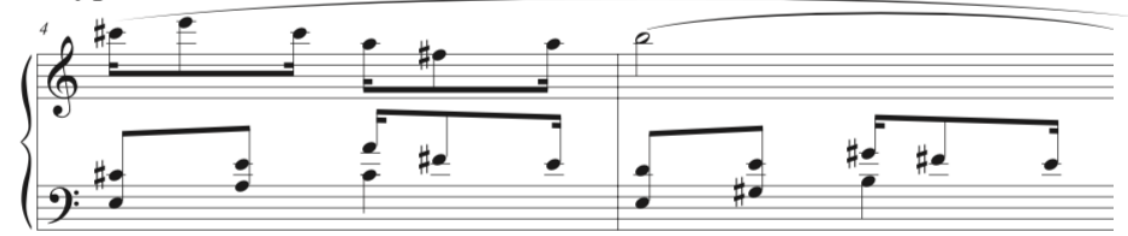

Part A' is nearly identical to Part A in key, motive, and number of measures. The dynamics do differ, in that part A' reaches fff towards the climactic ending, while A only uses ff.

Milhaud unifies the whole piece by using similar motives throughout. As the new material emerges in each new part, fresh feeling and tension come along. The return of the first motive at the end gives the feeling of being home.

The most characteristic feature compositionally in this movement is combining the textures of the first and second piano parts to create the precise harmony. Milhaud adopts prominent vertical chords for one piano, and horizontal flowing figures for the other. This method is applied from the beginning to the end. 
According to Stone,${ }^{93}$ the most important job for the performer is to recreate the taste of Brazil that the composer has supplied. Many of the syncopated dancelike figures and lively dotted rhythms demand that the performers deliver an accurate pulse. Three-against-four passages, which appear in several places, also need extra attention from the players. These challenges, within the energetic drive of the samba dance, require an understanding of complicated rhythms. There are technical obstacles, too, as the first piano player in section A needs strong octaves, while the rapid sixteenth-note passages require quick gestures and relaxed fingers.

Like many of Milhaud's other compositions that employ diverse stylistic languages, Scaramouche also displays its own unique style combination of European classical-music idioms with Latin influence. Joining the spirit of Brazilian dance is essential for performing this movement.

${ }^{93}$ Stone, Brazilian influences on Milhaud's Scaramouche, 30-33. 


\section{Brazilian Influences on Milhaud}

What we call Western art music was introduced into Brazil by European monks in the $16^{\text {th }}$ century. Keyboard works began to spread after the first organs were built in Pernambuco and Minas Gerais. The first colonial composition (1759) was written by Caetano de Mello de Jesus, who was a Brazilian priest, conductor, composer and music theorist. In the late $18^{\text {th }}$ century to early $19^{\text {th }}$ century, Minas Gerais was the social, artistic, and commercial center of the country and opera was the most popular Classical style in Brazil. The most important composer was Antônio Carlos Gomes. His composition from 1863, Joana de Flandres, was notable because it added a unique Brazilian flavor to the current European trends. Opera in Brazil was very popular until the middle of the $20^{\text {th }}$ century. While opera bloomed, Brazilian keyboard works came into their own in the later $19^{\text {th }}$ century to early $20^{\text {th }}$ century. Luciano Gallet $(1893-1931)$ and Alexandre Levy (1864-1892) are two representative composers who created the basis of a national movement during this period. This trend was continued by Heitor Villa-Lobos (18871959), a major figure who composed in various genres for solo piano, including many pieces grouped in series. Marlos Nobre (b. 1939), who studied with Ginastera, Messiaen, Malipiero, and Dallapiccola, has also achieved international recognition. ${ }^{94}$

Within the brief history of Brazilian art music for the piano, Milhaud spent two years composing his works in Brazil; he also had opportunity to hear music by local composers such as Glauco Velasquez and Ernesto Nazareth. ${ }^{95}$

\footnotetext{
94 “Art Music,” Encyclopedia, accessed Nov 4, 2019, https://www.encyclopedia.com/humanities/encyclopediasalmanacs-transcripts-and-maps/art-music.

95 Ibid.
} 
When Milhaud reached Rio in 1917, there was a movement by Brazilian composers who favored creating authentically Brazilian music, with less influence from European traditions. In this sense, the traditional folk materials were major sources of inspiration in the composers' works. While in Brazil, Milhaud truly was influenced by its cultures, popular music, and natures, though it is not known if he was inspired by any specific composers aside from Ernesto Nazareth.

Ernesto Nazareth was one of most advanced composers in Brazil, as Milhaud describes him in his autobiography, My Happy Life: ${ }^{96}$

One of the best composers of Brazilian music with subtlety, Nazareth, used to play the piano at the door of a cinema in the Avenida Rio Branco. His elusive, mournful, liquid way of playing also gave me deeper insight into the Brazilian soul.

Odeon by Nazareth presents Latin elements such as maxixe, ${ }^{97}$ choro, ${ }^{98}$ polka and even the Cuban habanera. ${ }^{99}$ Nazareth refers to his tango-based compositions as "Tango Brasileiro (Brazilian Tango)," often showing the typical harmonies and structures of the European polka (see Example 4.21).

\footnotetext{
${ }^{96}$ Milhaud, My Happy Life, 71.

${ }^{97}$ Maxixe: Brazilian urban popular dance with European dance figures such as the polka and mazurka, incorporating Brazilian elements.

${ }^{98}$ Choro: Samba-style or bossa-nova rhythms played on a guitar or other fretted stringed instruments, usually consisting of three parts.

${ }^{99}$ Andree-Ann Deschenes, "A survey of classical piano literature in Cuba \& Brazil; the music of Cervantes, Lecuona and Nazareth," (M.M. thesis, California State University, Los Angeles, 2014), 44.
} 
Example 4.21. Typical dance rhythms in Nazareth's music.
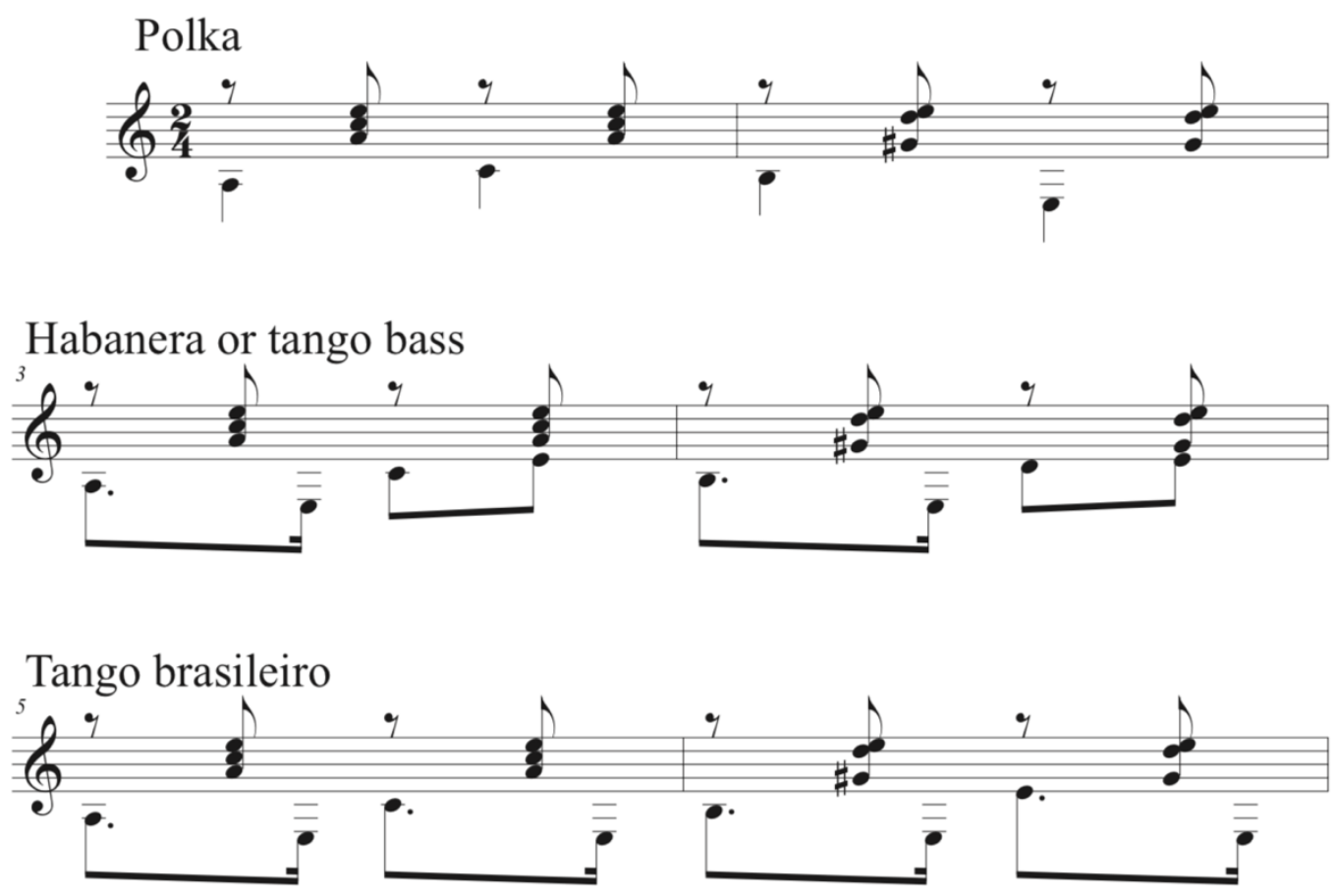

According to Painting, it is certain that Nazareth's melodies are directly quoted in some of Milhaud's Brazilian pieces, including Saudades do Brasil and the Le Bœuf sur le toit, op. 58; the latter includes almost 30 Brazilian folk tunes. Along with Milhaud, Villa-Lobos, one of the most prominent pianists and composers in Brazil, also praised Nazareth: "His playing helped me better understand the Brazilian soul." Nazareth was extremely popular in Brazil during his lifetime; unfortunately, though, he was almost unknown anywhere else. ${ }^{100}$

Alexandre Levy (1864-1892) is a fine example of a composer who combined European formal structures with elements of Brazilian folk music. Like other Brazilian composers, including Nazareth, he also wrote a piece entitled Tango Brasileiro (1890), with typical Brazilian

\footnotetext{
${ }^{100}$ Kevin Painting, "Ernest Nazareth : the incarnation of the Brazilian Soul," Settling Scores, Nov 4, 2019, http://berggasse19.org/ernesto-nazareth-the-incarnation-of-the-brazilian-soul/.
} 
traditional rhythms. Despite the fact that he was recognized as a nationalistic composer in his generation, a fair number of his piano compositions are characterized in European style. The importance of Levy's work as a composer consisted of the fact that a respected Brazilian musician with excellent European training systematically began to employ Brazilian folk and popular music in his compositions at a time when Brazilian musicians were attempting to break the bonds of European artistic domination. ${ }^{101}$ That said, his most interesting piece is called Schumanniana, op. 16, in an obvious direct reference to Robert Schumann's Kreisleriana, which is also op. 16. Both pieces contain eight movements and are similarly composed in a Romantic musical language (see Example 4.22).

101 David P Appleby, “Levy, Alexandre (1864-1892)," Encyclopedia of Latin American History and Culture 4, 2nd ed., (2008): 181-182. 
Example 4.22. Alexandre Levy, Schumanniana, op.16, mm. 1-4.
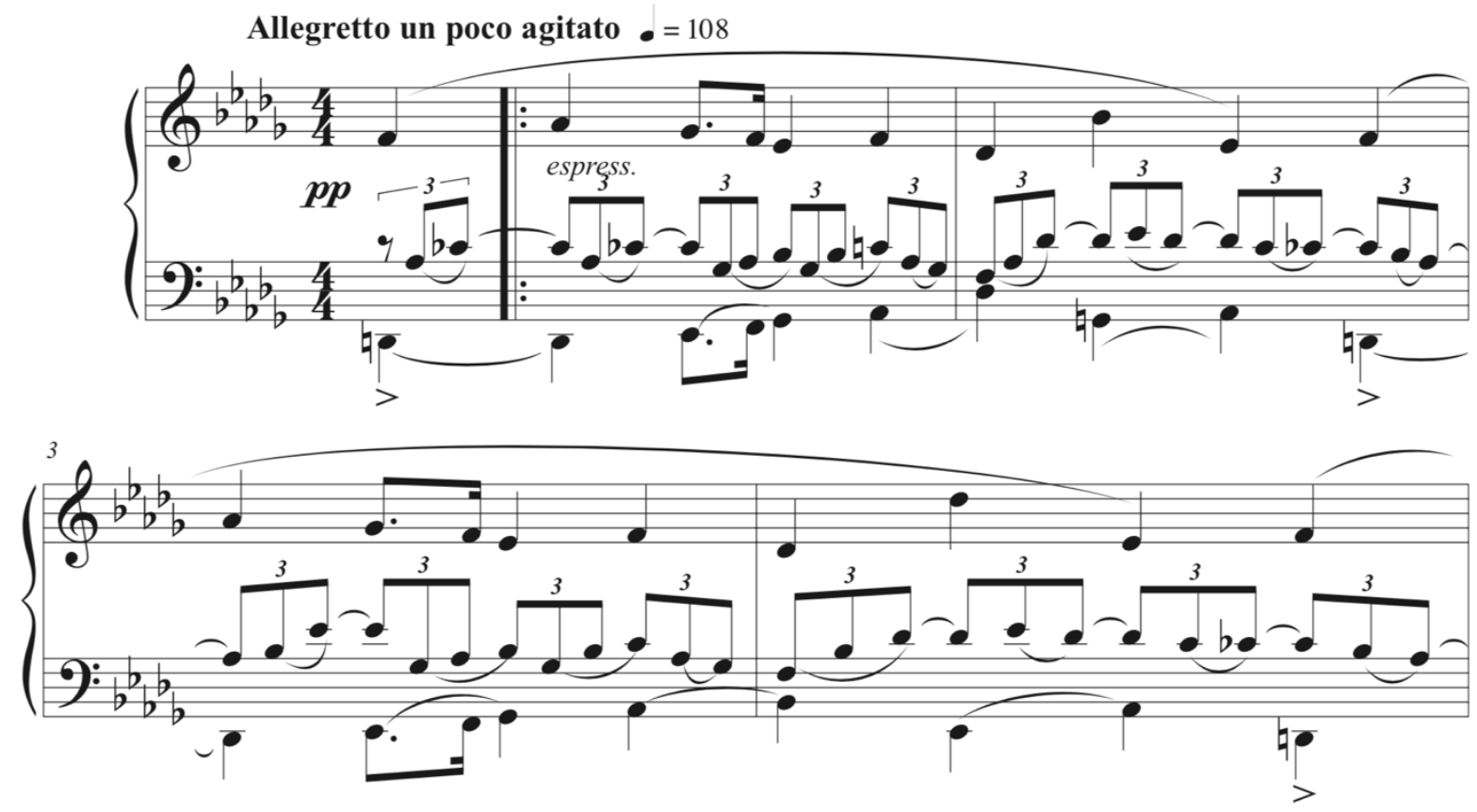

In addition to his Schumanniana, op.16, Levy's piano compositions such as Allegro Appassionato, op. 14; Fantasia Brilhante; and Scherzo, op. 7, also employ musical techniques similar to those of European composers such as Chopin, Schumann, and Brahms.

Luciano Gallet (1893-1931), who studied with Milhaud, also shows his European musical language through his early piano compositions such as Rapsódia sertaneja and Nhô Chico. But later contact with Mário de Andrade (1893-1945) resulted in serious studies of Brazilian popular and folk music. Moreover, some of his music, such as Hieroglifo, is adventurous in using some avant-garde techniques. ${ }^{102}$

\footnotetext{
102 David P. Appleby, "Gallet, Luciano (1893-1931)," Encyclopedia of Latin American History and Culture 3, 2nd ed., (2008): 356.
} 
Glauco Velásquez (1884-1914) was another prominent Brazilian composer during the late $19^{\text {th }}$ and early $20^{\text {th }}$ centuries. Unlike most of his contemporaries who adhered either to European Romantic or to Brazilian nationalist style, he followed the French school of Franck and Debussy for his later works, thus breaking away from both the prevailing German Romanticism and also from Brazilian tradition. ${ }^{103} \mathrm{He}$ used an inventive language resembling that of the Neoclassic composers including Satie. In particular, his late pieces demonstrate knowledge of Satie's techniques, revealing atonal figures, polytonality, and contrapuntal passages. ${ }^{104}$ Milhaud explained his own first impression of Glauco Velásquez's music: ${ }^{105}$

Before I left Paris, I had met Andre Messager, back from Brazil, who had recommended me to get to know the music of Glauco Velasquez. When I had done so, I was struck by its resemblance, both structurally and in inspiration, with that of Guillaume Lekeu. ${ }^{106}$

During Milhaud's two-year stay in Brazil, Brazilian art music mostly was led by nationalist composers with their folk-influenced music. They used Cuban habanera rhythms and melodies from Brazilian folk song, along with maxixe and choro, which had evolved from habanera or tango rhythms. Brazilian art music became more popular especially after the Modern Art Week was held in 1922 at São Paulo's Teatro Municipal. This was a cultural festival featuring a three-day series of concerts, readings, lectures, dances, and exhibitions of art. The

\footnotetext{
103 Gerard Béhague, "Velásquez, Glauco," Grove Music Online, accessed 4 Aug, 2019, https://www.oxfordmusiconline.com/grovemusic/view/10.1093/gmo/9781561592630.001.0001/omo9781561592630-e-0000029129.

104 “Glauco Velásquez,” Wikipedia, accessed Nov 5, 2019, https://pt.wikipedia.org/wiki/Glauco_Velásquez.

${ }^{105}$ Milhaud, My Happy Life, 71.

${ }^{106}$ Guillaume Lekeu: Belgian composer influenced by the French school of Franck and Satie in the late nineteenth century.
} 
people that produced and participated in the festival were self-consciously declaring their cultural independence from traditional forms and styles, and announcing the arrival of Brazilian modernism. ${ }^{107}$ From this event, Villa-Lobos was discovered as a new nationalist-style composer and his mixture of conventional art music and vernacular music became a new trend in Brazilian Classical music.

On the other hand, a fair number of composers were strongly under the influence of European tradition. Milhaud was surprised when hearing Glauco Velasquez' music, which he felt evokes that of Guillaume Lekeu, who was trying to employ Neoclassic styles; although Velasquez was a Brazilian composer, he still followed European tradition. Many Brazilian composers, like Alexandre Levy in his piano compositions such as Impromptu-Caprice, Mazurka and Fantasia Brilhante, not only applied European compositional styles but also borrowed European genres and structures.

In conclusion, Brazilian art-music composers in the early $20^{\text {th }}$ century were open to many cultural influences in addition to their own local styles. Music can be an excellent way to show both a proud sense of national identity and also a broad historical context.

\footnotetext{
${ }^{107}$ Mary Luciana Lombardi, "Modern Art Week," Encyclopedia of Latin American History and Culture 4, 647, accessed August 5, 2019, http://link.galegroup.com.ezproxy.lib.ucalgary.ca/apps/doc/CX3078903696/WHIC?u=ucalgary\&sid=WHIC\&xid=1 28d96b6.
} 


\section{Chapter 5}

\section{Conclusion}

Gottschalk and Milhaud were significant composers living in the United States and France, respectively, in the late $19^{\text {th }}$ and early $20^{\text {th }}$ centuries. In their music, they both show nationalistic elements at first, but they both changed their compositional directions when influenced by other personalities, by audiences' tastes, or especially by geographical changes. The common thing between them is that some of their piano music was influenced by the Latin countries they visited.

In fact, their piano compositions written in their own countries vary in style, form, texture, and rhythms. They sometimes adopted styles and materials from other personalities, but mostly established their own characteristics.

Their compositions that were influenced by Latin American cultures show different methods of combining two different musical languages. In Souvenir de Porto Rico and in Souvenir de la Havane, Gottschalk applied Romantic musical figurations in conjunction with the popular Cuban contradanza form. Similarly, in Saudades do Brasil and in Brasileira (the third movement of the Scaramouche suite), Milhaud employs bitonality, which was frequently a stylistic feature for French composers in the late $19^{\text {th }}$ and early $20^{\text {th }}$ centuries; however, in both

pieces, his use of typical Brazilian traditional rhythms reveals how strongly he was influenced by his stay in that country.

Gottschalk lived for a significant time in the West Indies, whereas Milhaud spent just two years in Brazil. No matter how long, their travels to foreign countries and their interactions with local composers were important for them, especially during their historical time, when 
transportation and access to media were certainly not as simple as they are today. Even during that time, music could connect and unify countries. It is vastly easier now to approach other countries' music than it was when Gottschalk and Milhaud visited their Latin host countries, because technology has helped to blur the boundaries between cultures. It is also interesting to note that many local composers in Cuba and Brazil by this time had already encountered European music traditions through visiting countries in Europe or by meeting or studying with guests from Europe in their countries.

The blending of widely differing cultures provides a context for understanding the four piano compositions discussed in this research project. As these four works were written with different cultures' idioms, it is interesting to examine how composers employ these unique musical styles in their own works; exploring their compositions in depth is an additional pleasure. This research considers not only the musical styles of Gottschalk and Milhaud, but also their intentional mixing of European and Latin musical traditions.

Study of such musical and cultural fusion is a viable and growing new discipline that is highly relevant to the modern musician and performer. The pedagogical aspects discussed throughout this research project may also encourage musicians to approach and play these pieces. I sincerely hope that this document can be a helpful resource for musicians, students, and researchers interested in learning more about multi-cultural fusion in these works for piano. 


\section{Bibliography}

Ahn, Cho-Long. "Analysis on the Two-piano for Scaramouche by Darius Milhaud.” M.M. thesis. Youngnam University, 2003.

Appleby, David P. “Levy, Alexandre (1864-1892).” Encyclopedia of Latin American History and Culture 4, 2nd ed., (2008): 181-182.

Appleby, David P. "Gallet, Luciano (1893-1931)." Encyclopedia of Latin American History and Culture 3, 2nd ed., (2008): 356.

“Art Music.” Encyclopedia. accessed Nov 4, 2019.

https://www.encyclopedia.com/humanities/encyclopedias-almanacs-transcripts-and-maps/art$\underline{\text { music. }}$

Bauer, Marion. "Darius Milhaud.” The Musical Quarterly. 28, no.

2. https://academic.oup.com/mq/article-abstract/XXVIII/2/139/1167374?redirectedFrom=fulltext (accessed Nov 3, 2019).

Béhague, Gerard. "Velásquez, Glauco." Grove Music Online. accessed 4 Aug, 2019.

https://www.oxfordmusiconline.com/grovemusic/view/10.1093/gmo/9781561592630.001.0001/ omo-9781561592630-e-0000029129.

Books, Market House. ed.. Who's Who in the Twentieth Century. Oxford: Oxford University Press. 2003, accessed July 24,

2019https://www.oxfordreference.com/view/10.1093/acref/9780192800916.001.0001/acref-

9780192800916.

Chen, Shao-Shan. "The Transformation of Caribbean Dances in Selected Piano Works of Louis Moreau Gottschalk.” D.M.A. diss.. University of Cincinnati, 2003.

Collaer, Paul. Darius Milhaud. Genève: Slatkine. 1982.

Crichton, Ronald. “Darius Milhaud.” The Musical Times. 115, no. 1578 (1974): 684-685.

“Darius Milhaud.” Allmusic. accessed Nov 4, 2019.

https://www.allmusic.com/composition/scaramouche-3-suite-for-2-pianos-op-165b$\underline{\mathrm{mc} 0002364142.1}$

Deschenes, Andree-Ann. "A survey of classical piano literature in Cuba \& Brazil; the music of Cervantes, Lecuona and Nazareth.” M.M. thesis. California State University, Los Angeles, 2014.

Douglas Shadle, "Louis Moreau Gottschalk's Pan-American Symphonic Ideal." American Music. 29, no. 4 (2011): 443-71. 
Doyle, John Godfrey. "The Piano Music of Louis Moreau Gottschalk (1829-1869).” Ph. D. thesis. New York University, 1960.

Dubal, David. “A Rousing Anthem of National Unity,” The Wall Street Journal. June 28, 2013. https://www.wsj.com/articles/SB10001424127887324577904578559401212056738/ (accessed July 15, 2019).

Erin, Maher. "Darius Milhaud in the United States, 1940-71: Transatlantic Constructions of Musical Identity." Ph.D. diss.. University of North Carolina, 2016.

Fernandez, Raul A. From Afro-Cuban Rhythms to Latin Jazz. California: University of California Press. 2006.

Gao, Dengbin. "Discussion About Darius Milhaud and His Work: Double Piano Cento Scaramouch," Cross-Cultural Communication, 11, no. 11 (2015): 63-67.

“Glauco Velásquez.” Wikipedia. accessed Nov 5, 2019. https://pt.wikipedia.org/wiki/Glauco_Velásquez.

Kelly, Barbara L. "Milhaud and the French Musical Tradition with reference to his work 191231.” Ph. D. thesis.. University of Liverpool, 1994.

Kelly, Barbara L. Tradition and Style in the Works of Darius Milhaud 1912-1939. New York: Routledge. 2016.

Lee, Kwang Bok. "A Study on the Discriminative Elements in Scaramouche of Darius Milhaud." D.M.A. diss.. Kyoungpook National University, 2015.

Lee, Patricia Taylor. "The solo piano music of Darius Milhaud with suggestions for its instructional use.” D.M.A. diss.. Temple University, 1979.

Leeuw, Ton de. Music of the Twentieth Century. Amsterdam: Amsterdam University Press. 2005.

Liang, Li. "An Analysis of Various Characteristics in Darius Milhaud's Music and Scaramouche.” M.A. thesis. Hanyang University, 2014.

Lombardi, Mary Luciana. "Modern Art Week." Encyclopedia of Latin American History and Culture 4. 647, accessed August 5, 2019.

http://link.galegroup.com.ezproxy.lib.ucalgary.ca/apps/doc/CX3078903696/WHIC?u=ucalgary\& $\underline{\text { sid=WHIC\&xid=128d96b6. }}$.

Manuel, Peter. ed.. Creolizing Contradance in the Caribbean. Philadelphia: Temple University Press. 2011. 
Mawer, Deborah. Darius Mailhaud: Modality and Structure in Music of the 1920. England: Scolar Press. 1997.

"Milhaud and Meyer play Milhaud 'Scaramouche.” YouTube. accessed Nov 8, 2019. https://www.youtube.com/watch?reload=9\&v=PwvQwfq1A3c.

Milhaud, Darius. Notes Without Music. New York: Alfred. A. Knopf. 1953.

Milhaud, Darius. My Happy Life. New York: Marion Boyars Publishers. 1995.

Murchison, Gayle. American Stravinsky. Ann Arbor: University of Michigan Press. 2012.

Musgrave, Monty. “A Wind Ensemble Adaptation and Conductor's Analysis of Selected Movements of Darius Milhaud's "Saudades Do Brazil", with an Examination of the Influences of Ernesto Nazareth.” D.M.A. diss.. Louisiana State University, 2005.

Painting, Kevin. "Ernest Nazareth : the incarnation of the Brazilian Soul." Settling Scores. Nov 4, 2019. http://berggasse19.org/ernesto-nazareth-the-incarnation-of-the-brazilian-soul/.

Panos, Steffan Eugene. "THE ROLE OF THE PIANO IN AFRO-CUBAN JAZZ.” M.M. thesis. University of California, Riverside, 2002.

Park, Jihyun. "Louis Moreau Gottschalk's Assimilation of African American Elements in Souvenir De Porto Rico.” M.M. thesis.. University of California, 2009.

Park, Miseon. "A Study on Louis Moreau Gottschalk's Early Piano Music.” D.M.A. diss.. Kookmin University, 2017.

Perez, Maria del Carmen. "Gottschalk and the Caribbean." D.M.A., diss.. University of Washington, 2001.

Pruett, Laura. "Louis Moreau Gottschalk, John Sullivan Dwight, and the Development of Musical Culture in the United States, 1853-1865.” D.M.A. diss.. The Florida State University College of Music, 2007.

Rupert, Mary Jane. “The piano music of Darius Milhaud: A survey.” D.M.A. diss.. Indiana University, 1974.

Starr, S. Frederick. Louis Moreau Gottschalk. Urbana and Chicago: University of Illinois Press. 2000 .

Stavans, Ilan ed.. Latin Music: Musicians, Genres, and Themes. ABC CLEO. 2014. Stone, Jason. "Brazilian Influences on Milhaud's "Scaramouche," op. 165." M.M. thesis. California State University, 1999. 
Stuckenschmidt, Hans Heinz. Arnold Schoenberg: His Life, World and Work. London: John Calder. 1977.

Sublette, Ned. Cuba and lts Music: From the First Drums to the Mambo. Chicago: Chicago Review Press. 2007.

Unruh, Amy Elizabeth. "Louis Moreau Gottschalk (1829-1869): The Role of Early Exposure to African-Derived Musics in Shaping an American Musical Pioneer From New Orleans." Ph.D. diss.. Kent University, 2009.

Vallée, Elisabet Omarene de. "Building Blocks of a National Style: An Examination of Topics and Gestures in Nineteenth-Century American Music as Exemplified in Scott Joplin's

"Treemonisha,." D.M.A. diss.. University of Northern Colorado, 2017.

Verbeten, Jonathan Edward. "An American in Paris: Musical Exoticism in the Solo Piano Works of Louis Moreau Gottschalk.” M.M. thesis.. University of Arkansas, 2012.

Williams, Shari Akua. "Ignacio Cervantes and his Forty Danzas in the Context of Nineteenth Century Cuban Nationalism.” M.A. thesis. University of Calgary, 2016. 